\title{
Q Q Global, regional, and national levels and causes of maternal mortality during 1990-2013: a systematic analysis for the Global Burden of Disease Study 2013
}

Nicholas J Kassebaum*, Amelia Bertozzi-Villa, Megan S Coggeshall, Katya A Shackelford, Caitlyn Steiner, Kyle R Heuton, Diego Gonzalez-Medina, Ryan Barber, Chantal Huynh, Daniel Dicker, Tara Templin, Timothy M Wolock, Ayse Abbasoglu Ozgorent, Foad Abd-Allaht, Semaw Ferede Aberat, Ibrahim Abubakart, Tom Achokit, Ademola Adelekant, Zanfina Ademit, Arsène Kouablan Adout, José C Adsuart, Emilie E Agardht, Dickens Akenat, Deena Alasfoort, Zewdie Aderaw Alemut, Rafael Alfonso-Cristanchot, Samia Alhabibt, Raghib Alit, Mazin J Al Kahbouri†, François Allat, PeterJ Allent, Mohammad A AlMazroat, Ubai Alsharift, Elena Alvarezt, Nelson Alvis-Guzmán†, Adansi A Amankwaat, Azmeraw T Amare†, Hassan Amini†, Walid Ammart, Carl A T Antoniot, Palwasha Anwarit, Johan Ärnlövt, Valentina S Arsic Arsenijevict, Ali Artamant, Majed Masoud Asadt, Rana J Asghart, Reza Assadit, Lydia S Atkinst, Alaa Badawit, Kalpana Balakrishnant, Arindam Basut, Sanjay Basut, Justin Beardsleyt, Neeraj Bedit, Tolesa Bekelet, Michelle L Bellt, Eduardo Bernabet, TarikuJ Beyenet, Zulfiqar Bhuttat, ArefBin Abdulhakt, Jed D Bloret, Berrak Bora Basarat, Dipan Boset, Nicholas Breitborde†, Rosario Cárdenast, Carlos A Castañeda-Orjuelat, Ruben Estanislao Castrot, Ferrán Catalá-Lópezt, Alanur Cavlint, Jung-Chen Changt, Xuan Che†, Costas A Christophi†, Sumeet S Chught, Massimo Cirillot, Samantha M Colquhount, Leslie Trumbull Coopert, Cyrus Coopert, luri da Costa Leitet, Lalit Dandonat, Rakhi Dandonat, Adrian Davist, Anand Dayamat, Louisa Degenhardt†, Diego De Leo†, Borja del Pozo-Cruzt, Kebede Deribet, Muluken Dessalegnt, Gabrielle A deVebert, Samath D Dharmaratne†, Uğur Dilment, Eric L Dingt, Rob E Dorrington†, Tim R Driscollt, Sergei Petrovich Ermakovt, Alireza Esteghamati†, Emerito Jose A Faraont, Farshad Farzadfart, Manuela Mendonca Felicio†, Seyed-Mohammad Fereshtehnejadt, Graça Maria Ferreira de Limat, Mohammad H Forouzanfart, Elisabeth B Françat, Lynne Gaffikin†, Ketevan Gambashidze†, Fortuné Gbètoho Gankpét, Ana C Garciat, Johanna M Geleijnset, Katherine B Gibneyt, Maurice Giroudt, Elizabeth L Glasert, Ketevan Goginashvilit, Philimon Gonat, Dinorah González-Castell + , Atsushi Gotot, Hebe N Goudat, Harish Chander Gugnanit, Rahul Gupta†, Rajeev Gupta†, Nima Hafezi-Nejad†, Randah Ribhi Hamadeh†, Mouhanad Hammamit, Graeme J Hankeyt, Hilda L Harbt, Rasmus Havmoellert, Simon I Hayt, Ileana B Heredia Pit, Hans W Hoekt, H Dean Hosgood †, Damian G Hoyt, AbdullatifHusseinit, Bulat T Idrisovt, Kaire Innost, Manami Inouet, Kathryn HJacobsent, Eiman Jahangirt, Sun Ha Jeet, Paul N Jensent, Vivekanand Jhat, Guohong Jiangt, Jost B Jonast, Knud Juelt, Edmond Kato Kabagambet, Haidong Kant, Nadim E Karamt, André Karcht, Corine Kakizi Karemat, Anil Kault, Norito Kawakamit, Konstantin Kazanjant, Dhruv S Kazit, Andrew H Kempt, Andre Pascal Kengnet, Maia Kereselidzet, Yousef Saleh Khadert, Shams Eldin Ali Hassan Khalifat, Ejaz Ahmed Khant, Young-Ho Khangt, Luke Knibbst, Yoshihiro Kokubot, Soewarta Kosent, Barthelemy Kuate Defot, Chanda Kulkarnit, Veena S Kulkarnit, G Anil Kumart, Kaushalendra Kumart, Ravi B Kumart, Gene Kwant, Taavi Lait, Ratilal Lalloot, Hilton Lamt, Van C Lansinght, Anders Larssont, Jong-Tae Leet, James Leight, Mall Leinsalut, Ricky Leungt, Xiaohong Li†, Yichong Lit, Yongmei Lit, Juan Liangt, Xiaofeng Liangt, Stephen S Limt, Hsien-Ho Lint, Steven E Lipshultzt, Shiwei Liut, Yang Liut, Belinda K Lloydt, Stephanie J Londont, Paulo A Lotufot, Jixiang Mat, Stefan Mat, Vasco Manuel Pedro Machadot, Nana Kwaku Mainoot, Marek Majdant, Christopher Chabila Mapomat, Wagner Marcenest, Melvin Barrientos Marzant, Amanda J Mason-Jonest, Man Mohan Mehndirattat, Fabiola Mejia-Rodriguezt, Ziad A Memisht, Walter Mendozat, Ted R Millert, Edward J Millst, Ali H Mokdadt, Glen Liddell Molat, Lorenzo Monasta†, Jonathan de la Cruz Monist, Julio Cesar Montañez Hernandez†, Ami R Moore†, Maziar Moradi-Lakeh†, Rintaro Mori†, Ulrich O Muellert, Mitsuru Mukaigawarat, Aliya Naheedt, Kovin S Naidoot, Devina Nandt, Vinay Nangiat, Denis Nasht, Chakib Nejjarit, Robert G Nelsont, Sudan Prasad Neupanet, Charles R Newtont, Marie Ngt, MarkJ Nieuwenhuijsent, Muhammad Imran Nisart, Sandra Noltet, Ole F Norheimt, Luke Nyakarahukat, In-Hwan Oht, Takayoshi Ohkubot, Bolajoko O Olusanyat, Saad B Omert, John Nelson Opiot, Orish Ebere Orisakwet, Jeyaraj D Pandiant, Christina Papachristout, Jae-Hyun Parkt, AngelJ Paternina Caicedot, Scott B Pattent, Vinod K Pault, Boris Igor Pavlint, Neil Pearcet, David M Pereirat, Konrad Pesudovst, Max Petzoldt, Dan Poenarut, Guilherme V Polanczykt, Suzanne Polindert, Dan Popet, Farshad Pourmalekt, Dima Qatot, D Alex Quistbergt, Anwar Rafayt, Kazem Rahimi†, Vafa Rahimi-Movaghart, Sajjad ur Rahmant, Murugesan Rajut, Saleem M Ranat, Amany Refaatt, Luca Ronfanit, Nobhojit Roy†, Tania Georgina Sánchez Pimienta†, Mohammad Ali Sahraiant, Joshua A Salomont, Uchechukwu Sampsont, Itamar S Santost, Monika Sawhneyt, Felix Sayinzogat, lone J C Schneidert, Austin Schumachert, David C Schwebelt, Soraya Seedat $†$, Sadaf G Sepanlout, Edson E Servan-Morit, Marina Shakh-Nazarovat, Sara Sheikhbahaeit, Kenji Shibuyat, Hwashin Hyun Shint, Ivy Shivet, Inga Dora Sigfusdottirt, Donald H Silberbergt, Andrea P Silvat, Jasvinder A Singht, Vegard Skirbekkt, Karen Sliwat, Sergey S Soshnikovt, Luciano A Sposatot, Chandrashekhar T Sreeramareddy†, Konstantinos Stroumpoulist, Lela Sturuat, Bryan L Sykest, Karen M Tabbt, Roberto Tchio Talongwat, Feng Tant, Carolina Maria Teixeirat, Eric Yeboah Tenkorangt, Abdullah Sulieman Terkawit, Andrew L Thorne-Lymant, David L Tirschwellt, Jeffrey A Towbint, Bach X Trant, Miltiadis Tsilimbarist, Uche S Uchendut, Kingsley N Ukwajat, Eduardo A Undurragat, Selen Begüm Uzunt, Andrew JVallelyt, Coen H van Goolt, Tommi J Vasankarit, Monica S Vavilalat, N Venketasubramaniant, Salvador Villalpandot, Francesco S Violantet, Vasiliy Victorovich Vlassovt, Theo Vost, Stephen Wallert, Haidong Wangt, Linhong Wangt, XiaoRong Wangt, Yanping Wangt, Scott Weichenthalt, Elisabete Weiderpasst, Robert G Weintraubt, Ronny Westermant, James D Wilkinsont, Solomon Meseret Woldeyohannest, John Q Wongt, Mulvemebet Abera Wordofat, Gelin Xut, Yang C Yangt, Yuichiro Yanot, Gokalp Kadri Yenturt, Paul Yipt, Naohiro Yonemotot, Seok-Jun Yoont, Mustafa Z Younist, Chuanhua Yut, Kim Yun Jint,

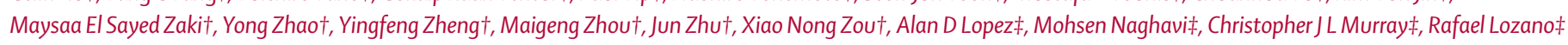

Lancet 2014; 384: 980-1004 Published Online May 2, 2014

http://dx.doi.org/10.1016/ S0140-6736(14)60696-6

See Comment page 933

This online publication has been corrected. The corrected

version first appeared at thelancet.com on Sept 12, 2014

\section{Summary}

Background The fifth Millennium Development Goal (MDG 5) established the goal of a 75\% reduction in the maternal mortality ratio (MMR; number of maternal deaths per 100000 livebirths) between 1990 and 2015. We aimed to measure levels and track trends in maternal mortality, the key causes contributing to maternal death, and timing of maternal death with respect to delivery.

Methods We used robust statistical methods including the Cause of Death Ensemble model (CODEm) to analyse a database of data for 7065 site-years and estimate the number of maternal deaths from all causes in 188 countries between 1990 and 2013. We estimated the number of pregnancy-related deaths caused by HIV on the basis of a systematic review of the relative risk of dying during pregnancy for HIV-positive women compared with HIV-negative 
women. We also estimated the fraction of these deaths aggravated by pregnancy on the basis of a systematic review. To estimate the numbers of maternal deaths due to nine different causes, we identified 61 sources from a systematic review and 943 site-years of vital registration data. We also did a systematic review of reports about the timing of maternal death, identifying 142 sources to use in our analysis. We developed estimates for each country for 1990-2013 using Bayesian meta-regression. We estimated 95\% uncertainty intervals (UIs) for all values.

Findings 292982 (95\% UI 261017-327 792) maternal deaths occurred in 2013, compared with 376034 (343 483-407574) in 1990. The global annual rate of change in the MMR was $-0.3 \%(-1 \cdot 1$ to 0.6$)$ from 1990 to 2003 , and $-2.7 \%$ $(-3.9$ to $-1 \cdot 5)$ from 2003 to 2013 , with evidence of continued acceleration. MMRs reduced consistently in south, east, and southeast Asia between 1990 and 2013, but maternal deaths increased in much of sub-Saharan Africa during the 1990s. 2070 (1290-2866) maternal deaths were related to HIV in 2013, 0 4\% (0 2-0 - 6) of the global total. MMR was highest in the oldest age groups in both 1990 and 2013. In 2013, most deaths occurred intrapartum or postpartum. Causes varied by region and between 1990 and 2013. We recorded substantial variation in the MMR by country in 2013, from $956 \cdot 8(685 \cdot 1-1262 \cdot 8)$ in South Sudan to $2 \cdot 4(1 \cdot 6-3 \cdot 6)$ in Iceland.

Interpretation Global rates of change suggest that only 16 countries will achieve the MDG 5 target by 2015. Accelerated reductions since the Millennium Declaration in 2000 coincide with increased development assistance for maternal, newborn, and child health. Setting of targets and associated interventions for after 2015 will need careful consideration of regions that are making slow progress, such as west and central Africa.

\section{Funding Bill \& Melinda Gates Foundation.}

\section{Introduction}

Since the 1980s, the global health community has focused on reducing maternal mortality through a sequence of initiatives, beginning with the Safe Motherhood movement in 1987, to the creation of the Partnership for Maternal, Newborn and Child Health in 2005. ${ }^{1,2}$ The priority accorded to reductions in maternal mortality is shown by its choice as one of the eight Millennium Development Goals (MDGs). Despite these efforts and visibility, there was broad concern that little or no progress was being made, which prompted intensified efforts by the UN Secretary General through the launch of Every Woman Every Child in 2010, and the subsequent creation of the Commission on Information and Accountability for Women's and Children's Health., In 2010, a comprehensive assessment of global trends in maternal mortality suggested that the maternal mortality ratio (MMR; number of maternal deaths per 100000 livebirths) had decreased by $1.3 \%$ per year since $1990 .{ }^{4}$ Subsequent revisions of the historical estimates have shown even larger worldwide rates of change, from $-1 \cdot 9 \%$ to $-3 \cdot 1 \%$ per year., ${ }^{5,6}$ This evidence collectively suggests that, although concerns about the rate of change of maternal mortality might have been too pessimistic, there is substantial uncertainty about how rapid the decrease has been and about the actual numbers of deaths in several large populations. If policy debates about acceleration of maternal mortality reductions are to be usefully informed, goals established, and targets set for reproductive health, up-to-date monitoring of the levels and trends in maternal mortality is essential.?

Compared with child mortality, maternal mortality has been more difficult to track over time at the national level. ${ }^{8}$ Several major challenges have to be addressed in any measurement effort: misclassification of maternal deaths to other causes in countries with complete vital registration and medical certification of causes of death; substantial sampling error in measurements that depend on survey recall because few maternal deaths are reported; large non-sampling error in survey and census measurements as demonstrated in settings with repeated overlapping measurements; variation in the demographic assessment of reproductive-age mortality from all causes, particularly in the 1990s; and the need for models to synthesise data from several studies or generate estimates when data are sparse..$^{-11}$ The substantial differences between global modelling efforts, which are at times substantial, emphasise the influence of each of the analytical steps used to estimate maternal mortality. ${ }^{12}$ Political attention to how countries are progressing towards MDG 5 targets is intensifying. ${ }^{1,13}$ Donors, global health partners, and national programme managers are understandably frustrated by the wide uncertainty intervals and the variability of estimates from different analysts. $^{8}$

Here, we use the systematic approach of the Global Burden of Diseases, Injuries, and Risk Factors Study 2013 (GBD 2013) to measure levels and track trends in maternal mortality, the key causes contributing to maternal death, and the timing of maternal deaths. In GBD 2013, with application of rigorous statistical methods to critically appraise and synthesise data from different sources to estimate levels and causes of death in each age and sex group, a consistent and holistic approach to the challenges of maternal mortality measurement is used that enables comparisons across time, country, and other important causes of death in women of reproductive age. Algorithms for cause of death reclassification are applied consistently across all causes and modelling strategies use methods with clearly
*Corresponding autho †Authors listed alphabetically †joint senior authors Institute for Health Metrics and Evaluation (N) Kassebaum MD, A Bertozzi-Villa BA, MS Coggeshall BA,

KA Shackelford BA, C Steiner MPH KR Heuton BS, D Gonzalez-Medina BA R Barber BS, C Huynh BA, D Dicker BS, TTemplin BA, TMWolockBA,

Prof L Dandona PhD M H Forouzanfar MD, S S Lim PhD Prof A H Mokdad PhD M Moradi-Lakeh MD, M Ng MD, A Schumacher BS, ProfT Vos PhD, HWang PhD, M Naghavi PhD, Prof CJL Murray PhD, Prof R Lozano MD), Department of Neurology (D L Tirschwell MD), Pediatric Anesthesiology and Pain Medicine, Seattle Children's Hospital, School of Medicine (N) Kassebaum), University of Washington, Seattle, WA, USA (RAlfonso-Cristancho PhD, $\mathrm{PN}$ Jensen $\mathrm{MPH}$, DA Quistberg PhD, MS Vavilala MD); Hacettepe University Institute of Population Studies, Ankara, Turkey (A Abbasoglu Ozgoren MA, A Cavlin PhD); Faculty of Medicine, Cairo University, Cairo, Egypt (Prof F Abd-Allah MD); School of Public Health, College of Health Sciences, Mekelle University, Mekelle, Tigray, Ethiopia (S F Abera MSc) University College London, London, UK

(Prof I Abubakar PhD); Ministry of Health, Gaborone, Botswana (TAchoki PhD); Public Health Promotion Alliance, Osogbp Nigeria (A Adelekan PhD); Centre for International Child Health (S M Colquhoun PhD), University of Melbourne, Melbourne, VIC, Australia (ZAdemi PhD, J B Blore PhD, R G Weintraub MB, Prof A D Lopez PhD); Association Ivoirienne Pour Le Bien Etre Familial, Abidjan, Côte d'Ivoire (A K Adou MD); University of Extremadura, Cáceres, Spain (Prof) C Adsuar PhD); Institution of Public Health Sciences, Stockholm, Sweden (EE Agardh PhD); Makerere University, Kampala, Uganda (D Akena PhD, L Nyakarahuka MPH); Ministry of Health, Muscat, Oman (D Alasfoor MSc, MJ Al Kahbouri PhD); Debre Markos University, Debre Markos, Amhara, Ethiopia 
(ZA Alemu MPH); National Guard Health Affairs, Riyadh, Saudi Arabia (S Alhabib PhD); University of Oxford, Oxford, UK (R Ali MSc, Prof SI Hay DPhil, K Rahimi DM); School of Public Health, University of Lorraine, Nancy, France (Prof FAlla PhD); Ministry of Health, Belmopan, Cayo, Belize (PJ Allen MPH); Saudi Ministry of Health, Riyadh, Saudi Arabia (M A AIMazroa MD, ProfZA Memish MD); Charité Universitätsmedizin Berlin, Berlin, Germany (U Alsharif DMD, S Nolte PhD, ( Papachristou PhD); Spanish Observatory on Drugs, Government Delegation for the National Plan on Drugs Pharmacoepidemiology and Pharmacovigilance, Spanish Medicines and Healthcare Products Agency (FCatalá-López PhD), Ministry of Health, Social Services and Equality, Madrid, Spain (E Alvarez PhD); Universidad de Cartagena, Cartagena de Indias, Colombia (Prof N Alvis-Guzmán PhD); Albany State University, Albany, GA, USA

(Prof A A Amankwaa PhD); Department of Epidemiology, (E Alvarez PhD), and Division of

quantified out-of-sample predictive validity. ${ }^{14}$ On the basis of recent trends in MMR, we also project an MMR scenario for 2030 to inform policy debates by identifying which countries are in greatest need of intensified focus.

\section{Methods \\ Maternal mortality 1990-2013}

Data

We used the GBD 2013 cause of death database, which extends from 1980 to 2013, to estimate maternal mortality. Although we report estimates for the MDG period 1990-2013, data for 1980-90 are included in the analysis to improve the robustness of the time trend estimation. Naghavi and colleagues ${ }^{15}$ provide substantial detail about

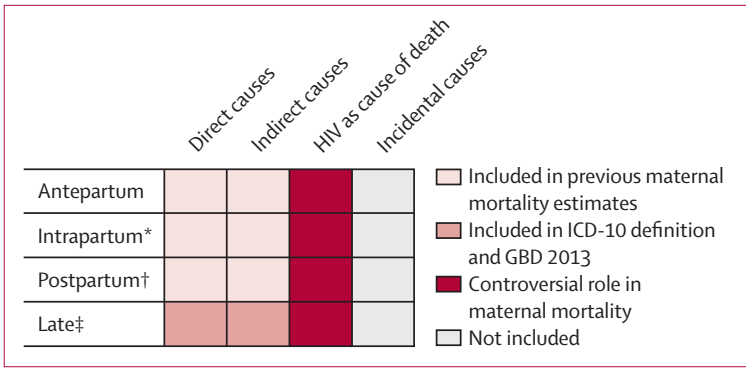

Figure 1: Definitions of maternal death

ICD-10=International Classification of Diseases, version 10. *During labour and up to $24 \mathrm{~h}$ after delivery. †Between $24 \mathrm{~h}$ and 6 weeks after delivery. $¥$ Between 6 weeks and 1 year after delivery.

\begin{tabular}{|c|c|c|c|c|c|}
\hline \multirow[b]{2}{*}{ Black } & \multirow{2}{*}{$\frac{\text { Year }}{2009}$} & \multicolumn{2}{|l|}{ Country } & \multirow{2}{*}{$\frac{\text { Relative risk (95\% UI) }}{6.25(3.65-10 \cdot 71)}$} & \multirow{2}{*}{$\begin{array}{c}\text { Weight (\%) } \\
8.34 \%\end{array}$} \\
\hline & & South Africa & $\dot{1}$ & & \\
\hline Chilongozi & 2008 & Malawi and Zambia & & $14 \cdot 40(0 \cdot 89-234 \cdot 16)$ & $2 \cdot 21 \%$ \\
\hline Coley & 2001 & Tanzania & \begin{tabular}{|c|c} 
\\
\end{tabular} & $3.70(0.41-32.95)$ & $3 \cdot 13 \%$ \\
\hline De Groot & 2003 & South Africa & $\Delta$ & $3.15(0.54-18.47)$ & $4.07 \%$ \\
\hline Khan & 2001 & South Africa & $\Delta$ & $2.68(1.78-4.04)$ & $8.73 \%$ \\
\hline Kourtis & 2006 & USA & $\Delta$ & $24.82(17.91-34.40)$ & $8.95 \%$ \\
\hline Kumar & 1995 & India & & $18.06(1.06-307.56)$ & $2 \cdot 16 \%$ \\
\hline Le Coeur & 2005 & Congo & 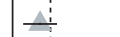 & $3.86(1.69-8.81)$ & $7 \cdot 29 \%$ \\
\hline Lepage & 1991 & Rwanda & & $0.33(0.01-8.17)$ & $1.79 \%$ \\
\hline Lionel & 2008 & India & & $7 \cdot 36(1.01-53 \cdot 58)$ & $3.55 \%$ \\
\hline Louis & 2007 & USA & & $13 \cdot 05(4 \cdot 02-42 \cdot 38)$ & $5.94 \%$ \\
\hline Maiques-Montesinos & 1999 & Spain & & $5.93(0.25-142.84)$ & $1.80 \%$ \\
\hline McDermott & 1996 & Malawi & & $2.13(0.48-9.46)$ & $4.86 \%$ \\
\hline Mmiro & 1993 & Uganda & & $6 \cdot 26(0.73-53 \cdot 40)$ & $3 \cdot 22 \%$ \\
\hline Nathoo & 2004 & Zimbabwe & & $2.03(0.18-22.27)$ & $2 \cdot 77 \%$ \\
\hline Nuwagaba-Biribonwoha & 2006 & Uganda & & $6.05(0.55-66.13)$ & $2 \cdot 77 \%$ \\
\hline Ryder & 1994 & DR Congo & & $17 \cdot 52(1 \cdot 02-302 \cdot 28)$ & $2 \cdot 14 \%$ \\
\hline Sewankambo & 2000 & Uganda & $\frac{1}{1}$ & $5.44(1.98-14.93)$ & $6 \cdot 57 \%$ \\
\hline Temmerman & 1994 & Kenya & is & $8.89(0.48-164.36)$ & $2 \cdot 07 \%$ \\
\hline Zaba & 2013 & $\begin{array}{l}\text { Uganda, Malawi, Tanzania, } \\
\text { Zimbabwe, South Africa }\end{array}$ & 4 & $8 \cdot 21(5 \cdot 73-11 \cdot 77)$ & $8.87 \%$ \\
\hline Zvandasara & 2006 & Zimbabwe & -1 & $11.85(7.94-17.69)$ & $8 \cdot 76 \%$ \\
\hline \multicolumn{2}{|c|}{ Overall $\left(I^{2}=79.5 \%, \mathrm{p}=0.000\right)$} & & $\begin{array}{l}\quad \hat{\rangle} \\
110 \\
\text { Relative risk }\end{array}$ & $6 \cdot 40(3.98-10 \cdot 29)$ & $100 \cdot 00 \%$ \\
\hline
\end{tabular}

Figure 2: Forest plot of the relative risk of death during pregnancy for women with HIV infection compared with women without HIV infection

Weights are from random effects analysis. Size of the triangles is proportional to the weighting of each study in the meta-analysis. UI=uncertainty interval. the inclusion criteria and data processing of studies across all causes. Briefly, building on previous analyses, we identified data from 180 of 188 GBD countries, including 4877 site-years of vital registration data, 1213 site-years of sibling histories from Demographic and Health Surveys (DHS) and Reproductive Health Surveys (RHS) providing information about the pregnancy-related fraction of reproductive-age deaths, 73 site-years of censuses, 626 site-years of maternal mortality surveillance, and 267 site-years of verbal autopsy analyses covering women of reproductive age. .5, $^{46}$ We identified the above data sources through a systematic review (appendix), from analyses by Lozano and colleagues $^{5}$ and GBD 2010 analyses, ${ }^{16}$ searches of Ministry of Health websites, and a search of the Global Health Data Exchange.

There has been much debate about which deaths of women of reproductive age should be included as maternal deaths. To be classified as maternal, pregnancy needs to be a causal factor in death. It can either have a direct effect (complications of the pregnancy or childbirth, or postpartum complications) or indirect effect (exacerbation of a pre-existing condition). Therefore, accidental or incidental deaths in which pregnancy had no causal role are not classified as maternal deaths. Definitions for national use based on the International Classification of Diseases (ICD) have differed from other recommendations for international comparisons of the MMR. All definitions include direct and indirect causes during pregnancy and within 6 weeks of the termination of pregnancy (figure 1). ICD-10 definitions also include late maternal deaths between 6 weeks and 1 year after termination. ${ }^{6,17}$ For some causes, such as suicide, there is national variation in whether they are coded as incidental or indirect. ${ }^{18,19}$ MDG guidance for cross-country comparisons of MMR recommends that all HIV-related deaths during pregnancy or within 6 weeks should be included in the MMR, ${ }^{20}$ but the UN group estimating maternal mortality uses only $50 \%$ of these deaths in their estimation. ${ }^{6,20}$ Conceptually, only the fraction of deaths aggravated by pregnancy should be included, because that is the definition of an indirect cause of maternal mortality.

We included direct and indirect deaths during pregnancy and within 6 weeks of delivery, plus late maternal deaths up to 1 year after delivery and the fraction of HIV-related deaths aggravated by pregnancy. Late maternal deaths were not coded in ICD-9 so data are only available for ICD-10 (ie, from 1994). Additionally, because maternal deaths in the age group 10-14 years have been consistently reported in our data sources, we have estimated the number of maternal deaths in this age group but have not included them in the computation of the MMR because no standard estimates of birth rates are available for this group.

In vital registration and verbal autopsy data, maternal deaths are often misclassified as deaths attributable to 
other underlying causes. We reassigned deaths assigned to causes that are unlikely to be underlying causes of death with standardised algorithms. ${ }^{14}$ The causes of death that are partly reassigned to maternal causes are shown in the appendix..$^{15}$ We reanalysed DHS and RHS microdata for sibling deaths that were related to pregnancy by year using Gakidou-King weights to deal with potential survivor bias. ${ }^{21}$ We used a Bayesian noise reduction algorithm to preprocess data to avoid the issue of large stochastic fluctuations and zero counts leading to distorted time trends (appendix). When different DHS surveys provided data for reproductive-age deaths and the number that were related to pregnancy for the same year, we pooled results for that year to reduce stochastic measurement error. Additionally, for some vital registration data, no maternal deaths are reported in specific age group or for a specific period. Noise reduction algorithms again help to reduce upward bias because all zero counts would otherwise be dropped from natural logarithm death rate and logit cause fraction models. Data were unavailable for only eight countries, for which we relied entirely on model predictions for maternal mortality estimates.

\section{HIV-related mortality}

Because of the rapid increase in reproductive-age mortality due to the HIV epidemic in eastern and southern Africa, disentangling the fraction of HIV deaths during pregnancy that are incidental (ie, not related to pregnancy) from those aggravated by pregnancy (ie, maternal deaths) is important. Assessment of HIVrelated mortality during pregnancy has two steps: estimation of the fraction of deaths during pregnancy or within 6 weeks of delivery that are related to HIV, and estimation of the fraction of these HIV-related deaths that are aggravated by pregnancy. For the first step, we updated Calvert and Ronsmans' systematic review ${ }^{22}$ (appendix). We identified one new study, giving a total of 21 for which we could examine mortality risk during pregnancy for HIV-positive versus HIV-negative women..$^{23-43}$ We excluded data from non-representative populations, from sources that did not include postpartum deaths, and any deaths more than 1 year after delivery. Most studies did not specify antiretroviral therapy (ART) status. We undertook a DerSimonianLaird meta-analysis of the relative risk (RR) of death. Studies were heterogeneous and the pooled RR was $6 \cdot 40$ (figure 2). We identified no clear geographical pattern to explain why some studies are significantly above or below the pooled estimate, nor any clear relation with other study attributes, meaning that we had an insufficient basis for further weighting of input studies.

We used the RR and estimated HIV prevalence in pregnant women (based on the UNAIDS Spectrum model) to estimate the population attributable fraction of pregnancy-related deaths that are related to HIV. To estimate the fraction of HIV-related deaths aggravated by pregnancy, we did another systematic review (appendix).
We could identify only two studies to inform this fraction, with a pooled RR of 1.13 (95\% UI $0.73-1 \cdot 77),{ }^{4,45}$ corresponding to a frequency of all HIV-related deaths during pregnancy that should be counted as maternal deaths of $11.5 \%(0-43 \cdot 5)$. Several additional studies did not show increased risk of HIV-related mortality during pregnancy, but were excluded because stratification of the study population on the basis of stage of HIV or ART status was not completed.

\section{Modelling}

Following Lozano and colleagues' methods, ${ }^{5}$ we used the Cause of Death Ensemble model (CODEm) to model maternal mortality by age (appendix). With CODEm, many models are developed and their performance is assessed objectively. ${ }^{46}$ We selected nine covariates for CODEm to test on the basis of previously reported associations that also have a plausible causal association with maternal mortality: age-specific fertility rate, total fertility rate, age-standardised HIV death rate for female individuals aged 15-49 years, neonatal death rate, lagdistributed gross domestic product (GDP) per person (GDP per person computed with a triangle lag that weights more recent years more heavily), proportion of deliveries occurring in facilities, proportion of deliveries overseen by skilled birth attendants, coverage of four visits of antenatal care, and malnutrition in children younger than 5 years ( $<2$ SD below mean weight for age; used as a proxy for adult nutritional status; appendix).

We divided covariates into three groups to enable computation. Level 1 covariates had the strongest likely relation with maternal mortality; covariates in levels 2 and 3 had weaker likely relations. CODEm tests all combinations of level 1 covariates and nearly every combination of level 2 and level 3 covariates using four families of models: mixed effects linear regression of the logit-transformed cause-specific mortality fraction, spatial-temporal Gaussian Process Regression (ST-GPR) of the logit-transformed cause-specific mortality rate, mixed effects linear regression of the natural log of the maternal death rate, and ST-GPR of the natural log of the maternal death rate. ${ }^{46} 30 \%$ of the data were not included in the models. Models were retained when the beta for each covariate was significant and in the direction allowed by previous evidence. The performance of each retained model was then assessed with half the held-out data in terms of the root-mean squared error of the prediction of the model compared with the data held out, and the root-mean squared error of the trend in the model compared with the trend in the data. Ensemble models were developed on the basis of the rankings of individual models and the performance of different ensembles assessed in the second half of the data held out of the regression (appendix). The best performing ensemble was selected and refitted to all data.

One of the strengths of the GBD is that all causes are simultaneously estimated. Estimates of every
University of Groningen, Groningen, Netherlands (ATAmare MPH); College of Medicine and Health Sciences, Bahir Dar University, Bahir Dar, Ethiopia (AT Amare); Kurdistan Environmental Health Research Centre, Kurdistan University of Medical Sciences, Sanandaj,

Kurdistan, Iran (H Amini MSPH); Ministry of Public Health, Beirut, Lebanon (W Ammar PhD, H L Harb MPH); College of Public Health, University of the

Philippines Manila, Manila Philippines (CAT Antonio MD, EJ A Faraon MD); UN Population Fund, Kabul, Afghanistan (PAnwari MSc); Uppsala University, Uppsala, Sweden (J Ärnlöv PhD, Prof A Larsson PhD); Institute of Microbiology and Immunology, School of Medicine, University of Belgrade, Belgrade, Serbia (Prof V S Arsic Arsenijevic PhD); Median, Windsor, ON, Canad (A Artaman PhD); Ministry of Health, Amman, Jordan (M M Asad PhD); Field Epidemiology and Laboratory Training Program, Islamabad, Pakistan (RJAsghar MD); Mashhad University of Medical Sciences, Mashhad, Iran (R Assadi MD); Ministry of Health, Wellness, Human Services and Gender Relations, Sans Souci, Castries, Saint Lucia (LS Atkins MPH); Public Health Agency of Canada, Toronto, ON, Canada (A Badawi PhD); Sri Ramachandra University, Chennai, India (K Balakrishnan PhD); School of Health Sciences, University of Canterbury, Christchurch, New Zealand (A Basu PhD); School of Medicine (L Gaffikin DrPH); Stanford University, Stanford, CA, USA (S Basu PhD); Oxford University, Ho Chi Minh City, Vietnam (J Beardsley MBChB); College of Public Health and Tropical Medicine, Jazan, Saudi Arabia (N Bedi MD); Madawalabu University, Bale Goba, Oromia, Ethiopia (T Bekele MPH); Yale University, New Haven, CT, USA (Prof M L Bell PhD); King's College London, London, UK (E Bernabe PhD); Addis Ababa University, Debre Zeit, Ethiopia (TJ Beyene MSC, K Deribe MPH); Aga Khan University Medical Centre (Prof Z Bhutta PhD); Aga Khan University (M I Nisar MSC) Karachi, Pakistan; University of Missouri-Kansas City, Kansas City, MO, USA (A Bin Abdulhak MD); General 
Directorate of Health Research (B Bora Basara PhD, U Dilmen MD, $\mathrm{G} \mathrm{K}$ Yentur PhD); Ministry of Health, Ankara, Turkey (S B Uzun MD); World Bank, Washington, DC, USA (D Bose PhD); University of Arizona, Tucson, AZ, USA (Prof N Breitborde PhD); Universidad Autonoma Metropolitana, Mexico City, Mexico (R Cárdenas SCD); Colombian National Health Observatory, Instituto Nacional de Salud, Bogota, Colombia (CA Castañeda-Orjuela MSc); Universidad Diego Portales, Santiago, Chile (R E Castro PhD); College of Public Health (H-H Lin ScD), National Taiwan University, Taipei, Taiwan (ProfJ-C Chang PhD); National Institutes of Health, Department of Health and Human Services,

Figure 3: Global maternal deaths (A) and annualised rate of change in maternal mortality ratio (B), 1990-2013 Shaded areas show $95 \%$ uncertainty intervals.

cause-specific death rate are necessary to sum to all-cause mortality using the CoDCorrect algorithm. ${ }^{16}$ To ensure they do sum to all-cause mortality, at the level of each draw from the posterior distribution of each cause of death for a specific country, year, and age group, the sum of all causes was rescaled to equal a draw taken from the uncertainty distribution of all-cause mortality for that country, year, and age group.

\section{Causes of maternal death}

We disaggregated maternal deaths into nine causes: maternal haemorrhage, maternal sepsis and other pregnancy-related infections, hypertensive disorders of pregnancy, obstructed labour, abortion, other direct maternal disorders, indirect maternal disorders, HIV, and late maternal deaths. To estimate the different causes of maternal death, we completed a systematic review (appendix) to identify data to inform which proportion of total maternal deaths is due to each cause. Additionally, we incorporated all vital registration and

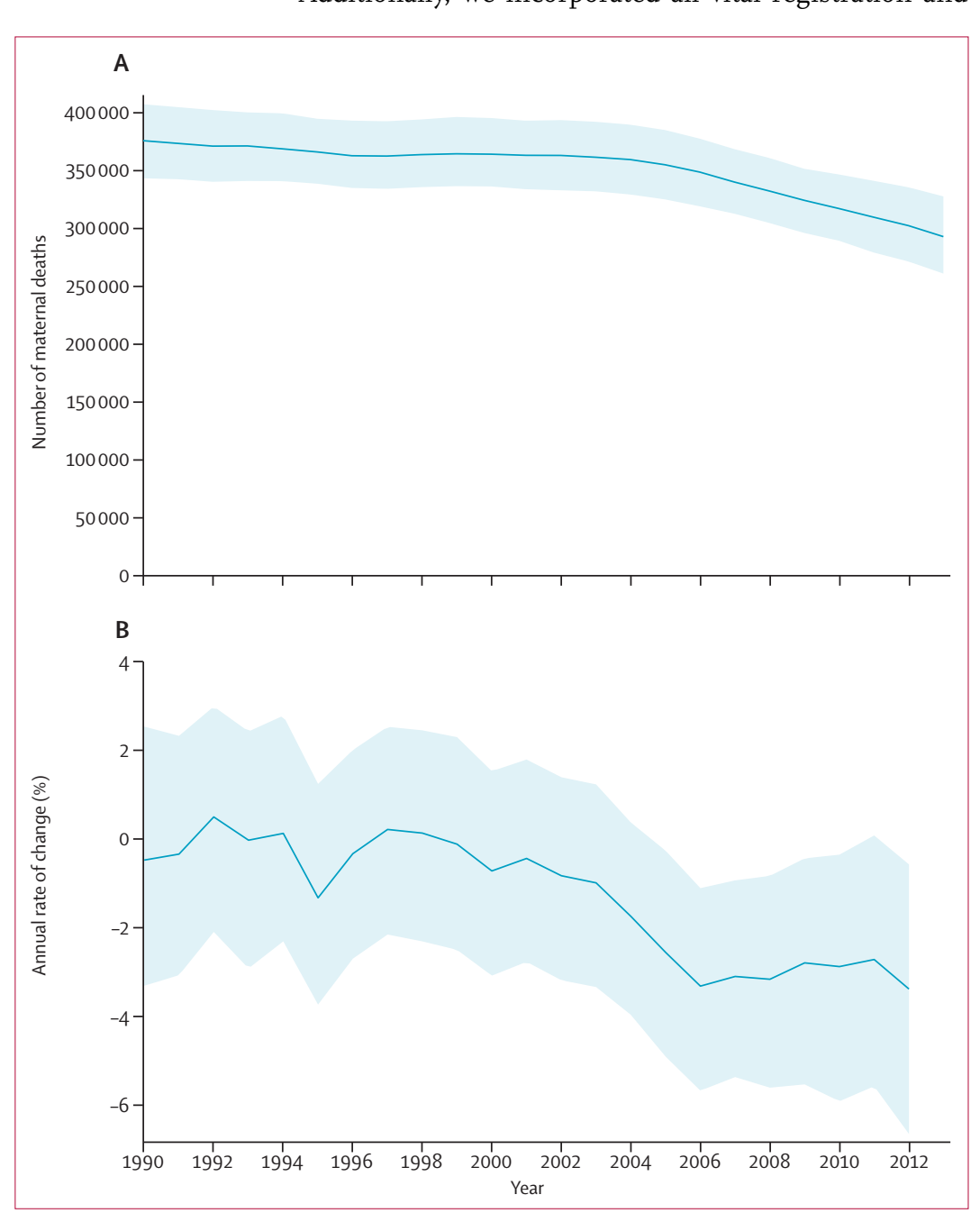

sample registration data that provided ICD-coded detail for maternal causes (appendix). We identified 61 studies and, after processing, included 943 site-years of vital registration, sample registration, and maternal mortality surveillance data.

We modelled the proportion of maternal deaths for all causes except HIV using DisMod-MR (version 2.0), which is a Bayesian meta-regression tool developed for the GBD (appendix). This version of DisMod-MR allows for two types of fixed effects (study attributes and country covariates) and includes nested random effects for superregion, region, and country. A key advantage of DisModMR is that it can handle data reported for any age interval. Predictions from DisMod-MR for each group divided by country, year, and age are based on the country covariates, reference values of the study level covariates, and hierarchical random effects. Point estimates with uncertainty were produced for six discrete points: 1990 , 1995, 2000, 2005, 2010, and 2013. Each cause was modelled independently. Predicted cause fractions for each group were rescaled to equal $100 \%$ of the deaths not related to HIV. The rescaled cause fractions were then multiplied by the number of maternal deaths in each group (divided by country, year, and age) to obtain the number of deaths for each maternal cause, a sum to which the HIV deaths were added. The final result includes cause fraction and number of maternal deaths due to each cause, country, age group, and year.

\section{Timing of maternal deaths}

An important issue for planning of interventions is an understanding of the timing of maternal deaths with respect to labour and delivery. ${ }^{47}$ We completed a systematic review to identify studies of the timing of maternal deaths (appendix). We identified 142 studies and used vital registration, sample registration, and surveillance data for late maternal death. Many studies combined the first $24 \mathrm{~h}$ postpartum (immediate or early postpartum) with the intrapartum period, because events of the immediate postpartum period are clinically related to events occurring during labour and delivery. Therefore, we also combined intrapartum and immediate postpartum periods. We followed this format to construct a dataset that included four different time windows: deaths occurring antepartum (before onset of labour), deaths occurring intrapartum or during the immediate postpartum period (up to $24 \mathrm{~h}$ after delivery), deaths occurring during the subacute and delayed postpartum periods ( $24 \mathrm{~h}$ to 42 days after delivery), ${ }^{47}$ and late maternal deaths (43 days to 1 year after delivery). We modelled the proportion of maternal deaths in each of the four periods with DisMod-MR (version 2.0). The predicted proportions were scaled to $100 \%$ for each group.

\section{0 scenario and rate-of-change calculations}

We developed a straightforward forecast scenario for the MMR for every country in 2030 by using the estimated 


\begin{tabular}{|c|c|c|c|c|c|c|c|c|c|}
\hline & \multicolumn{3}{|c|}{ Maternal mortality ratio (per 100000 livebirths) } & \multicolumn{3}{|c|}{ Number of maternal deaths } & \multicolumn{3}{|c|}{$\begin{array}{l}\text { Annualised rate of change in maternal } \\
\text { mortality ratio }(\%)\end{array}$} \\
\hline & 1990 & 2003 & 2013 & 1990 & 2003 & 2013 & $1990-2003$ & 2003-13 & 1990-2013 \\
\hline Worldwide & $\begin{array}{l}283.2 \\
\text { (258.6 to } 306 \cdot 9)\end{array}$ & $\begin{array}{l}273 \cdot 4 \\
\text { (251.1 to } 296 \cdot 6)\end{array}$ & $\begin{array}{l}209 \cdot 1 \\
(186 \cdot 3 \text { to } 233 \cdot 9)\end{array}$ & $\begin{array}{l}376034 \\
(343483 \text { to } 407574)\end{array}$ & $\begin{array}{l}361706 \\
\text { (332230 to 392393) }\end{array}$ & $\begin{array}{l}292982 \\
\text { (261017 to 327792) }\end{array}$ & $\begin{array}{l}-0.3 \% \\
\text { (-1.1 to } 0.6)\end{array}$ & $\begin{array}{l}-2 \cdot 7 \% \\
(-3.9 \text { to }-1.5)\end{array}$ & $\begin{array}{l}-1 \cdot 3 \% \\
(-1 \cdot 9 \text { to }-0.8)\end{array}$ \\
\hline $\begin{array}{l}\text { Developed } \\
\text { countries }\end{array}$ & $\begin{array}{l}24 \cdot 5 \\
(23 \cdot 0 \text { to } 26 \cdot 1)\end{array}$ & $\begin{array}{l}16 \cdot 0 \\
(14 \cdot 9 \text { to } 17 \cdot 0)\end{array}$ & $\begin{array}{l}12 \cdot 1 \\
(10 \cdot 4 \text { to } 13 \cdot 7)\end{array}$ & $\begin{array}{l}3827 \\
\text { (3596 to 4076) }\end{array}$ & $\begin{array}{c}2341 \\
\text { (2178 to } 2490)\end{array}$ & $\begin{array}{c}1811 \\
(1560 \text { to } 2053)\end{array}$ & $\begin{array}{l}-3 \cdot 3 \% \\
(-3 \cdot 8 \text { to }-2 \cdot 8)\end{array}$ & $\begin{array}{l}-2 \cdot 9 \% \\
(-4 \cdot 2 \text { to }-1 \cdot 5)\end{array}$ & $\begin{array}{l}-3 \cdot 1 \% \\
(-3 \cdot 7 \text { to }-2 \cdot 5)\end{array}$ \\
\hline $\begin{array}{l}\text { Developing } \\
\text { countries }\end{array}$ & $\begin{array}{l}317.6 \\
\text { (289.9 to } 344.5)\end{array}$ & $\begin{array}{l}305 \cdot 4 \\
(280 \cdot 3 \text { to } 331 \cdot 5)\end{array}$ & $\begin{array}{l}232 \cdot 8 \\
(207 \cdot 3 \text { to } 260 \cdot 6)\end{array}$ & $\begin{array}{l}372207 \\
\text { (339780 to 403753) }\end{array}$ & $\begin{array}{l}359365 \\
\text { (329892 to 390100) }\end{array}$ & $\begin{array}{l}291171 \\
\text { (259299 to 325923) }\end{array}$ & $\begin{array}{l}-0.3 \% \\
(-1 \cdot 2 \text { to } 0 \cdot 6)\end{array}$ & $\begin{array}{l}-2 \cdot 7 \% \\
(-4 \cdot 0 \text { to }-1 \cdot 5)\end{array}$ & $\begin{array}{l}-1 \cdot 4 \% \\
(-1.9 \text { to }-0.8)\end{array}$ \\
\hline $\begin{array}{l}\text { High-income } \\
\text { Asia Pacific }\end{array}$ & $\begin{array}{l}16 \cdot 4 \\
(14 \cdot 4 \text { to } 18 \cdot 4)\end{array}$ & $\begin{array}{l}10 \cdot 3 \\
\text { (8.9 to } 12 \cdot 1)\end{array}$ & $\begin{array}{c}7.9 \\
(6 \cdot 3 \text { to } 9 \cdot 9)\end{array}$ & $\begin{array}{c}325 \\
\text { (285 to } 363)\end{array}$ & $\begin{array}{c}173 \\
(150 \text { to } 204)\end{array}$ & $\begin{array}{c}128 \\
\text { (103 to } 162)\end{array}$ & $\begin{array}{l}-3 \cdot 6 \% \\
(-4 \cdot 9 \text { to }-2 \cdot 1)\end{array}$ & $\begin{array}{l}-2 \cdot 7 \% \\
(-4.6 \text { to }-0.6)\end{array}$ & $\begin{array}{l}-3 \cdot 2 \% \\
(-4 \cdot 2 \text { to }-2 \cdot 0)\end{array}$ \\
\hline Brunei & $\begin{array}{l}27.2 \\
(18.9 \text { to } 39.0)\end{array}$ & $\begin{array}{l}18 \cdot 6 \\
(13 \cdot 8 \text { to } 24 \cdot 6)\end{array}$ & $\begin{array}{l}14 \cdot 6 \\
(9 \cdot 8 \text { to } 21 \cdot 1)\end{array}$ & $(1 \text { to } 3)^{2}$ & $(1 \text { to } 2)^{1}$ & $(1 \text { to } 1)^{1}$ & $\begin{array}{l}-2 \cdot 9 \% \\
(-6 \cdot 3 \text { to } 0.4)\end{array}$ & $\begin{array}{l}-2.5 \% \\
\text { (-6.7 to 1.9) }\end{array}$ & $\begin{array}{l}-2 \cdot 7 \% \\
(-5 \cdot 0 \text { to }-0.4)\end{array}$ \\
\hline Japan & $\begin{array}{l}14 \cdot 2 \\
(12 \cdot 2 \text { to } 16 \cdot 2)\end{array}$ & $\begin{array}{c}8 \cdot 2 \\
\text { (6.8 to 9.8) }\end{array}$ & $\begin{array}{c}6.1 \\
(4.7 \text { to } 7 \cdot 9)\end{array}$ & $\begin{array}{c}171 \\
\text { (148 to } 195)\end{array}$ & $\begin{array}{c}94 \\
\text { (78 to } 113 \text { ) }\end{array}$ & $\begin{array}{c}66 \\
\text { (51 to } 86 \text { ) }\end{array}$ & $\begin{array}{l}-4 \cdot 3 \% \\
(-5 \cdot 7 \text { to }-2 \cdot 6)\end{array}$ & $\begin{array}{l}-2 \cdot 9 \% \\
(-5 \cdot 7 \text { to }-0.2)\end{array}$ & $\begin{array}{l}-3 \cdot 7 \% \\
(-4 \cdot 9 \text { to }-2 \cdot 3)\end{array}$ \\
\hline Singapore & $\begin{array}{l}10 \cdot 4 \\
\text { (8.5 to } 12.8)\end{array}$ & $\begin{array}{c}8.8 \\
\text { (7.2 to } 10 \cdot 8)\end{array}$ & $\begin{array}{c}4.5 \\
\text { (3.4 to } 5.8)\end{array}$ & (5 to 7$)^{6}$ & $\begin{array}{l}{ }^{4} \\
\text { (3 to } 5)^{4}\end{array}$ & $(2 \text { to } 3)^{2}$ & $\begin{array}{l}-1 \cdot 2 \% \\
\text { (-3.3 to } 0.7)\end{array}$ & $\begin{array}{l}-6.8 \% \\
(-9.4 \text { to }-3.9)\end{array}$ & $\begin{array}{l}-3 \cdot 6 \% \\
(-5 \cdot 3 \text { to }-2 \cdot 2)\end{array}$ \\
\hline South Korea & $\begin{array}{l}20.7 \\
\text { (17.5 to } 23.9)\end{array}$ & $\begin{array}{l}15 \cdot 4 \\
(12 \cdot 8 \text { to } 19 \cdot 0)\end{array}$ & $\begin{array}{c}12 \cdot 0 \\
\text { (8.7 to } 16 \cdot 7)\end{array}$ & $\begin{array}{c}145 \\
\text { (123 to } 168)\end{array}$ & $\begin{array}{c}74 \\
\text { (61 to } 91 \text { ) }\end{array}$ & $\begin{array}{c}58 \\
\text { (42 to } 81 \text { ) }\end{array}$ & $\begin{array}{l}-2 \cdot 3 \% \\
(-4 \cdot 3 \text { to }-0.1)\end{array}$ & $\begin{array}{l}-2.6 \% \\
(-5.7 \text { to } 0.4)\end{array}$ & $\begin{array}{l}-2.4 \% \\
(-3.9 \text { to }-0.7)\end{array}$ \\
\hline Central Asia & $\begin{array}{l}61.7 \\
(58 \cdot 0 \text { to } 65 \cdot 6)\end{array}$ & $\begin{array}{l}45 \cdot 1 \\
(41 \cdot 6 \text { to } 49 \cdot 0)\end{array}$ & $\begin{array}{l}31 \cdot 5 \\
\text { (27.0 to } 37.0)\end{array}$ & $\begin{array}{c}1188 \\
\text { (1119 to } 1265)\end{array}$ & $\begin{array}{c}724 \\
\text { (668 to } 786)\end{array}$ & $\begin{array}{c}569 \\
\text { (487 to } 668)\end{array}$ & $\begin{array}{l}-2 \cdot 4 \% \\
(-3 \cdot 2 \text { to }-1 \cdot 7)\end{array}$ & $\begin{array}{l}-3 \cdot 6 \% \\
(-5 \cdot 4 \text { to }-1 \cdot 9)\end{array}$ & $\begin{array}{l}-2 \cdot 9 \% \\
(-3 \cdot 6 \text { to }-2 \cdot 2)\end{array}$ \\
\hline Armenia & $\begin{array}{l}43 \cdot 3 \\
(36 \cdot 0 \text { to } 51 \cdot 3)\end{array}$ & $\begin{array}{l}35 \cdot 2 \\
\text { (29.1 to } 42 \cdot 5)\end{array}$ & $\begin{array}{l}18 \cdot 3 \\
\text { (13.9 to 23.4) }\end{array}$ & $\begin{array}{c}32 \\
\text { (26 to } 38)\end{array}$ & $\begin{array}{c}15 \\
\text { (13 to } 19)\end{array}$ & $\begin{array}{r}8 \\
(6 \text { to } 10)\end{array}$ & $\begin{array}{l}-1 \cdot 6 \% \\
(-3 \cdot 5 \text { to } 0.4)\end{array}$ & $\begin{array}{l}-6 \cdot 6 \% \\
(-9.7 \text { to }-3.6)\end{array}$ & $\begin{array}{l}-3 \cdot 8 \% \\
(-5 \cdot 1 \text { to }-2 \cdot 4)\end{array}$ \\
\hline Azerbaijan & $\begin{array}{l}42 \cdot 4 \\
(36 \cdot 6 \text { to } 49 \cdot 0)\end{array}$ & $\begin{array}{l}37 \cdot 3 \\
\text { (31.4 to } 44 \cdot 2)\end{array}$ & $\begin{array}{l}23 \cdot 9 \\
\text { (17.1 to 33.9) }\end{array}$ & $\begin{array}{c}84 \\
\text { (72 to } 97)\end{array}$ & $\begin{array}{c}57 \\
(48 \text { to } 67)\end{array}$ & $\begin{array}{c}40 \\
\text { (29 to } 57)\end{array}$ & $\begin{array}{l}-1.0 \% \\
(-2 \cdot 8 \text { to } 0.8)\end{array}$ & $\begin{array}{l}-4 \cdot 6 \% \\
(-8 \cdot 2 \text { to }-0.4)\end{array}$ & $\begin{array}{l}-2 \cdot 5 \% \\
(-4.0 \text { to }-1.0)\end{array}$ \\
\hline Georgia & $\begin{array}{l}42 \cdot 0 \\
\text { (35.4 to } 49 \cdot 8)\end{array}$ & $\begin{array}{l}31 \cdot 7 \\
\text { (26.3 to 38.0) }\end{array}$ & $\begin{array}{l}31 \cdot 1 \\
\text { (24.7 to 38.8) }\end{array}$ & $\begin{array}{c}37 \\
(32 \text { to } 44)\end{array}$ & $\begin{array}{c}19 \\
(16 \text { to } 23)\end{array}$ & $\begin{array}{c}18 \\
\text { (14 to } 23)\end{array}$ & $\begin{array}{l}-2 \cdot 2 \% \\
(-4 \cdot 1 \text { to }-0 \cdot 2)\end{array}$ & $\begin{array}{l}-0.2 \% \\
(-3.0 \text { to } 2 \cdot 6)\end{array}$ & $\begin{array}{l}-1 \cdot 3 \% \\
(-2 \cdot 4 \text { to }-0.1)\end{array}$ \\
\hline Kazakhstan & $\begin{array}{l}70.9 \\
(62 \cdot 1 \text { to } 80.0)\end{array}$ & $\begin{array}{l}36 \cdot 0 \\
\text { (31.0 to } 41 \cdot 7)\end{array}$ & $\begin{array}{l}27.0 \\
\text { (19.5 to } 35 \cdot 4)\end{array}$ & $\begin{array}{c}247 \\
\text { (216 to } 278)\end{array}$ & $\begin{array}{c}105 \\
\text { (91 to } 122)\end{array}$ & $\begin{array}{c}90 \\
\text { (65 to } 118)\end{array}$ & $\begin{array}{l}-5 \cdot 2 \% \\
(-6 \cdot 6 \text { to }-3 \cdot 6)\end{array}$ & $\begin{array}{l}-2.9 \% \\
(-6.5 \text { to } 0.4)\end{array}$ & $\begin{array}{l}-4 \cdot 2 \% \\
(-5 \cdot 6 \text { to }-2 \cdot 9)\end{array}$ \\
\hline Kyrgyzstan & $\begin{array}{l}62.5 \\
\text { (54.3 to } 71.4)\end{array}$ & $\begin{array}{l}58 \cdot 3 \\
(50 \cdot 6 \text { to } 66 \cdot 8)\end{array}$ & $\begin{array}{l}46 \cdot 8 \\
\text { (35.9 to } 59 \cdot 2 \text { ) }\end{array}$ & $\begin{array}{c}84 \\
\text { (73 to } 95)\end{array}$ & $\begin{array}{c}66 \\
\text { (58 to } 76 \text { ) }\end{array}$ & $\begin{array}{c}69 \\
\text { (53 to } 88 \text { ) }\end{array}$ & $\begin{array}{l}-0.5 \% \\
(-2 \cdot 1 \text { to } 1.0)\end{array}$ & $\begin{array}{l}-2 \cdot 3 \% \\
(-5 \cdot 2 \text { to } 0.5)\end{array}$ & $\begin{array}{l}-1 \cdot 3 \% \\
(-2 \cdot 5 \text { to }-0.1)\end{array}$ \\
\hline Mongolia & $\begin{array}{l}180 \cdot 2 \\
(137 \cdot 4 \text { to } 233 \cdot 0)\end{array}$ & $\begin{array}{l}96 \cdot 3 \\
(74 \cdot 6 \text { to } 122 \cdot 7)\end{array}$ & $\begin{array}{l}51 \cdot 3 \\
\text { (34.2 to } 72 \cdot 3)\end{array}$ & $\begin{array}{c}108 \\
\text { (82 to } 139)\end{array}$ & $\begin{array}{c}50 \\
\text { (39 to } 63)\end{array}$ & $\begin{array}{c}33 \\
(22 \text { to } 46)\end{array}$ & $\begin{array}{l}-4 \cdot 8 \% \\
(-7 \cdot 5 \text { to }-2 \cdot 1)\end{array}$ & $\begin{array}{l}-6 \cdot 4 \% \\
(-10 \cdot 7 \text { to }-2 \cdot 1)\end{array}$ & $\begin{array}{l}-5 \cdot 5 \% \\
(-7 \cdot 5 \text { to }-3 \cdot 6)\end{array}$ \\
\hline Tajikistan & $\begin{array}{l}74 \cdot 6 \\
(65 \cdot 3 \text { to } 86 \cdot 4)\end{array}$ & $\begin{array}{l}49 \cdot 4 \\
(42 \cdot 2 \text { to } 57 \cdot 8)\end{array}$ & $\begin{array}{l}30 \cdot 4 \\
\text { (22.2 to } 39 \cdot 3)\end{array}$ & $\begin{array}{c}154 \\
\text { (135 to } 178)\end{array}$ & $\begin{array}{c}98 \\
\text { (84 to } 115)\end{array}$ & $\begin{array}{c}82 \\
\text { (60 to } 106)\end{array}$ & $\begin{array}{l}-3 \cdot 2 \% \\
(-4 \cdot 9 \text { to }-1 \cdot 6)\end{array}$ & $\begin{array}{l}-4 \cdot 9 \% \\
(-8 \cdot 2 \text { to }-1 \cdot 9)\end{array}$ & $\begin{array}{l}-3 \cdot 9 \% \\
(-5 \cdot 4 \text { to }-2 \cdot 7)\end{array}$ \\
\hline Turkmenistan & $\begin{array}{l}72 \cdot 9 \\
(63 \cdot 2 \text { to } 83 \cdot 1)\end{array}$ & $\begin{array}{l}61 \cdot 2 \\
(41 \cdot 1 \text { to } 83 \cdot 7)\end{array}$ & $\begin{array}{l}38 \cdot 2 \\
\text { (22.9 to } 55 \cdot 5)\end{array}$ & $\begin{array}{c}91 \\
\text { (79 to } 103 \text { ) }\end{array}$ & $\begin{array}{c}64 \\
\text { (43 to } 88)\end{array}$ & $\begin{array}{c}42 \\
\text { (25 to } 61)\end{array}$ & $\begin{array}{l}-1 \cdot 4 \% \\
(-4 \cdot 6 \text { to } 1 \cdot 3)\end{array}$ & $\begin{array}{l}-4 \cdot 8 \% \\
(-9.7 \text { to }-0.1)\end{array}$ & $\begin{array}{l}-2 \cdot 9 \% \\
(-5 \cdot 0 \text { to }-1 \cdot 1)\end{array}$ \\
\hline Uzbekistan & $\begin{array}{l}50.7 \\
\text { (45.4 to } 56 \cdot 8)\end{array}$ & $\begin{array}{l}42 \cdot 4 \\
\text { (36.6 to } 48 \cdot 9)\end{array}$ & $\begin{array}{l}30 \cdot 5 \\
\text { (21.0 to } 42 \cdot 6)\end{array}$ & $\begin{array}{c}353 \\
\text { (315 to 395) }\end{array}$ & $\begin{array}{c}249 \\
\text { (215 to 287) }\end{array}$ & $\begin{array}{c}187 \\
\text { (129 to 262) }\end{array}$ & $\begin{array}{l}-1 \cdot 4 \% \\
(-2 \cdot 8 \text { to }-0.1)\end{array}$ & $\begin{array}{l}-3 \cdot 4 \% \\
(-6.8 \text { to } 0.4)\end{array}$ & $\begin{array}{l}-2 \cdot 3 \% \\
(-3 \cdot 9 \text { to }-0.7)\end{array}$ \\
\hline East Asia & $\begin{array}{l}139 \cdot 5 \\
(113 \cdot 1 \text { to } 167 \cdot 1)\end{array}$ & $\begin{array}{l}63.9 \\
(58 \cdot 1 \text { to } 69 \cdot 7)\end{array}$ & $\begin{array}{l}18 \cdot 2 \\
\text { (15.0 to 21.3) }\end{array}$ & $\begin{array}{l}31690 \\
\text { (25695 to } 37974)\end{array}$ & $\begin{array}{l}11084 \\
(10075 \text { to } 12080)\end{array}$ & $\begin{array}{c}3534 \\
\text { (2925 to 4135) }\end{array}$ & $\begin{array}{l}-6 \cdot 0 \% \\
(-7 \cdot 6 \text { to }-4 \cdot 3)\end{array}$ & $\begin{array}{l}-12 \cdot 6 \% \\
(-14 \cdot 5 \text { to }-10 \cdot 7)\end{array}$ & $\begin{array}{l}-8 \cdot 9 \% \\
(-10 \cdot 1 \text { to }-7 \cdot 6)\end{array}$ \\
\hline China & $\begin{array}{l}141 \cdot 7 \\
(114 \cdot 4 \text { to } 170 \cdot 8)\end{array}$ & $\begin{array}{l}64 \cdot 1 \\
(58 \cdot 2 \text { to } 70 \cdot 1)\end{array}$ & $\begin{array}{l}17 \cdot 2 \\
(14 \cdot 0 \text { to } 20 \cdot 3)\end{array}$ & $\begin{array}{l}31042 \\
\text { (25074 to } 37428)\end{array}$ & $\begin{array}{l}10652 \\
\text { (9667 to } 11643)\end{array}$ & $\begin{array}{c}3233 \\
\text { (2633 to 3815) }\end{array}$ & $\begin{array}{l}-6 \cdot 1 \% \\
(-7 \cdot 8 \text { to }-4 \cdot 3)\end{array}$ & $\begin{array}{l}-13 \cdot 2 \% \\
(-15 \cdot 2 \text { to }-11 \cdot 1)\end{array}$ & $\begin{array}{l}-9 \cdot 2 \% \\
(-10 \cdot 4 \text { to }-7 \cdot 8)\end{array}$ \\
\hline North Korea & $\begin{array}{l}136 \cdot 3 \\
(70 \cdot 2 \text { to } 226 \cdot 7)\end{array}$ & $\begin{array}{l}100 \cdot 5 \\
(67 \cdot 8 \text { to } 144 \cdot 1)\end{array}$ & $\begin{array}{l}77 \cdot 4 \\
(48 \cdot 3 \text { to } 111.9)\end{array}$ & $\begin{array}{c}546 \\
\text { (281 to } 908 \text { ) }\end{array}$ & $\begin{array}{c}386 \\
\text { (260 to 554) }\end{array}$ & $\begin{array}{c}275 \\
\text { (172 to } 398)\end{array}$ & $\begin{array}{l}-2 \cdot 2 \% \\
(-6 \cdot 5 \text { to } 2 \cdot 5)\end{array}$ & $\begin{array}{l}-2 \cdot 6 \% \\
(-7 \cdot 4 \text { to } 2 \cdot 5)\end{array}$ & $\begin{array}{l}-2 \cdot 4 \% \\
(-5 \cdot 6 \text { to } 1 \cdot 1)\end{array}$ \\
\hline $\begin{array}{l}\text { Taiwan } \\
\text { (Province } \\
\text { of China) }\end{array}$ & $\begin{array}{l}24 \cdot 9 \\
(17 \cdot 3 \text { to } 33 \cdot 8)\end{array}$ & $\begin{array}{c}13 \cdot 5 \\
\text { (10.1 to } 17 \cdot 8)\end{array}$ & $\begin{array}{c}7 \cdot 9 \\
\text { (6.1 to } 10 \cdot 2)\end{array}$ & $\begin{array}{c}102 \\
\text { (71 to } 138)\end{array}$ & $\begin{array}{c}46 \\
\text { (34 to } 60)\end{array}$ & $\begin{array}{c}26 \\
\text { (20 to } 33 \text { ) }\end{array}$ & $\begin{array}{l}-4 \cdot 7 \% \\
(-7 \cdot 7 \text { to }-1 \cdot 8)\end{array}$ & $\begin{array}{l}-5 \cdot 3 \% \\
(-9 \cdot 0 \text { to }-1 \cdot 7)\end{array}$ & $\begin{array}{l}-5 \cdot 0 \% \\
(-6 \cdot 6 \text { to }-3 \cdot 2)\end{array}$ \\
\hline South Asia & $\begin{array}{l}480 \cdot 4 \\
(407 \cdot 4 \text { to } 558 \cdot 3)\end{array}$ & $\begin{array}{l}399 \cdot 7 \\
\text { (345.8 to } 467 \cdot 6)\end{array}$ & $\begin{array}{l}310.6 \\
\text { (252.4 to 383.4) }\end{array}$ & $\begin{array}{l}174416 \\
\text { (147914 to 202689) }\end{array}$ & $\begin{array}{l}142624 \\
\text { (123413 to } 166876)\end{array}$ & $\begin{array}{l}107827 \\
\text { (87629 to } 133087)\end{array}$ & $\begin{array}{l}-1 \cdot 4 \% \\
(-3.0 \text { to } 0.3)\end{array}$ & $\begin{array}{l}-2.6 \% \\
(-5.1 \text { to } 0.0)\end{array}$ & $\begin{array}{l}-1 \cdot 9 \% \\
(-3.0 \text { to }-0.8)\end{array}$ \\
\hline Afghanistan & $\begin{array}{l}501 \cdot 0 \\
(324 \cdot 4 \text { to } 739 \cdot 0)\end{array}$ & $\begin{array}{l}716 \cdot 3 \\
(441 \cdot 3 \text { to } 1123 \cdot 4)\end{array}$ & $\begin{array}{l}885 \cdot 0 \\
\text { (508.7 to 1445.1) }\end{array}$ & $\begin{array}{c}3261 \\
\text { (2112 to 4811) }\end{array}$ & $\begin{array}{c}7726 \\
\text { (4760 to } 12117)\end{array}$ & $\begin{array}{l}8794 \\
\text { (5055 to } 14360)\end{array}$ & $\begin{array}{l}2.7 \% \\
(-0.6 \text { to } 5.8)\end{array}$ & $\begin{array}{l}2 \cdot 1 \% \\
(-1.8 \text { to } 5 \cdot 4)\end{array}$ & $\begin{array}{l}2.4 \% \\
\text { (0.1 to } 4.7)\end{array}$ \\
\hline Bangladesh & $\begin{array}{l}551 \cdot 9 \\
(436 \cdot 4 \text { to } 659 \cdot 5)\end{array}$ & $\begin{array}{l}333 \cdot 1 \\
\text { (250.9 to } 427 \cdot 6)\end{array}$ & $\begin{array}{l}242 \cdot 7 \\
(171 \cdot 2 \text { to } 326 \cdot 9)\end{array}$ & $\begin{array}{l}20669 \\
\text { (16345 to 24701) }\end{array}$ & $\begin{array}{l}11327 \\
\text { (8532 to } 14541)\end{array}$ & $\begin{array}{c}7737 \\
\text { (5459 to } 10422 \text { ) }\end{array}$ & $\begin{array}{l}-3 \cdot 9 \% \\
(-6 \cdot 4 \text { to }-1 \cdot 3)\end{array}$ & $\begin{array}{l}-3 \cdot 2 \% \\
(-7 \cdot 0 \text { to } 0.8)\end{array}$ & $\begin{array}{l}-3 \cdot 6 \% \\
(-5 \cdot 1 \text { to }-1 \cdot 9)\end{array}$ \\
\hline Bhutan & $\begin{array}{l}551 \cdot 7 \\
(275 \cdot 0 \text { to } 846 \cdot 5)\end{array}$ & $\begin{array}{l}411 \cdot 2 \\
\text { (204.9 to } 651 \cdot 7)\end{array}$ & $\begin{array}{l}277 \cdot 4 \\
(136 \cdot 7 \text { to } 469 \cdot 2)\end{array}$ & $\begin{array}{c}106 \\
\text { (53 to } 162 \text { ) }\end{array}$ & $\begin{array}{c}59 \\
(30 \text { to } 94)\end{array}$ & $\begin{array}{c}40 \\
\text { (20 to } 68)\end{array}$ & $\begin{array}{l}-2 \cdot 3 \% \\
(-6 \cdot 4 \text { to } 1 \cdot 5)\end{array}$ & $\begin{array}{l}-4 \cdot 0 \% \\
(-8 \cdot 1 \text { to } 0.9)\end{array}$ & $\begin{array}{l}-3 \cdot 0 \% \\
(-5 \cdot 8 \text { to } 0.2)\end{array}$ \\
\hline India & $\begin{array}{l}480 \cdot 8 \\
\text { (384.9 to } 583 \cdot 6)\end{array}$ & $\begin{array}{l}382 \cdot 0 \\
\text { (315.3 to } 472 \cdot 8)\end{array}$ & $\begin{array}{l}281 \cdot 8 \\
\text { (207.0 to 371.2) }\end{array}$ & $\begin{array}{l}128695 \\
\text { (103026 to } 156193)\end{array}$ & $\begin{array}{l}100014 \\
\text { (82553 to 123801) }\end{array}$ & $\begin{array}{l}71792 \\
\text { (52723 to 94564) }\end{array}$ & $\begin{array}{l}-1 \cdot 8 \% \\
(-4 \cdot 0 \text { to } 0 \cdot 6)\end{array}$ & $\begin{array}{l}-3 \cdot 1 \% \\
(-6 \cdot 6 \text { to } 0 \cdot 3)\end{array}$ & $\begin{array}{l}-2 \cdot 3 \% \\
(-3.9 \text { to }-0.8)\end{array}$ \\
\hline \multirow[t]{2}{*}{ Nepal } & $\begin{array}{l}417 \cdot 4 \\
\text { (295.9 to } 540 \cdot 8)\end{array}$ & $\begin{array}{l}365 \cdot 0 \\
(262 \cdot 6 \text { to } 464 \cdot 3)\end{array}$ & $\begin{array}{l}272 \cdot 3 \\
(190 \cdot 9 \text { to } 363 \cdot 5)\end{array}$ & $\begin{array}{c}3012 \\
\text { (2136 to 3903) }\end{array}$ & $\begin{array}{c}2623 \\
\text { (1886 to 3336) }\end{array}$ & $\begin{array}{l}1588 \\
\text { (1113 to 2119) }\end{array}$ & $\begin{array}{l}-1 \cdot 0 \% \\
(-3.6 \text { to } 1 \cdot 5)\end{array}$ & $\begin{array}{l}-3.0 \% \\
(-6.0 \text { to }-0.1)\end{array}$ & $\begin{array}{l}-1 \cdot 9 \% \\
(-3 \cdot 7 \text { to } 0.1)\end{array}$ \\
\hline & & & & & & & & \multicolumn{2}{|c|}{ (Table 1 continues on next page) } \\
\hline
\end{tabular}




\begin{tabular}{|c|c|c|c|c|c|c|c|c|c|}
\hline & \multicolumn{3}{|c|}{ Maternal mortality ratio (per 100000 livebirths) } & \multicolumn{3}{|c|}{ Number of maternal deaths } & \multicolumn{3}{|c|}{$\begin{array}{l}\text { Annualised rate of change in maternal } \\
\text { mortality ratio (\%) }\end{array}$} \\
\hline & 1990 & 2003 & 2013 & 1990 & 2003 & 2013 & $1990-2003$ & $2003-13$ & $1990-2013$ \\
\hline \multicolumn{10}{|c|}{ (Continued from previous page) } \\
\hline Pakistan & $\begin{array}{l}423 \cdot 9 \\
(317 \cdot 2 \text { to } 521 \cdot 6)\end{array}$ & $\begin{array}{l}486 \cdot 5 \\
(360 \cdot 7 \text { to } 595 \cdot 6)\end{array}$ & $\begin{array}{l}400 \cdot 6 \\
(233 \cdot 0 \text { to } 560 \cdot 8)\end{array}$ & $\begin{array}{l}18673 \\
\text { (13973 to } 22976)\end{array}$ & $\begin{array}{l}20875 \\
\text { (15477 to } 25557)\end{array}$ & $\begin{array}{l}17876 \\
(10397 \text { to } 25026)\end{array}$ & $\begin{array}{l}1.1 \% \\
\text { (-1.6 to } 3 \cdot 7)\end{array}$ & $\begin{array}{l}-2.1 \% \\
(-7.7 \text { to } 2 \cdot 4)\end{array}$ & $\begin{array}{l}-0.3 \% \\
(-2 \cdot 9 \text { to } 1.8)\end{array}$ \\
\hline Southeast Asia & $\begin{array}{l}295 \cdot 0 \\
(247 \cdot 5 \text { to } 353 \cdot 4)\end{array}$ & $\begin{array}{l}217 \cdot 4 \\
(180 \cdot 8 \text { to } 266 \cdot 3)\end{array}$ & $\begin{array}{l}154 \cdot 9 \\
(124 \cdot 2 \text { to } 192 \cdot 9)\end{array}$ & $\begin{array}{l}35339 \\
\text { (29644 to } 42340)\end{array}$ & $\begin{array}{l}25637 \\
\text { (21327 to 31404) }\end{array}$ & $\begin{array}{l}18028 \\
\text { (14456 to 22444) }\end{array}$ & $\begin{array}{l}-2 \cdot 3 \% \\
(-3 \cdot 6 \text { to }-1 \cdot 1)\end{array}$ & $\begin{array}{l}-3 \cdot 4 \% \\
(-5 \cdot 4 \text { to }-1 \cdot 6)\end{array}$ & $\begin{array}{l}-2 \cdot 8 \% \\
(-4 \cdot 0 \text { to }-1 \cdot 8)\end{array}$ \\
\hline Cambodia & $\begin{array}{l}355 \cdot 9 \\
(290 \cdot 5 \text { to } 415 \cdot 7)\end{array}$ & $\begin{array}{l}399 \cdot 0 \\
(277 \cdot 9 \text { to } 486 \cdot 8)\end{array}$ & $\begin{array}{l}220 \cdot 9 \\
(155 \cdot 6 \text { to } 286 \cdot 5)\end{array}$ & $\begin{array}{c}1290 \\
\text { (1053 to } 1507)\end{array}$ & $\begin{array}{c}1355 \\
\text { (944 to } 1654)\end{array}$ & $\begin{array}{c}862 \\
(607 \text { to } 1118)\end{array}$ & $\begin{array}{l}0.8 \% \\
(-1.8 \text { to } 2 \cdot 8)\end{array}$ & $\begin{array}{l}-5 \cdot 9 \% \\
(-9 \cdot 3 \text { to }-2 \cdot 9)\end{array}$ & $\begin{array}{l}-2 \cdot 1 \% \\
(-3 \cdot 6 \text { to }-0.6\end{array}$ \\
\hline Indonesia & $\begin{array}{l}368 \cdot 3 \\
(311 \cdot 6 \text { to } 432 \cdot 9)\end{array}$ & $\begin{array}{l}262 \cdot 0 \\
(224 \cdot 3 \text { to } 308 \cdot 2)\end{array}$ & $\begin{array}{l}199 \cdot 3 \\
(149 \cdot 4 \text { to } 257 \cdot 4)\end{array}$ & $\begin{array}{l}16519 \\
(13975 \text { to } 19416)\end{array}$ & $\begin{array}{l}12734 \\
(10902 \text { to } 14982)\end{array}$ & $\begin{array}{c}9352 \\
7010 \text { to } 12079)\end{array}$ & $\begin{array}{l}-2 \cdot 6 \% \\
(-4 \cdot 2 \text { to }-1 \cdot 0)\end{array}$ & $\begin{array}{l}-2 \cdot 8 \% \\
(-6 \cdot 1 \text { to } 0.0)\end{array}$ & $\begin{array}{l}-2 \cdot 7 \% \\
(-4 \cdot 3 \text { to }-1 \cdot 4)\end{array}$ \\
\hline Laos & $\begin{array}{l}514 \cdot 4 \\
(276 \cdot 7 \text { to } 767 \cdot 0)\end{array}$ & $\begin{array}{l}490 \cdot 7 \\
(251 \cdot 3 \text { to } 779 \cdot 6)\end{array}$ & $\begin{array}{l}303 \cdot 8 \\
(154 \cdot 7 \text { to } 521 \cdot 5)\end{array}$ & $\begin{array}{c}942 \\
\text { (506 to } 1404)\end{array}$ & $\begin{array}{c}814 \\
\text { (417 to } 1293)\end{array}$ & $\begin{array}{c}543 \\
\text { (277 to } 932)\end{array}$ & $\begin{array}{l}-0.4 \% \\
(-4 \cdot 1 \text { to } 2 \cdot 7)\end{array}$ & $\begin{array}{l}-4 \cdot 8 \% \\
(-8 \cdot 3 \text { to }-1 \cdot 1)\end{array}$ & $\begin{array}{l}-2 \cdot 3 \% \\
(-4 \cdot 7 \text { to } 0.3)\end{array}$ \\
\hline Malaysia & $\begin{array}{l}101 \cdot 6 \\
(84 \cdot 3 \text { to } 120 \cdot 3)\end{array}$ & $\begin{array}{l}78 \cdot 4 \\
(70 \cdot 7 \text { to } 87.5)\end{array}$ & $\begin{array}{l}55 \cdot 7 \\
\text { (43.1 to } 70 \cdot 6)\end{array}$ & $\begin{array}{c}522 \\
\text { (433 to } 617)\end{array}$ & $\begin{array}{c}364 \\
\text { (328 to } 406)\end{array}$ & $\begin{array}{c}291 \\
\text { (226 to } 369)\end{array}$ & $\begin{array}{l}-2.0 \% \\
(-3.5 \text { to }-0.4)\end{array}$ & $\begin{array}{l}-3.5 \% \\
(-6.0 \text { to }-0.8)\end{array}$ & $\begin{array}{l}-2.6 \% \\
(-3.9 \text { to }-1 \cdot 3)\end{array}$ \\
\hline Maldives & $\begin{array}{l}292 \cdot 3 \\
(240 \cdot 8 \text { to } 355 \cdot 1)\end{array}$ & $\begin{array}{l}95 \cdot 4 \\
\text { (78.7 to 111.6) }\end{array}$ & $\begin{array}{l}51 \cdot 8 \\
(38.6 \text { to } 67.0)\end{array}$ & $\begin{array}{c}23 \\
\text { (19 to } 28)\end{array}$ & (5 to 7$)^{6}$ & $(3 \text { to } 5)^{4}$ & $\begin{array}{l}-8 \cdot 6 \% \\
(-10 \cdot 3 \text { to }-6 \cdot 7)\end{array}$ & $\begin{array}{l}-6 \cdot 2 \% \\
(-9.5 \text { to }-3.0)\end{array}$ & $\begin{array}{l}-7 \cdot 5 \% \\
(-9 \cdot 1 \text { to }-6 \cdot 0)\end{array}$ \\
\hline Myanmar & $\begin{array}{l}897 \cdot 3 \\
(513 \cdot 3 \text { to } 1460 \cdot 4)\end{array}$ & $\begin{array}{l}645 \cdot 6 \\
\text { (332.2 to } 1145 \cdot 2)\end{array}$ & $\begin{array}{l}390 \cdot 9 \\
(196 \cdot 3 \text { to } 731 \cdot 7)\end{array}$ & $\begin{array}{l}9465 \\
\text { (5414 to } 15405)\end{array}$ & $\begin{array}{l}6108 \\
\text { (3144 to } 10835)\end{array}$ & $\begin{array}{c}3531 \\
\text { (1773 to 6609) }\end{array}$ & $\begin{array}{l}-2.6 \% \\
(-6.1 \text { to } 0.6)\end{array}$ & $\begin{array}{l}-5 \cdot 1 \% \\
(-8 \cdot 8 \text { to }-1 \cdot 0)\end{array}$ & $\begin{array}{l}-3.7 \% \\
(-6.0 \text { to }-0.9\end{array}$ \\
\hline Philippines & $\begin{array}{l}116 \cdot 3 \\
(103 \cdot 4 \text { to } 130 \cdot 2)\end{array}$ & $\begin{array}{l}81.5 \\
\text { (72.0 to } 91.5)\end{array}$ & $\begin{array}{l}80.9 \\
(54.9 \text { to } 115 \cdot 0)\end{array}$ & $\begin{array}{c}2374 \\
\text { (2112 to } 2658)\end{array}$ & $\begin{array}{c}1876 \\
\text { (1657 to 2105) }\end{array}$ & $\begin{array}{c}1959 \\
\text { (1328 to 2784) }\end{array}$ & $\begin{array}{l}-2.7 \% \\
(-3.9 \text { to }-1.5)\end{array}$ & $\begin{array}{l}-0.2 \% \\
(-4 \cdot 3 \text { to } 3.5)\end{array}$ & $\begin{array}{l}-1.6 \% \\
(-3 \cdot 3 \text { to }-0.1)\end{array}$ \\
\hline Sri Lanka & $\begin{array}{l}73.6 \\
\text { (61.8 to 89.0) }\end{array}$ & $\begin{array}{l}47.9 \\
\text { (38.9 to } 56 \cdot 7 \text { ) }\end{array}$ & $\begin{array}{l}30 \cdot 9 \\
(20 \cdot 7 \text { to } 43 \cdot 4)\end{array}$ & $\begin{array}{c}257 \\
\text { (216 to } 311)\end{array}$ & $\begin{array}{c}178 \\
\text { (144 to 211) }\end{array}$ & $\begin{array}{c}116 \\
\text { (77 to } 162 \text { ) }\end{array}$ & $\begin{array}{l}-3 \cdot 3 \% \\
(-5 \cdot 3 \text { to }-1 \cdot 7)\end{array}$ & $\begin{array}{l}-4.5 \% \\
(-8.6 \text { to }-0.6)\end{array}$ & $\begin{array}{l}-3 \cdot 8 \% \\
(-5 \cdot 9 \text { to }-2 \cdot 1)\end{array}$ \\
\hline Thailand & $\begin{array}{l}42 \cdot 6 \\
\text { (36.1 to } 50 \cdot 3)\end{array}$ & $\begin{array}{l}89 \cdot 6 \\
(75 \cdot 9 \text { to } 104 \cdot 4)\end{array}$ & $\begin{array}{l}69.5 \\
(47 \cdot 3 \text { to } 98 \cdot 7)\end{array}$ & $\begin{array}{c}456 \\
\text { (386 to 538) }\end{array}$ & $\begin{array}{c}766 \\
\text { (648 to 892) }\end{array}$ & $\begin{array}{c}481 \\
\text { (328 to } 684)\end{array}$ & $\begin{array}{l}5.7 \% \\
\text { (3.8 to } 7.5)\end{array}$ & $\begin{array}{l}-2 \cdot 7 \% \\
(-6.6 \text { to } 1 \cdot 4)\end{array}$ & $\begin{array}{l}2.1 \% \\
(0.3 \text { to } 3.9)\end{array}$ \\
\hline Timor-Leste & $\begin{array}{l}632 \cdot 8 \\
(490 \cdot 8 \text { to } 781 \cdot 3)\end{array}$ & $\begin{array}{l}430 \cdot 2 \\
\text { (361.6 to } 498 \cdot 6)\end{array}$ & $\begin{array}{l}223 \cdot 4 \\
\text { (175.5 to 275.9) }\end{array}$ & $\begin{array}{c}215 \\
\text { (167 to 266) }\end{array}$ & $\begin{array}{c}156 \\
\text { (131 to } 181)\end{array}$ & $\begin{array}{c}89 \\
\text { (70 to } 110)\end{array}$ & $\begin{array}{l}-2.9 \% \\
(-4.9 \text { to }-0.9)\end{array}$ & $\begin{array}{l}-6 \cdot 6 \% \\
(-9.0 \text { to }-4.2)\end{array}$ & $\begin{array}{l}-4 \cdot 5 \% \\
(-6 \cdot 0 \text { to }-3 \cdot 1)\end{array}$ \\
\hline Vietnam & $\begin{array}{l}174 \cdot 5 \\
(124 \cdot 5 \text { to } 239 \cdot 1)\end{array}$ & $\begin{array}{l}88 \cdot 5 \\
\text { (59.4 to } 122 \cdot 0)\end{array}$ & $\begin{array}{l}56 \cdot 6 \\
\text { (34.1 to } 89.5)\end{array}$ & $\begin{array}{c}3275 \\
\text { (2337 to 4487) }\end{array}$ & $\begin{array}{c}1281 \\
\text { (860 to } 1766)\end{array}$ & $\begin{array}{c}800 \\
\text { (482 to } 1265)\end{array}$ & $\begin{array}{l}-5 \cdot 2 \% \\
(-8 \cdot 3 \text { to }-2 \cdot 2)\end{array}$ & $\begin{array}{l}-4.6 \% \\
(-9 \cdot 1 \text { to } 0.0)\end{array}$ & $\begin{array}{l}-5.0 \% \\
(-7.5 \text { to }-2 \cdot 3)\end{array}$ \\
\hline Australasia & $\begin{array}{c}8.1 \\
\text { (7.1 to } 9.2)\end{array}$ & $\begin{array}{c}5 \cdot 9 \\
(5 \cdot 2 \text { to } 6 \cdot 7)\end{array}$ & $\begin{array}{c}5.5 \\
(4.5 \text { to } 6.6)\end{array}$ & $\begin{array}{c}26 \\
(22 \text { to } 29)\end{array}$ & $\begin{array}{c}19 \\
\text { (17 to } 22)\end{array}$ & $\begin{array}{c}21 \\
\text { (17 to } 25)\end{array}$ & $\begin{array}{l}-2 \cdot 4 \% \\
(-3 \cdot 7 \text { to }-1 \cdot 0)\end{array}$ & $\begin{array}{l}-0.7 \% \\
(-2 \cdot 7 \text { to } 1 \cdot 3)\end{array}$ & $\begin{array}{l}-1.7 \% \\
(-2.6 \text { to }-0.6)\end{array}$ \\
\hline Australia & $\begin{array}{c}7 \cdot 0 \\
(6 \cdot 0 \text { to } 8 \cdot 2)\end{array}$ & $\begin{array}{c}5 \cdot 1 \\
(4 \cdot 4 \text { to } 6 \cdot 0)\end{array}$ & $\begin{array}{c}4.8 \\
(3.7 \text { to } 5.9)\end{array}$ & $\begin{array}{c}18 \\
\text { (16 to } 21)\end{array}$ & $\begin{array}{c}14 \\
\text { (12 to } 16)\end{array}$ & $\begin{array}{c}15 \\
\text { (12 to } 18)\end{array}$ & $\begin{array}{l}-2 \cdot 5 \% \\
(-4 \cdot 1 \text { to }-0.8)\end{array}$ & $\begin{array}{l}-0.7 \% \\
(-3 \cdot 2 \text { to } 2 \cdot 0)\end{array}$ & $\begin{array}{l}-1 \cdot 7 \% \\
(-3 \cdot 0 \text { to }-0.5)\end{array}$ \\
\hline New Zealand & $\begin{array}{l}12 \cdot 6 \\
\text { (10.3 to } 15 \cdot 2)\end{array}$ & $\begin{array}{c}9 \cdot 4 \\
\text { (7.9 to } 11 \cdot 3)\end{array}$ & $\begin{array}{c}9 \cdot 3 \\
\text { (7.2 to } 12 \cdot 1)\end{array}$ & $\begin{array}{r}7 \\
\text { (6 to } 9)^{7}\end{array}$ & (5 to 7$)^{6}$ & (4 to 7$)^{6}$ & $\begin{array}{l}-2 \cdot 2 \% \\
(-4 \cdot 2 \text { to }-0 \cdot 3)\end{array}$ & $\begin{array}{l}-0.1 \% \\
(-3 \cdot 0 \text { to } 2 \cdot 7)\end{array}$ & $\begin{array}{l}-1 \cdot 3 \% \\
(-2 \cdot 8 \text { to } 0.1)\end{array}$ \\
\hline Caribbean & $\begin{array}{l}208 \cdot 3 \\
(165 \cdot 9 \text { to } 248 \cdot 8)\end{array}$ & $\begin{array}{l}213 \cdot 1 \\
\text { (161.4 to 272.2) }\end{array}$ & $\begin{array}{l}150 \cdot 0 \\
\text { (110.1 to 206.7) }\end{array}$ & $\begin{array}{c}1664 \\
\text { (1325 to } 1987)\end{array}$ & $\begin{array}{c}1602 \\
\text { (1214 to 2047) }\end{array}$ & $\begin{array}{c}1075 \\
\text { (788 to } 1480)\end{array}$ & $\begin{array}{l}0.1 \% \\
\text { (-1.5 to } 1.7)\end{array}$ & $\begin{array}{l}-3 \cdot 5 \% \\
(-6 \cdot 1 \text { to }-1 \cdot 0)\end{array}$ & $\begin{array}{l}-1.5 \% \\
(-2.6 \text { to }-0.1)\end{array}$ \\
\hline $\begin{array}{l}\text { Antigua and } \\
\text { Barbuda }\end{array}$ & $\begin{array}{l}54 \cdot 4 \\
\text { (40.1 to } 69 \cdot 4)\end{array}$ & $\begin{array}{l}50 \cdot 8 \\
(40 \cdot 1 \text { to } 64 \cdot 2)\end{array}$ & $\begin{array}{l}42 \cdot 0 \\
(27 \cdot 9 \text { to } 62 \cdot 3)\end{array}$ & (1 to 1$)^{1}$ & $(1 \text { to } 1)^{1}$ & $(0 \text { to } 1)^{1}$ & $\begin{array}{l}-0.5 \% \\
(-3 \cdot 2 \text { to } 2 \cdot 1)\end{array}$ & $\begin{array}{l}-2 \cdot 0 \% \\
(-6 \cdot 4 \text { to } 2 \cdot 7)\end{array}$ & $\begin{array}{l}-1 \cdot 2 \% \\
(-3 \cdot 1 \text { to } 1 \cdot 1)\end{array}$ \\
\hline Barbados & $\begin{array}{l}69.4 \\
(54.8 \text { to } 87 \cdot 4)\end{array}$ & $\begin{array}{l}62 \cdot 3 \\
(50 \cdot 4 \text { to } 75 \cdot 0)\end{array}$ & $\begin{array}{l}49 \cdot 9 \\
\text { (34.3 to } 70 \cdot 7)\end{array}$ & $(2 \text { to } 4)^{3}$ & $(2 \text { to } 3)^{2}$ & $(1 \text { to } 3)^{2}$ & $\begin{array}{l}-0.8 \% \\
(-3.0 \text { to } 1.4)\end{array}$ & $\begin{array}{l}-2 \cdot 3 \% \\
(-6 \cdot 2 \text { to } 1 \cdot 7)\end{array}$ & $\begin{array}{l}-1 \cdot 5 \% \\
(-3 \cdot 2 \text { to } 0.4)\end{array}$ \\
\hline Belize & $\begin{array}{l}32 \cdot 1 \\
(26 \cdot 2 \text { to } 39 \cdot 5)\end{array}$ & $\begin{array}{l}42 \cdot 5 \\
(34.9 \text { to } 51 \cdot 6)\end{array}$ & $\begin{array}{l}55.5 \\
\text { (37.6 to } 78.9)\end{array}$ & $(2 \text { to } 3)^{2}$ & $(2 \text { to } 4)^{3}$ & $(3 \text { to } 6)^{4}$ & $\begin{array}{l}2 \cdot 2 \% \\
(0.1 \text { to } 4 \cdot 2)\end{array}$ & $\begin{array}{l}2.5 \% \\
(-1.4 \text { to } 6 \cdot 3)\end{array}$ & $\begin{array}{l}2 \cdot 3 \% \\
(0 \cdot 3 \text { to } 4 \cdot 1)\end{array}$ \\
\hline Cuba & $\begin{array}{l}71 \cdot 1 \\
(59 \cdot 6 \text { to } 87 \cdot 0)\end{array}$ & $\begin{array}{l}60 \cdot 6 \\
\text { (52.4 to } 70.2)\end{array}$ & $\begin{array}{l}39.8 \\
(31 \cdot 5 \text { to } 49.5)\end{array}$ & $\begin{array}{c}123 \\
\text { (103 to } 150)\end{array}$ & $\begin{array}{c}82 \\
\text { (71 to } 95)\end{array}$ & $\begin{array}{c}44 \\
\text { (35 to } 54)\end{array}$ & $\begin{array}{l}-1.2 \% \\
(-3.0 \text { to } 0.4)\end{array}$ & $\begin{array}{l}-4 \cdot 3 \% \\
(-6 \cdot 9 \text { to }-1 \cdot 6)\end{array}$ & $\begin{array}{l}-2.5 \% \\
(-3.8 \text { to }-1.2)\end{array}$ \\
\hline Dominica & $\begin{array}{l}50 \cdot 2 \\
(39 \cdot 2 \text { to } 65 \cdot 9)\end{array}$ & $\begin{array}{l}41 \cdot 4 \\
\text { (32.4 to } 52 \cdot 2)\end{array}$ & $\begin{array}{l}36 \cdot 1 \\
(23 \cdot 2 \text { to } 52 \cdot 7)\end{array}$ & (1 to 1$)^{1}$ & (0 to 1$)^{1}$ & $\begin{array}{l}0 \\
(0 \text { to } 1)^{0}\end{array}$ & $\begin{array}{l}-1 \cdot 5 \% \\
(-4 \cdot 2 \text { to } 1 \cdot 0)\end{array}$ & $\begin{array}{l}-1.5 \% \\
(-5.9 \text { to } 2.6)\end{array}$ & $\begin{array}{l}-1.5 \% \\
(-3.6 \text { to } 0.6)\end{array}$ \\
\hline $\begin{array}{l}\text { Dominican } \\
\text { Republic }\end{array}$ & $\begin{array}{l}73 \cdot 8 \\
\text { (62.8 to } 85.8)\end{array}$ & $\begin{array}{l}60 \cdot 5 \\
(52 \cdot 2 \text { to } 69 \cdot 8)\end{array}$ & $\begin{array}{l}40 \cdot 8 \\
(28 \cdot 9 \text { to } 55 \cdot 8)\end{array}$ & $\begin{array}{c}164 \\
(139 \text { to } 191)\end{array}$ & $\begin{array}{c}138 \\
\text { (119 to } 159)\end{array}$ & $\begin{array}{c}90 \\
\text { (64 to } 124)\end{array}$ & $\begin{array}{l}-1 \cdot 5 \% \\
(-2 \cdot 9 \text { to } 0.0)\end{array}$ & $\begin{array}{l}-4 \cdot 1 \% \\
(-7.6 \text { to }-0.8)\end{array}$ & $\begin{array}{l}-2 \cdot 6 \% \\
(-4 \cdot 2 \text { to }-1 \cdot 1)\end{array}$ \\
\hline Grenada & $\begin{array}{l}47 \cdot 7 \\
(37.6 \text { to } 62 \cdot 4)\end{array}$ & $\begin{array}{l}62.5 \\
(50.6 \text { to } 76 \cdot 6)\end{array}$ & $\begin{array}{l}56 \cdot 7 \\
(41 \cdot 0 \text { to } 76 \cdot 9)\end{array}$ & (1 to 2$)^{1}$ & $(1 \text { to } 1)^{1}$ & $(1 \text { to } 2)^{1}$ & $\begin{array}{l}2.1 \% \\
(-0.2 \text { to } 4.5)\end{array}$ & $\begin{array}{l}-1 \cdot 1 \% \\
(-4 \cdot 7 \text { to } 2 \cdot 4)\end{array}$ & $\begin{array}{l}0.7 \% \\
(-1.0 \text { to } 2 \cdot 4)\end{array}$ \\
\hline Guyana & $\begin{array}{l}118.8 \\
(98 \cdot 5 \text { to } 142 \cdot 0)\end{array}$ & $\begin{array}{l}138.9 \\
\text { (111.4 to } 169.2)\end{array}$ & $\begin{array}{l}118 \cdot 1 \\
\text { (75.8 to } 179 \cdot 4)\end{array}$ & $\begin{array}{c}21 \\
\text { (17 to } 25)\end{array}$ & $\begin{array}{c}25 \\
\text { (20 to } 30 \text { ) }\end{array}$ & $\begin{array}{c}20 \\
(13 \text { to } 30)\end{array}$ & $\begin{array}{l}1.2 \% \\
\text { (-1.0 to } 3.3)\end{array}$ & $\begin{array}{l}-1 \cdot 8 \% \\
\text { (-6.1 to } 2 \cdot 4)\end{array}$ & $\begin{array}{l}-0.1 \% \\
(-2 \cdot 1 \text { to } 2 \cdot 0)\end{array}$ \\
\hline Haiti & $\begin{array}{l}492 \cdot 4 \\
(363 \cdot 4 \text { to } 619 \cdot 7)\end{array}$ & $\begin{array}{l}495 \cdot 7 \\
\text { (351.1 to 662.0) }\end{array}$ & $\begin{array}{l}333 \cdot 0 \\
\text { (219.1 to } 480 \cdot 1)\end{array}$ & $\begin{array}{c}1290 \\
\text { (952 to } 1624)\end{array}$ & $\begin{array}{c}1289 \\
\text { (913 to } 1722 \text { ) }\end{array}$ & $\begin{array}{c}868 \\
\text { (571 to } 1251 \text { ) }\end{array}$ & $\begin{array}{l}0.0 \% \\
(-2 \cdot 0 \text { to } 2 \cdot 1)\end{array}$ & $\begin{array}{l}-4 \cdot 0 \% \\
(-7 \cdot 2 \text { to }-1 \cdot 0)\end{array}$ & $\begin{array}{l}-1 \cdot 7 \% \\
(-3 \cdot 2 \text { to }-0.1)\end{array}$ \\
\hline Jamaica & $\begin{array}{l}44 \cdot 0 \\
(32 \cdot 4 \text { to } 58 \cdot 1)\end{array}$ & $\begin{array}{l}59 \cdot 4 \\
(48 \cdot 6 \text { to } 71 \cdot 2)\end{array}$ & $\begin{array}{l}44 \cdot 7 \\
(29 \cdot 7 \text { to } 66 \cdot 0)\end{array}$ & $\begin{array}{c}27 \\
\text { (20 to } 36)\end{array}$ & $\begin{array}{c}33 \\
\text { (27 to } 40)\end{array}$ & $\begin{array}{c}23 \\
\text { (15 to } 34)\end{array}$ & $\begin{array}{l}2 \cdot 3 \% \\
(-0.2 \text { to } 5 \cdot 0)\end{array}$ & $\begin{array}{l}-3.0 \% \\
(-7.0 \text { to } 1.2)\end{array}$ & $\begin{array}{l}0.0 \% \\
(-2 \cdot 0 \text { to } 2 \cdot 1)\end{array}$ \\
\hline Saint Lucia & $\begin{array}{l}52 \cdot 0 \\
(40 \cdot 8 \text { to } 68 \cdot 7)\end{array}$ & $\begin{array}{l}44 \cdot 4 \\
(35 \cdot 5 \text { to } 54 \cdot 3)\end{array}$ & $\begin{array}{l}41.0 \\
(28.0 \text { to } 58.8)\end{array}$ & $(2 \text { to } 3)^{2}$ & $(1 \text { to } 2)^{1}$ & $(1 \text { to } 2)^{1}$ & $\begin{array}{l}-1 \cdot 2 \% \\
(-3 \cdot 9 \text { to } 1 \cdot 3)\end{array}$ & $\begin{array}{l}-0.9 \% \\
(-4 \cdot 6 \text { to } 3 \cdot 2)\end{array}$ & $\begin{array}{l}-1 \cdot 1 \% \\
(-3 \cdot 1 \text { to } 0.7)\end{array}$ \\
\hline
\end{tabular}




\begin{tabular}{|c|c|c|c|c|c|c|c|c|c|}
\hline & \multicolumn{3}{|c|}{ Maternal mortality ratio (per 100000 livebirths) } & \multicolumn{3}{|c|}{ Number of maternal deaths } & \multicolumn{3}{|c|}{$\begin{array}{l}\text { Annualised rate of change in maternal } \\
\text { mortality ratio }(\%)\end{array}$} \\
\hline & 1990 & 2003 & 2013 & 1990 & 2003 & 2013 & 1990-2003 & $2003-13$ & 1990-2013 \\
\hline \multicolumn{10}{|c|}{ (Continued from previous page) } \\
\hline $\begin{array}{l}\text { Saint Vincent } \\
\text { and the } \\
\text { Grenadines }\end{array}$ & $\begin{array}{l}45 \cdot 2 \\
(33 \cdot 3 \text { to } 60 \cdot 8)\end{array}$ & $\begin{array}{l}65 \cdot 7 \\
(54 \cdot 0 \text { to } 81 \cdot 7)\end{array}$ & $\begin{array}{l}60 \cdot 1 \\
(43 \cdot 7 \text { to } 80 \cdot 8)\end{array}$ & (1 to 2$)^{1}$ & $(1 \text { to } 2)^{1}$ & $(1 \text { to } 1)^{1}$ & $\begin{array}{l}2.9 \% \\
(0.2 \text { to } 5 \cdot 7)\end{array}$ & $\begin{array}{l}-1 \cdot 0 \% \\
(-4 \cdot 6 \text { to } 2 \cdot 3)\end{array}$ & $\begin{array}{l}1.2 \% \\
(-0.7 \text { to } 3 \cdot 2)\end{array}$ \\
\hline Suriname & $\begin{array}{l}76 \cdot 8 \\
(62 \cdot 3 \text { to } 93 \cdot 2)\end{array}$ & $\begin{array}{l}88 \cdot 2 \\
(71 \cdot 3 \text { to } 106 \cdot 5)\end{array}$ & $\begin{array}{l}65 \cdot 2 \\
(44 \cdot 2 \text { to } 91 \cdot 3)\end{array}$ & (6 to 9$)^{7}$ & $\begin{array}{r}9 \\
\text { (7 to } 11)\end{array}$ & $\begin{array}{r}6 \\
\text { (4 to } 9)^{6}\end{array}$ & $\begin{array}{l}1.1 \% \\
\text { (-1.1 to } 3 \cdot 2)\end{array}$ & $\begin{array}{l}-3 \cdot 1 \% \\
(-7 \cdot 6 \text { to } 1.0)\end{array}$ & $\begin{array}{l}-0.8 \% \\
(-2 \cdot 6 \text { to } 1 \cdot 1)\end{array}$ \\
\hline The Bahamas & $\begin{array}{l}63 \cdot 1 \\
(48.0 \text { to } 84.0)\end{array}$ & $\begin{array}{l}71 \cdot 8 \\
(57 \cdot 5 \text { to } 90 \cdot 2)\end{array}$ & $\begin{array}{l}60 \cdot 3 \\
\text { (38.8 to } 91 \cdot 2)\end{array}$ & $\begin{array}{l}{ }^{4} \\
(3 \text { to } 5)^{4}\end{array}$ & $\begin{array}{l}{ }^{4} \\
\text { (3 to } 5)^{4}\end{array}$ & $\begin{array}{l}{ }^{4} \\
(2 \text { to } 5)^{4}\end{array}$ & $\begin{array}{l}1.0 \% \\
(-1.7 \text { to } 3 \cdot 5)\end{array}$ & $\begin{array}{l}-1 \cdot 9 \% \\
(-6.5 \text { to } 2 \cdot 4)\end{array}$ & $\begin{array}{l}-0 \cdot 3 \% \\
(-2 \cdot 4 \text { to } 2 \cdot 1)\end{array}$ \\
\hline $\begin{array}{l}\text { Trinidad and } \\
\text { Tobago }\end{array}$ & $\begin{array}{l}72 \cdot 3 \\
(61 \cdot 5 \text { to } 84 \cdot 3)\end{array}$ & $\begin{array}{l}64 \cdot 4 \\
(54 \cdot 1 \text { to } 75 \cdot 8)\end{array}$ & $\begin{array}{l}49 \cdot 7 \\
(36 \cdot 4 \text { to } 65 \cdot 6)\end{array}$ & $\begin{array}{c}17 \\
(14 \text { to } 20)\end{array}$ & $\begin{array}{c}13 \\
\text { (11 to } 15)\end{array}$ & $\begin{array}{r}10 \\
\text { (7 to } 13)\end{array}$ & $\begin{array}{l}-0.9 \% \\
(-2.6 \text { to } 0.9)\end{array}$ & $\begin{array}{l}-2 \cdot 7 \% \\
(-5 \cdot 8 \text { to } 0.5)\end{array}$ & $\begin{array}{l}-1 \cdot 7 \% \\
(-3 \cdot 1 \text { to }-0.2)\end{array}$ \\
\hline Central Europe & $\begin{array}{l}48 \cdot 9 \\
(45 \cdot 4 \text { to } 53 \cdot 0)\end{array}$ & $\begin{array}{l}15 \cdot 4 \\
(14 \cdot 1 \text { to } 16 \cdot 5)\end{array}$ & $\begin{array}{l}8 \cdot 8 \\
\text { (7.5 to } 10 \cdot 1)\end{array}$ & $\begin{array}{c}790 \\
\text { (734 to } 856)\end{array}$ & $\begin{array}{c}189 \\
(173 \text { to } 203)\end{array}$ & $\begin{array}{c}112 \\
\text { (95 to } 128)\end{array}$ & $\begin{array}{l}-8.9 \% \\
(-9.7 \text { to }-8.2)\end{array}$ & $\begin{array}{l}-5 \cdot 6 \% \\
(-7 \cdot 1 \text { to }-4 \cdot 1)\end{array}$ & $\begin{array}{l}-7 \cdot 4 \% \\
(-8 \cdot 2 \text { to }-6 \cdot 8)\end{array}$ \\
\hline Albania & $\begin{array}{l}35 \cdot 3 \\
(29 \cdot 5 \text { to } 41 \cdot 6)\end{array}$ & $\begin{array}{l}13 \cdot 2 \\
\text { (10.8 to } 16 \cdot 1)\end{array}$ & $\begin{array}{c}7 \cdot 3 \\
\text { (4.9 to } 10 \cdot 2 \text { ) }\end{array}$ & $\begin{array}{c}30 \\
\text { (25 to 35) }\end{array}$ & $\begin{array}{r}6 \\
\text { (5 to } 8)^{6}\end{array}$ & (2 to 4$)^{3}$ & $\begin{array}{l}-7 \cdot 6 \% \\
(-9 \cdot 7 \text { to }-5 \cdot 5)\end{array}$ & $\begin{array}{l}-6 \cdot 1 \% \\
(-10 \cdot 4 \text { to } \\
-2 \cdot 2)\end{array}$ & $\begin{array}{l}-6.9 \% \\
(-8.7 \text { to }-5.2)\end{array}$ \\
\hline $\begin{array}{l}\text { Bosnia and } \\
\text { Herzegovina }\end{array}$ & $\begin{array}{l}38.8 \\
(31 \cdot 2 \text { to } 47 \cdot 0)\end{array}$ & $\begin{array}{l}20 \cdot 4 \\
(14 \cdot 8 \text { to } 27 \cdot 6)\end{array}$ & $\begin{array}{c}11 \cdot 0 \\
\text { (7.7 to } 15 \cdot 3)\end{array}$ & $\begin{array}{c}23 \\
\text { (19 to } 28)\end{array}$ & (5 to 9) & (3 to 5$)^{4}$ & $\begin{array}{l}-5 \cdot 0 \% \\
(-7 \cdot 8 \text { to }-2 \cdot 3)\end{array}$ & $\begin{array}{l}-6 \cdot 3 \% \\
(-10 \cdot 1 \text { to } \\
-2 \cdot 5)\end{array}$ & $\begin{array}{l}-5 \cdot 5 \% \\
(-7 \cdot 2 \text { to }-3 \cdot 8)\end{array}$ \\
\hline Bulgaria & $\begin{array}{l}44 \cdot 3 \\
\text { (38.8 to } 50 \cdot 7)\end{array}$ & $\begin{array}{l}29 \cdot 2 \\
\text { (24.9 to 33.7) }\end{array}$ & $\begin{array}{l}14 \cdot 8 \\
(12 \cdot 0 \text { to } 18 \cdot 2)\end{array}$ & $\begin{array}{c}43 \\
\text { (37 to } 49)\end{array}$ & $\begin{array}{c}22 \\
\text { (18 to } 25)\end{array}$ & $\begin{array}{r}11 \\
\text { (9 to } 13)\end{array}$ & $\begin{array}{l}-3 \cdot 2 \% \\
(-4 \cdot 8 \text { to }-1 \cdot 7)\end{array}$ & $\begin{array}{l}-6 \cdot 8 \% \\
(-9 \cdot 0 \text { to }-4 \cdot 5)\end{array}$ & $\begin{array}{l}-4 \cdot 8 \% \\
(-5 \cdot 7 \text { to }-3 \cdot 8)\end{array}$ \\
\hline Croatia & $\begin{array}{l}16 \cdot 9 \\
(14 \cdot 1 \text { to } 20 \cdot 1)\end{array}$ & $\begin{array}{l}12 \cdot 7 \\
(10 \cdot 5 \text { to } 14.9)\end{array}$ & $\begin{array}{c}9.9 \\
\text { (7.9 to } 12 \cdot 3)\end{array}$ & $\begin{array}{r}9 \\
\text { (7 to 11) }\end{array}$ & $(4 \text { to } 6)^{5}$ & $\begin{array}{l}{ }^{4} \\
\text { (3 to 5) }\end{array}$ & $\begin{array}{l}-2.2 \% \\
(-4.0 \text { to }-0.5)\end{array}$ & $\begin{array}{l}-2.5 \% \\
(-4.9 \text { to } 0.0)\end{array}$ & $\begin{array}{l}-2 \cdot 3 \% \\
(-3 \cdot 6 \text { to }-1 \cdot 1)\end{array}$ \\
\hline $\begin{array}{l}\text { Czech } \\
\text { Republic }\end{array}$ & $\begin{array}{l}18 \cdot 1 \\
(15 \cdot 2 \text { to } 21 \cdot 4)\end{array}$ & $\begin{array}{c}7.0 \\
(5.8 \text { to } 8.4)\end{array}$ & $\begin{array}{c}5 \cdot 3 \\
\text { (4.1 to } 6 \cdot 7)\end{array}$ & $\begin{array}{c}22 \\
(18 \text { to } 26)\end{array}$ & $\begin{array}{r}7 \\
\text { (6 to } 9)^{2}\end{array}$ & $\begin{array}{r}{ }^{6} \\
\text { (5 to } 8)^{-}\end{array}$ & $\begin{array}{l}-7 \cdot 3 \% \\
(-9 \cdot 2 \text { to }-5 \cdot 4)\end{array}$ & $\begin{array}{l}-2.8 \% \\
(-5.6 \text { to }-0.2)\end{array}$ & $\begin{array}{l}-5 \cdot 3 \% \\
(-6 \cdot 6 \text { to }-4 \cdot 1)\end{array}$ \\
\hline Hungary & $\begin{array}{l}19.0 \\
(16.0 \text { to } 22.5)\end{array}$ & $\begin{array}{c}9.2 \\
\text { (7.6 to } 11.0)\end{array}$ & $\begin{array}{c}8.5 \\
\text { (6.3 to } 10 \cdot 7)\end{array}$ & $\begin{array}{c}24 \\
(20 \text { to } 28)\end{array}$ & $\begin{array}{r}9 \\
\text { (7 to 11) }\end{array}$ & $\begin{array}{r}9 \\
\text { (6 to } 11)\end{array}$ & $\begin{array}{l}-5 \cdot 6 \% \\
(-7 \cdot 5 \text { to }-3.7)\end{array}$ & $\begin{array}{l}-0.8 \% \\
\text { (-3.7 to } 1.9)\end{array}$ & $\begin{array}{l}-3 \cdot 5 \% \\
(-4 \cdot 9 \text { to }-2 \cdot 3)\end{array}$ \\
\hline Macedonia & $\begin{array}{l}25 \cdot 1 \\
\text { (20.1 to 31.3) }\end{array}$ & $\begin{array}{c}17 \cdot 7 \\
(14 \cdot 7 \text { to } 21 \cdot 0)\end{array}$ & $\begin{array}{l}10 \cdot 5 \\
\text { (8.2 to } 13.3)\end{array}$ & $\begin{array}{r}9 \\
\text { (7 to 11) }\end{array}$ & $\begin{array}{r}4 \\
\text { (4 to } 5)^{2}\end{array}$ & (2 to 3$)^{2}$ & $\begin{array}{l}-2.7 \% \\
(-4.8 \text { to }-0.6)\end{array}$ & $\begin{array}{l}-5 \cdot 2 \% \\
(-7 \cdot 6 \text { to }-2 \cdot 4)\end{array}$ & $\begin{array}{l}-3 \cdot 8 \% \\
(-5 \cdot 3 \text { to }-2 \cdot 3)\end{array}$ \\
\hline Montenegro & $\begin{array}{l}15.9 \\
(10.4 \text { to } 23.0)\end{array}$ & $\begin{array}{l}18 \cdot 6 \\
(14 \cdot 0 \text { to } 24 \cdot 0)\end{array}$ & $\begin{array}{l}12 \cdot 3 \\
\text { (8.6 to } 17 \cdot 3)\end{array}$ & (1 to 2$)^{1}$ & $(1 \text { to } 2)^{1}$ & (1 to 1$)^{1}$ & $\begin{array}{l}1 \cdot 3 \% \\
(-2 \cdot 2 \text { to } 4 \cdot 7)\end{array}$ & $\begin{array}{l}-4 \cdot 2 \% \\
(-7 \cdot 8 \text { to }-0.2)\end{array}$ & $\begin{array}{l}-1 \cdot 1 \% \\
(-3 \cdot 3 \text { to } 1 \cdot 1)\end{array}$ \\
\hline Poland & $\begin{array}{l}34.0 \\
\text { (30.3 to 38.2) }\end{array}$ & $\begin{array}{c}8.6 \\
(7.4 \text { to } 9.9)\end{array}$ & $\begin{array}{c}4.8 \\
(3 \cdot 8 \text { to } 6 \cdot 1)\end{array}$ & $\begin{array}{c}179 \\
\text { (159 to 201) }\end{array}$ & $\begin{array}{c}33 \\
\text { (28 to } 37 \text { ) }\end{array}$ & $\begin{array}{c}20 \\
\text { (16 to } 26)\end{array}$ & $\begin{array}{l}-10 \cdot 6 \% \\
(-12 \cdot 0 \text { to }-9 \cdot 3)\end{array}$ & $\begin{array}{l}-5.8 \% \\
(-8.5 \text { to }-3.4)\end{array}$ & $\begin{array}{l}-8.5 \% \\
(-9.6 \text { to }-7.4)\end{array}$ \\
\hline Romania & $\begin{array}{l}152 \cdot 1 \\
(137 \cdot 4 \text { to } 169 \cdot 5)\end{array}$ & $\begin{array}{l}31 \cdot 6 \\
\text { (27.9 to } 35 \cdot 5)\end{array}$ & $\begin{array}{l}15.9 \\
(12 \cdot 2 \text { to } 19.9)\end{array}$ & $\begin{array}{c}414 \\
\text { (374 to } 462)\end{array}$ & $\begin{array}{c}73 \\
\text { (65 to } 82)\end{array}$ & $\begin{array}{c}37 \\
(28 \text { to } 46)\end{array}$ & $\begin{array}{l}-12 \cdot 1 \% \\
(-13 \cdot 3 \text { to }-10 \cdot 9)\end{array}$ & $\begin{array}{l}-6 \cdot 9 \% \\
(-9 \cdot 6 \text { to }-4 \cdot 3)\end{array}$ & $\begin{array}{l}-9.8 \% \\
(-11 \cdot 1 \text { to }-8 \cdot 7)\end{array}$ \\
\hline Serbia & $\begin{array}{l}15.8 \\
\text { (11.0 to 22.9) }\end{array}$ & $\begin{array}{c}12 \cdot 1 \\
\text { (10.1 to } 14 \cdot 2)\end{array}$ & $\begin{array}{l}10.6 \\
(8.5 \text { to } 13.0)\end{array}$ & $\begin{array}{c}22 \\
(15 \text { to } 32)\end{array}$ & $\begin{array}{c}13 \\
\text { (11 to } 16)\end{array}$ & $\begin{array}{r}10 \\
\text { (8 to } 12)\end{array}$ & $\begin{array}{l}-2.0 \% \\
\text { (-5.1 to } 1.0)\end{array}$ & $\begin{array}{l}-1 \cdot 3 \% \\
(-3 \cdot 8 \text { to } 1 \cdot 2)\end{array}$ & $\begin{array}{l}-1 \cdot 7 \% \\
(-3 \cdot 6 \text { to } 0.1)\end{array}$ \\
\hline Slovakia & $\begin{array}{l}15.9 \\
(12.7 \text { to } 19.5)\end{array}$ & $\begin{array}{c}9.5 \\
\text { (8.0 to 11.1) }\end{array}$ & $\begin{array}{c}6 \cdot 2 \\
(4.8 \text { to } 7 \cdot 9)\end{array}$ & $\begin{array}{c}12 \\
\text { (10 to } 15)\end{array}$ & $(4 \text { to } 6)^{5}$ & $\begin{array}{l}{ }^{4} \\
\text { (3 to } 5)^{-}\end{array}$ & $\begin{array}{l}-4 \cdot 0 \% \\
(-6 \cdot 1 \text { to }-2 \cdot 0)\end{array}$ & $\begin{array}{l}-4 \cdot 3 \% \\
(-7 \cdot 1 \text { to }-1 \cdot 6)\end{array}$ & $\begin{array}{l}-4 \cdot 1 \% \\
(-5 \cdot 5 \text { to }-2 \cdot 8)\end{array}$ \\
\hline Slovenia & $\begin{array}{l}12.9 \\
(10.6 \text { to } 15 \cdot 7)\end{array}$ & $\begin{array}{c}11.0 \\
\text { (8.8 to } 13.3)\end{array}$ & $\begin{array}{c}7 \cdot 4 \\
\text { (5.5 to } 9.8)\end{array}$ & $(2 \text { to } 3)^{3}$ & $(2 \text { to } 3)^{2}$ & (1 to 2$)^{2}$ & $\begin{array}{l}-1 \cdot 2 \% \\
(-3.2 \text { to } 0.8)\end{array}$ & $\begin{array}{l}-4 \cdot 1 \% \\
(-7 \cdot 3 \text { to }-0.8)\end{array}$ & $\begin{array}{l}-2.5 \% \\
(-3.9 \text { to }-1.0)\end{array}$ \\
\hline Eastern Europe & $\begin{array}{l}60 \cdot 1 \\
\text { (54.3 to } 65 \cdot 7)\end{array}$ & $\begin{array}{l}36 \cdot 3 \\
\text { (32.8 to } 40 \cdot 4)\end{array}$ & $\begin{array}{l}17 \cdot 6 \\
(14 \cdot 4 \text { to } 20 \cdot 6)\end{array}$ & $\begin{array}{c}1566 \\
\text { (1415 to } 1714)\end{array}$ & $\begin{array}{c}812 \\
\text { (733 to } 904)\end{array}$ & $\begin{array}{c}433 \\
\text { (354 to } 507 \text { ) }\end{array}$ & $\begin{array}{l}-3 \cdot 9 \% \\
(-4.9 \text { to }-2 \cdot 8)\end{array}$ & $\begin{array}{l}-7 \cdot 3 \% \\
(-9 \cdot 4 \text { to }-5 \cdot 4)\end{array}$ & $\begin{array}{l}-5 \cdot 3 \% \\
(-6 \cdot 1 \text { to }-4 \cdot 6)\end{array}$ \\
\hline Belarus & $\begin{array}{l}40.5 \\
\text { (35.1 to } 46 \cdot 3)\end{array}$ & $\begin{array}{l}25.0 \\
(20 \cdot 8 \text { to } 30.0)\end{array}$ & $\begin{array}{l}10 \cdot 6 \\
\text { (7.7 to } 13 \cdot 9)\end{array}$ & $\begin{array}{c}53 \\
\text { (46 to } 60)\end{array}$ & $\begin{array}{c}25 \\
\text { (20 to } 30 \text { ) }\end{array}$ & $\begin{array}{r}11 \\
\text { (8 to } 15)\end{array}$ & $\begin{array}{l}-3 \cdot 7 \% \\
(-5 \cdot 4 \text { to }-1 \cdot 9)\end{array}$ & $\begin{array}{l}-8.7 \% \\
(-11.9 \text { to }-5 \cdot 5)\end{array}$ & $\begin{array}{l}-5 \cdot 9 \% \\
(-7 \cdot 2 \text { to }-4 \cdot 5)\end{array}$ \\
\hline Estonia & $\begin{array}{l}45 \cdot 1 \\
(37 \cdot 4 \text { to } 54 \cdot 1)\end{array}$ & $\begin{array}{c}17 \cdot 7 \\
(14 \cdot 7 \text { to } 21 \cdot 5)\end{array}$ & $\begin{array}{c}7.1 \\
\text { (4.9 to } 9.5)\end{array}$ & $\begin{array}{r}8 \\
\text { (7 to } 10)\end{array}$ & $(2 \text { to } 3)^{3}$ & (1 to 1$)^{1}$ & $\begin{array}{l}-7 \cdot 2 \% \\
(-9 \cdot 2 \text { to }-5 \cdot 3)\end{array}$ & $\begin{array}{l}-9 \cdot 2 \% \\
(-12 \cdot 7 \text { to }-5 \cdot 8)\end{array}$ & $\begin{array}{l}-8 \cdot 1 \% \\
(-9.9 \text { to }-6.6)\end{array}$ \\
\hline Latvia & $\begin{array}{l}49 \cdot 7 \\
(42 \cdot 2 \text { to } 58 \cdot 1)\end{array}$ & $\begin{array}{l}20 \cdot 8 \\
\text { (17.1 to } 24 \cdot 5)\end{array}$ & $\begin{array}{c}8.5 \\
\text { (6.2 to } 11 \cdot 1)\end{array}$ & $\begin{array}{c}16 \\
\text { (13 to } 18)\end{array}$ & $(4 \text { to } 6)^{5}$ & (1 to 3$)^{2}$ & $\begin{array}{l}-6.7 \% \\
(-8.5 \text { to }-5.0)\end{array}$ & $\begin{array}{l}-9 \cdot 0 \% \\
(-12 \cdot 3 \text { to }-6 \cdot 3)\end{array}$ & $\begin{array}{l}-7.7 \% \\
(-9.2 \text { to }-6.4)\end{array}$ \\
\hline Lithuania & $\begin{array}{l}29.6 \\
\text { (24.9 to } 34.9)\end{array}$ & $\begin{array}{l}13 \cdot 7 \\
(11 \cdot 5 \text { to } 16 \cdot 3)\end{array}$ & $\begin{array}{c}6 \cdot 1 \\
(4 \cdot 6 \text { to } 7 \cdot 8)\end{array}$ & $\begin{array}{c}15 \\
\text { (13 to } 18)\end{array}$ & $(4 \text { to } 5)^{5}$ & (2 to 3) & $\begin{array}{l}-5.9 \% \\
(-7 \cdot 7 \text { to }-4 \cdot 0)\end{array}$ & $\begin{array}{l}-8 \cdot 2 \% \\
(-11 \cdot 1 \text { to }-5 \cdot 2)\end{array}$ & $\begin{array}{l}-6 \cdot 9 \% \\
(-8 \cdot 3 \text { to }-5 \cdot 6)\end{array}$ \\
\hline Moldova & $\begin{array}{l}68.9 \\
\text { (59.7 to } 79.6)\end{array}$ & $\begin{array}{l}34 \cdot 7 \\
(28 \cdot 5 \text { to } 41 \cdot 3)\end{array}$ & $\begin{array}{l}21.8 \\
(16 \cdot 0 \text { to } 28 \cdot 2)\end{array}$ & $\begin{array}{c}50 \\
\text { (43 to } 57 \text { ) }\end{array}$ & $\begin{array}{c}16 \\
\text { (13 to } 19)\end{array}$ & $\begin{array}{r}9 \\
\text { (7 to 12) }\end{array}$ & $\begin{array}{l}-5 \cdot 3 \% \\
(-7 \cdot 2 \text { to }-3 \cdot 4)\end{array}$ & $\begin{array}{l}-4 \cdot 7 \% \\
(-7 \cdot 7 \text { to }-1 \cdot 8)\end{array}$ & $\begin{array}{l}-5 \cdot 0 \% \\
(-6.6 \text { to }-3 \cdot 7)\end{array}$ \\
\hline Russia & $\begin{array}{l}64.9 \\
\text { (57.7 to } 72.6)\end{array}$ & $\begin{array}{l}36.9 \\
(32.5 \text { to } 42.0)\end{array}$ & $\begin{array}{l}16 \cdot 8 \\
(13 \cdot 5 \text { to } 20 \cdot 2)\end{array}$ & $\begin{array}{c}1099 \\
\text { (976 to 1229) }\end{array}$ & $\begin{array}{c}575 \\
\text { (507 to 655) }\end{array}$ & $\begin{array}{c}291 \\
\text { (234 to 351) }\end{array}$ & $\begin{array}{l}-4 \cdot 4 \% \\
(-5 \cdot 7 \text { to }-2 \cdot 9)\end{array}$ & $\begin{array}{l}-7 \cdot 9 \% \\
(-10 \cdot 5 \text { to }-5 \cdot 6)\end{array}$ & $\begin{array}{l}-5.9 \% \\
(-6.8 \text { to }-5.0)\end{array}$ \\
\hline Ukraine & $\begin{array}{l}53 \cdot 3 \\
(46 \cdot 3 \text { to } 60.8)\end{array}$ & $\begin{array}{l}39 \cdot 6 \\
(34 \cdot 5 \text { to } 45 \cdot 4)\end{array}$ & $\begin{array}{l}23 \cdot 1 \\
\text { (17.5 to } 29 \cdot 2)\end{array}$ & $\begin{array}{c}326 \\
\text { (283 to } 372 \text { ) }\end{array}$ & $\begin{array}{c}184 \\
\text { (161 to } 211)\end{array}$ & $\begin{array}{c}116 \\
\text { (88 to } 147 \text { ) }\end{array}$ & $\begin{array}{l}-2.3 \% \\
(-3.7 \text { to }-0.8)\end{array}$ & $\begin{array}{l}-5 \cdot 4 \% \\
(-8 \cdot 4 \text { to }-2 \cdot 7)\end{array}$ & $\begin{array}{l}-3.7 \% \\
(-4.9 \text { to }-2 \cdot 5)\end{array}$ \\
\hline Western Europe & $\begin{array}{l}12 \cdot 7 \\
(11.7 \text { to } 13.8)\end{array}$ & $\begin{array}{c}8.1 \\
(7.3 \text { to } 8.6)\end{array}$ & $\begin{array}{c}6 \cdot 3 \\
(5 \cdot 3 \text { to } 7 \cdot 1)\end{array}$ & $\begin{array}{c}565 \\
\text { (522 to } 615)\end{array}$ & $\begin{array}{c}365 \\
\text { (330 to } 390)\end{array}$ & $\begin{array}{c}288 \\
\text { (243 to } 326)\end{array}$ & $\begin{array}{l}-3 \cdot 5 \% \\
(-4 \cdot 2 \text { to }-2 \cdot 9)\end{array}$ & $\begin{array}{l}-2 \cdot 5 \% \\
(-3.8 \text { to }-1 \cdot 4)\end{array}$ & $\begin{array}{l}-3 \cdot 1 \% \\
(-3.8 \text { to }-2 \cdot 5)\end{array}$ \\
\hline
\end{tabular}




\begin{tabular}{|c|c|c|c|c|c|c|c|c|c|}
\hline & \multicolumn{3}{|c|}{ Maternal mortality ratio (per 100000 livebirths) } & \multicolumn{3}{|c|}{ Number of maternal deaths } & \multicolumn{3}{|c|}{$\begin{array}{l}\text { Annualised rate of change in maternal } \\
\text { mortality ratio }(\%)\end{array}$} \\
\hline & 1990 & 2003 & 2013 & 1990 & 2003 & 2013 & $1990-2003$ & 2003-13 & $1990-2013$ \\
\hline \multicolumn{10}{|c|}{ (Continued from previous page) } \\
\hline Andorra & $\begin{array}{c}5.5 \\
(3.1 \text { to } 9.0)\end{array}$ & $\begin{array}{c}3.1 \\
\text { (1.9 to } 4.9)\end{array}$ & $\begin{array}{c}3.0 \\
\text { (1.6 to } 4.8)\end{array}$ & $\begin{array}{r}0 \\
(0 \text { to } 0)\end{array}$ & $\begin{array}{r}0 \\
(0 \text { to } 0)\end{array}$ & $\begin{array}{r}0 \\
(0 \text { to } 0)\end{array}$ & $\begin{array}{l}-4 \cdot 4 \% \\
(-9 \cdot 2 \text { to } 0 \cdot 1)\end{array}$ & $\begin{array}{l}-0 \cdot 6 \% \\
(-6 \cdot 3 \text { to } 5 \cdot 6)\end{array}$ & $\begin{array}{l}-2.7 \% \\
(-5 \cdot 9 \text { to } 0.2)\end{array}$ \\
\hline Austria & $\begin{array}{l}10 \cdot 3 \\
(8 \cdot 5 \text { to } 12 \cdot 2)\end{array}$ & $\begin{array}{c}5 \cdot 0 \\
(4 \cdot 0 \text { to } 6 \cdot 0)\end{array}$ & $\begin{array}{c}3 \cdot 2 \\
(2 \cdot 3 \text { to } 4 \cdot 0)\end{array}$ & $\begin{array}{r}9 \\
\text { (8 to } 11)\end{array}$ & $\begin{array}{l}{ }^{4} \\
\text { (3 to } 5)\end{array}$ & $(2 \text { to } 3)^{3}$ & $\begin{array}{l}-5 \cdot 6 \% \\
(-7 \cdot 5 \text { to }-3 \cdot 6)\end{array}$ & $\begin{array}{l}-4 \cdot 5 \% \\
(-7 \cdot 4 \text { to }-1 \cdot 8)\end{array}$ & $\begin{array}{l}-5 \cdot 1 \% \\
(-6 \cdot 5 \text { to }-3 \cdot 8)\end{array}$ \\
\hline Belgium & $\begin{array}{l}11 \cdot 3 \\
(9 \cdot 4 \text { to } 13 \cdot 3)\end{array}$ & $\begin{array}{l}8.4 \\
\text { (6.9 to } 10 \cdot 1)\end{array}$ & $\begin{array}{c}6.7 \\
(5 \cdot 0 \text { to } 8.6)\end{array}$ & $\begin{array}{c}14 \\
\text { (12 to } 16)\end{array}$ & $\begin{array}{r}10 \\
(8 \text { to } 12)\end{array}$ & $\begin{array}{r}9 \\
\text { (7 to } 11)\end{array}$ & $\begin{array}{l}-2 \cdot 2 \% \\
(-4 \cdot 0 \text { to }-0.5)\end{array}$ & $\begin{array}{l}-2 \cdot 3 \% \\
(-5 \cdot 2 \text { to } 0.5)\end{array}$ & $\begin{array}{l}-2 \cdot 3 \% \\
(-3 \cdot 6 \text { to }-1 \cdot 0)\end{array}$ \\
\hline Cyprus & $\begin{array}{l}13 \cdot 3 \\
(9 \cdot 6 \text { to } 17 \cdot 7)\end{array}$ & $\begin{array}{c}8.7 \\
\text { (6.7 to } 11.0)\end{array}$ & $\begin{array}{c}6.1 \\
(4 \cdot 4 \text { to } 8 \cdot 1)\end{array}$ & $(1 \text { to } 3)^{2}$ & (1 to 1$)^{1}$ & (1 to 1$)^{1}$ & $\begin{array}{l}-3 \cdot 2 \% \\
(-6 \cdot 0 \text { to }-0.4)\end{array}$ & $\begin{array}{l}-3 \cdot 6 \% \\
(-7 \cdot 4 \text { to } 0.1)\end{array}$ & $\begin{array}{l}-3 \cdot 4 \% \\
(-5 \cdot 2 \text { to }-1 \cdot 6)\end{array}$ \\
\hline Denmark & $\begin{array}{c}7 \cdot 4 \\
(6 \cdot 2 \text { to } 9 \cdot 1)\end{array}$ & $\begin{array}{c}5 \cdot 8 \\
(4 \cdot 7 \text { to } 7 \cdot 1)\end{array}$ & $\begin{array}{c}4 \cdot 8 \\
(3 \cdot 4 \text { to } 6 \cdot 2)\end{array}$ & $(4 \text { to } 6)^{5}$ & $\begin{array}{l}{ }^{4} \\
\text { (3 to } 5)\end{array}$ & $(2 \text { to } 4)^{3}$ & $\begin{array}{l}-1 \cdot 9 \% \\
(-4 \cdot 4 \text { to } 0 \cdot 1)\end{array}$ & $\begin{array}{l}-2 \cdot 1 \% \\
(-5 \cdot 0 \text { to } 0.7)\end{array}$ & $\begin{array}{l}-2.0 \% \\
(-3.7 \text { to }-0.5)\end{array}$ \\
\hline Finland & $\begin{array}{c}7 \cdot 2 \\
(5.9 \text { to } 8.8)\end{array}$ & $\begin{array}{c}6 \cdot 4 \\
(5 \cdot 3 \text { to } 7 \cdot 6)\end{array}$ & $\begin{array}{c}3.9 \\
(3.0 \text { to } 5.0)\end{array}$ & $(4 \text { to } 6)^{5}$ & $\begin{array}{r}4 \\
\text { (3 to } 4)\end{array}$ & $(2 \text { to } 3)^{2}$ & $\begin{array}{l}-0.9 \% \\
(-2.8 \text { to } 1.0)\end{array}$ & $\begin{array}{l}-5 \cdot 0 \% \\
(-7 \cdot 6 \text { to }-2 \cdot 3)\end{array}$ & $\begin{array}{l}-2 \cdot 7 \% \\
(-4 \cdot 1 \text { to }-1 \cdot 4)\end{array}$ \\
\hline France & $\begin{array}{l}15 \cdot 6 \\
\text { (13.5 to } 17 \cdot 7)\end{array}$ & $\begin{array}{c}11 \cdot 0 \\
(9 \cdot 3 \text { to } 12 \cdot 6)\end{array}$ & $\begin{array}{c}8.8 \\
\text { (6.9 to } 11.0)\end{array}$ & $\begin{array}{c}116 \\
\text { (100 to } 132)\end{array}$ & $\begin{array}{c}87 \\
\text { (74 to } 100)\end{array}$ & $\begin{array}{c}70 \\
\text { (55 to } 88)\end{array}$ & $\begin{array}{l}-2 \cdot 7 \% \\
(-4 \cdot 1 \text { to }-1 \cdot 2)\end{array}$ & $\begin{array}{l}-2.2 \% \\
(-4.5 \text { to } 0.2)\end{array}$ & $\begin{array}{l}-2 \cdot 5 \% \\
(-3 \cdot 7 \text { to }-1 \cdot 3)\end{array}$ \\
\hline Germany & $\begin{array}{l}18.0 \\
\text { (15.9 to 20.4) }\end{array}$ & $\begin{array}{c}8.3 \\
\text { (7.1 to } 9.6)\end{array}$ & $\begin{array}{c}6.5 \\
(5.0 \text { to } 7.9)\end{array}$ & $\begin{array}{c}146 \\
(129 \text { to } 165)\end{array}$ & $\begin{array}{c}62 \\
\text { (52 to } 71 \text { ) }\end{array}$ & $\begin{array}{c}46 \\
\text { (36 to } 56)\end{array}$ & $\begin{array}{l}-5.9 \% \\
(-7 \cdot 4 \text { to }-4 \cdot 7)\end{array}$ & $\begin{array}{l}-2.5 \% \\
(-4.6 \text { to }-0.5)\end{array}$ & $\begin{array}{l}-4 \cdot 4 \% \\
(-5 \cdot 6 \text { to }-3 \cdot 4)\end{array}$ \\
\hline Greece & $\begin{array}{c}9.5 \\
\text { (8.0 to 11.1) }\end{array}$ & $\begin{array}{c}7.9 \\
\text { (6.6 to 9.3) }\end{array}$ & $\begin{array}{c}9 \cdot 1 \\
(7 \cdot 2 \text { to } 11 \cdot 3)\end{array}$ & $\begin{array}{r}10 \\
\text { (8 to } 11)\end{array}$ & $\begin{array}{r}9 \\
\text { (7 to } 11)\end{array}$ & $\begin{array}{r}10 \\
\text { (8 to } 12 \text { ) }\end{array}$ & $\begin{array}{l}-1 \cdot 4 \% \\
(-3.2 \text { to } 0.2)\end{array}$ & $\begin{array}{l}1.4 \% \\
(-1.0 \text { to } 4.0)\end{array}$ & $\begin{array}{l}-0.2 \% \\
(-1 \cdot 3 \text { to } 1.0)\end{array}$ \\
\hline Iceland & $\begin{array}{c}7 \cdot 1 \\
\text { (5.5 to } 9.0)\end{array}$ & $\begin{array}{c}4.2 \\
(3.0 \text { to } 5.6)\end{array}$ & $\begin{array}{c}2.4 \\
(1.6 \text { to } 3.6)\end{array}$ & $\begin{array}{r}0 \\
(0 \text { to } 0)^{0}\end{array}$ & $\begin{array}{r}0 \\
(0 \text { to } 0)^{0}\end{array}$ & $\begin{array}{r}0 \\
(0 \text { to } 0)^{0}\end{array}$ & $\begin{array}{l}-4 \cdot 1 \% \\
(-7 \cdot 1 \text { to }-1 \cdot 1)\end{array}$ & $\begin{array}{l}-5 \cdot 4 \% \\
(-9 \cdot 9 \text { to }-1 \cdot 0)\end{array}$ & $\begin{array}{l}-4.7 \% \\
(-6.9 \text { to }-2 \cdot 6)\end{array}$ \\
\hline Ireland & $\begin{array}{c}6 \cdot 3 \\
(5 \cdot 2 \text { to } 7 \cdot 6)\end{array}$ & $\begin{array}{c}3.9 \\
\text { (3.1 to } 4.7 \text { ) }\end{array}$ & $\begin{array}{c}3 \cdot 3 \\
(2 \cdot 3 \text { to } 4 \cdot 4)\end{array}$ & (3 to 4$)^{3}$ & (2 to 3$)^{2}$ & (2 to 3$)^{2}$ & $\begin{array}{l}-3.7 \% \\
(-5.6 \text { to }-1.9)\end{array}$ & $\begin{array}{l}-1.7 \% \\
(-5.0 \text { to } 1.7)\end{array}$ & $\begin{array}{l}-2 \cdot 8 \% \\
(-4 \cdot 4 \text { to }-1 \cdot 3)\end{array}$ \\
\hline Israel & $\begin{array}{l}10 \cdot 4 \\
(8.8 \text { to } 12.5)\end{array}$ & $\begin{array}{c}7.1 \\
\text { (5.9 to 8.5) }\end{array}$ & $\begin{array}{c}4 \cdot 4 \\
(3.2 \text { to } 5.5)\end{array}$ & $\begin{array}{r}10 \\
\text { (9 to } 12 \text { ) }\end{array}$ & $\begin{array}{r}10 \\
\text { (8 to } 12)\end{array}$ & $\begin{array}{r}{ }^{7} \\
\text { (5 to } 9)^{-}\end{array}$ & $\begin{array}{l}-2 \cdot 9 \% \\
(-4 \cdot 8 \text { to }-1 \cdot 1)\end{array}$ & $\begin{array}{l}-4 \cdot 9 \% \\
(-8 \cdot 2 \text { to }-2 \cdot 2)\end{array}$ & $\begin{array}{l}-3.8 \% \\
(-5.4 \text { to }-2 \cdot 4)\end{array}$ \\
\hline Italy & $\begin{array}{c}9.9 \\
(8.6 \text { to } 11.4)\end{array}$ & $\begin{array}{c}5.7 \\
(4.7 \text { to } 6.7)\end{array}$ & $\begin{array}{c}4 \cdot 3 \\
(3 \cdot 2 \text { to } 5 \cdot 5)\end{array}$ & $\begin{array}{c}54 \\
\text { (47 to } 63 \text { ) }\end{array}$ & $\begin{array}{c}32 \\
\text { (27 to 38) }\end{array}$ & $\begin{array}{c}24 \\
\text { (18 to } 32)\end{array}$ & $\begin{array}{l}-4 \cdot 3 \% \\
(-5 \cdot 8 \text { to }-2 \cdot 7)\end{array}$ & $\begin{array}{l}-2.8 \% \\
(-5.7 \text { to }-0.2)\end{array}$ & $\begin{array}{l}-3.7 \% \\
(-5.0 \text { to }-2 \cdot 4)\end{array}$ \\
\hline Luxembourg & $\begin{array}{c}5 \cdot 0 \\
(4 \cdot 1 \text { to } 6 \cdot 1)\end{array}$ & $\begin{array}{c}7.0 \\
\text { (5.4 to } 8.6)\end{array}$ & $\begin{array}{c}6 \cdot 1 \\
(4.5 \text { to } 8.0)\end{array}$ & $\begin{array}{r}0 \\
(0 \text { to } 0)^{0}\end{array}$ & $\begin{array}{r}0 \\
(0 \text { to } 0)\end{array}$ & (0 to 1$)^{0}$ & $\begin{array}{l}2 \cdot 6 \% \\
\text { (0.3 to } 4 \cdot 6)\end{array}$ & $\begin{array}{l}-1 \cdot 5 \% \\
\text { (-4.7 to 2.0) }\end{array}$ & $\begin{array}{l}0.8 \% \\
(-0.8 \text { to } 2.4)\end{array}$ \\
\hline Malta & $\begin{array}{c}6.9 \\
(5 \cdot 5 \text { to } 8 \cdot 4)\end{array}$ & $\begin{array}{c}5 \cdot 4 \\
(4 \cdot 2 \text { to } 6.9)\end{array}$ & $\begin{array}{c}2.9 \\
\text { (2.0 to 3.9) }\end{array}$ & $\begin{array}{l}0 \\
(0 \text { to } 1)\end{array}$ & $\begin{array}{r}0 \\
(0 \text { to } 0)\end{array}$ & $\begin{array}{r}0 \\
(0 \text { to } 0)\end{array}$ & $\begin{array}{l}-1.8 \% \\
(-4.3 \text { to } 0.5)\end{array}$ & $\begin{array}{l}-6 \cdot 5 \% \\
(-10 \cdot 4 \text { to }-2 \cdot 8)\end{array}$ & $\begin{array}{l}-3.8 \% \\
(-5.6 \text { to }-2 \cdot 1)\end{array}$ \\
\hline Netherlands & $\begin{array}{l}11.7 \\
\text { (9.8 to } 13.9)\end{array}$ & $\begin{array}{c}10.8 \\
\text { (8.9 to } 12.7)\end{array}$ & $\begin{array}{c}6.7 \\
\text { (5.1 to 8.3) }\end{array}$ & $\begin{array}{c}23 \\
\text { (19 to 27) }\end{array}$ & $\begin{array}{c}22 \\
\text { (18 to } 25)\end{array}$ & $\begin{array}{r}12 \\
(9 \text { to } 15)\end{array}$ & $\begin{array}{l}-0.6 \% \\
(-2.3 \text { to } 1.0)\end{array}$ & $\begin{array}{l}-4 \cdot 8 \% \\
(-7 \cdot 4 \text { to }-2 \cdot 1)\end{array}$ & $\begin{array}{l}-2 \cdot 5 \% \\
(-3 \cdot 7 \text { to }-1 \cdot 3)\end{array}$ \\
\hline Norway & $\begin{array}{c}5.9 \\
(4.9 \text { to } 7.1)\end{array}$ & $\begin{array}{c}6 \cdot 3 \\
(5 \cdot 1 \text { to } 7 \cdot 7)\end{array}$ & $\begin{array}{c}4.5 \\
\text { (3.5 to } 5.6)\end{array}$ & $\begin{array}{r}4 \\
\text { (3 to } 4)\end{array}$ & $\begin{array}{l}{ }^{4} \\
\text { (3 to } 5)^{-1}\end{array}$ & $(2 \text { to } 4)^{3}$ & $\begin{array}{l}0.5 \% \\
\text { (-1.4 to } 2.5)\end{array}$ & $\begin{array}{l}-3.4 \% \\
(-6.0 \text { to }-0.7)\end{array}$ & $\begin{array}{l}-1 \cdot 2 \% \\
(-2 \cdot 4 \text { to } 0 \cdot 1)\end{array}$ \\
\hline Portugal & $\begin{array}{l}20 \cdot 6 \\
\text { (17.7 to 24.1) }\end{array}$ & $\begin{array}{l}13.6 \\
\text { (11.5 to } 16.0)\end{array}$ & $\begin{array}{c}9.8 \\
(7 \cdot 7 \text { to } 12 \cdot 2)\end{array}$ & $\begin{array}{c}23 \\
\text { (20 to } 27)\end{array}$ & $\begin{array}{c}15 \\
\text { (13 to } 17)\end{array}$ & $\begin{array}{r}9 \\
\text { (7 to 11) }\end{array}$ & $\begin{array}{l}-3 \cdot 2 \% \\
(-4 \cdot 9 \text { to }-1 \cdot 5)\end{array}$ & $\begin{array}{l}-3.3 \% \\
(-6.0 \text { to }-0.8)\end{array}$ & $\begin{array}{l}-3 \cdot 3 \% \\
(-4 \cdot 4 \text { to }-2 \cdot 1)\end{array}$ \\
\hline Spain & $\begin{array}{l}12 \cdot 3 \\
\text { (10.7 to } 14 \cdot 3)\end{array}$ & $\begin{array}{c}7.0 \\
(6.0 \text { to } 8.2)\end{array}$ & $\begin{array}{c}6 \cdot 2 \\
(4 \cdot 8 \text { to } 7 \cdot 6)\end{array}$ & $\begin{array}{c}47 \\
\text { (41 to } 54)\end{array}$ & $\begin{array}{c}32 \\
\text { (28 to 37) }\end{array}$ & $\begin{array}{c}31 \\
\text { (24 to } 38)\end{array}$ & $\begin{array}{l}-4 \cdot 3 \% \\
(-5 \cdot 8 \text { to }-2 \cdot 8)\end{array}$ & $\begin{array}{l}-1 \cdot 4 \% \\
(-3.8 \text { to } 1.2)\end{array}$ & $\begin{array}{l}-3 \cdot 0 \% \\
(-4 \cdot 2 \text { to }-1 \cdot 9)\end{array}$ \\
\hline Sweden & $\begin{array}{c}7.0 \\
\text { (5.7 to 8.6) }\end{array}$ & $\begin{array}{c}4.9 \\
\text { (3.9 to 5.9) }\end{array}$ & $\begin{array}{c}3 \cdot 7 \\
(2 \cdot 7 \text { to } 4.8)\end{array}$ & $\begin{array}{r}8 \\
\text { (7 to } 10)\end{array}$ & $(4 \text { to } 6)^{5}$ & (3 to 6$)^{4}$ & $\begin{array}{l}-2.7 \% \\
(-4.9 \text { to }-0.7)\end{array}$ & $\begin{array}{l}-2.8 \% \\
(-6.1 \text { to } 0.1)\end{array}$ & $\begin{array}{l}-2 \cdot 7 \% \\
(-4 \cdot 5 \text { to }-1 \cdot 3)\end{array}$ \\
\hline Switzerland & $\begin{array}{c}6 \cdot 7 \\
\text { (5.5 to } 8.3)\end{array}$ & $\begin{array}{c}5 \cdot 8 \\
\text { (4.6 to } 7 \cdot 2)\end{array}$ & $\begin{array}{c}3.9 \\
(2.9 \text { to } 5.1)\end{array}$ & (4 to 7$)^{5}$ & $\begin{array}{l}{ }^{4} \\
\text { (3 to } 5)^{-}\end{array}$ & $(2 \text { to } 4)^{3}$ & $\begin{array}{l}-1.1 \% \\
(-3 \cdot 4 \text { to } 1.1)\end{array}$ & $\begin{array}{l}-4.0 \% \\
(-7.0 \text { to }-1 \cdot 0)\end{array}$ & $\begin{array}{l}-2.3 \% \\
(-4.1 \text { to }-0.9)\end{array}$ \\
\hline UK & $\begin{array}{l}10 \cdot 4 \\
(9 \cdot 4 \text { to } 11 \cdot 1)\end{array}$ & $\begin{array}{c}7 \cdot 7 \\
\text { (7.0 to } 8 \cdot 3)\end{array}$ & $\begin{array}{c}6 \cdot 1 \\
(5 \cdot 2 \text { to } 6 \cdot 9)\end{array}$ & $\begin{array}{c}80 \\
\text { (73 to } 86 \text { ) }\end{array}$ & $\begin{array}{c}57 \\
\text { (52 to } 62 \text { ) }\end{array}$ & $\begin{array}{c}47 \\
\text { (40 to } 54)\end{array}$ & $\begin{array}{l}-2 \cdot 3 \% \\
(-2 \cdot 9 \text { to }-1 \cdot 7)\end{array}$ & $\begin{array}{l}-2 \cdot 4 \% \\
(-3 \cdot 8 \text { to }-1 \cdot 0)\end{array}$ & $\begin{array}{l}-2 \cdot 3 \% \\
(-3 \cdot 0 \text { to }-1 \cdot 7)\end{array}$ \\
\hline $\begin{array}{l}\text { Andean } \\
\text { Latin America }\end{array}$ & $\begin{array}{l}187.9 \\
(169.5 \text { to } 208 \cdot 7)\end{array}$ & $\begin{array}{l}112 \cdot 5 \\
\text { (99.7 to } 125 \cdot 1)\end{array}$ & $\begin{array}{l}96 \cdot 0 \\
\text { (75.3 to } 117 \cdot 2)\end{array}$ & $\begin{array}{c}2249 \\
\text { (2028 to 2497) }\end{array}$ & $\begin{array}{c}1366 \\
\text { (1211 to } 1520)\end{array}$ & $\begin{array}{c}1164 \\
\text { (912 to } 1421)\end{array}$ & $\begin{array}{l}-4 \cdot 0 \% \\
(-5 \cdot 2 \text { to }-2 \cdot 8)\end{array}$ & $\begin{array}{l}-1.6 \% \\
(-4.0 \text { to } 0.6)\end{array}$ & $\begin{array}{l}-2 \cdot 9 \% \\
(-4 \cdot 1 \text { to }-2 \cdot 0)\end{array}$ \\
\hline Bolivia & $\begin{array}{l}382 \cdot 4 \\
\text { (312.1 to } 458 \cdot 1)\end{array}$ & $\begin{array}{l}229.9 \\
\text { (178.7 to 281.9) }\end{array}$ & $\begin{array}{l}179 \cdot 6 \\
\text { (110.4 to 257.2) }\end{array}$ & $\begin{array}{c}977 \\
\text { (798 to 1171) }\end{array}$ & $\begin{array}{c}616 \\
\text { (479 to } 755)\end{array}$ & $\begin{array}{c}499 \\
\text { (307 to } 715 \text { ) }\end{array}$ & $\begin{array}{l}-3 \cdot 9 \% \\
(-6 \cdot 3 \text { to }-1 \cdot 7)\end{array}$ & $\begin{array}{l}-2.6 \% \\
(-6.9 \text { to } 1 \cdot 3)\end{array}$ & $\begin{array}{l}-3.4 \% \\
(-5.6 \text { to }-1 \cdot 5)\end{array}$ \\
\hline Ecuador & $\begin{array}{l}142 \cdot 7 \\
\text { (128.4 to } 159 \cdot 9)\end{array}$ & $\begin{array}{l}86 \cdot 0 \\
\text { (72.8 to } 100 \cdot 3)\end{array}$ & $\begin{array}{l}84.6 \\
(57.7 \text { to } 122.0)\end{array}$ & $\begin{array}{c}430 \\
\text { (386 to } 481 \text { ) }\end{array}$ & $\begin{array}{c}282 \\
\text { (239 to } 329)\end{array}$ & $\begin{array}{c}282 \\
\text { (192 to } 406)\end{array}$ & $\begin{array}{l}-3 \cdot 9 \% \\
(-5 \cdot 4 \text { to }-2 \cdot 4)\end{array}$ & $\begin{array}{l}-0.3 \% \\
(-4.6 \text { to } 3.7)\end{array}$ & $\begin{array}{l}-2 \cdot 3 \% \\
(-4 \cdot 1 \text { to }-0.7)\end{array}$ \\
\hline Peru & $\begin{array}{l}131 \cdot 5 \\
\text { (114.1 to } 152 \cdot 6)\end{array}$ & $\begin{array}{l}75 \cdot 7 \\
(64 \cdot 6 \text { to } 88 \cdot 4)\end{array}$ & $\begin{array}{l}63 \cdot 7 \\
\text { (45.6 to } 85 \cdot 4)\end{array}$ & $\begin{array}{c}842 \\
\text { (731 to } 977)\end{array}$ & $\begin{array}{c}468 \\
\text { (400 to 547) }\end{array}$ & $\begin{array}{c}383 \\
\text { (274 to } 513)\end{array}$ & $\begin{array}{l}-4 \cdot 3 \% \\
(-5 \cdot 9 \text { to }-2 \cdot 6)\end{array}$ & $\begin{array}{l}-1.8 \% \\
(-5 \cdot 2 \text { to } 1.6)\end{array}$ & $\begin{array}{l}-3 \cdot 2 \% \\
(-4 \cdot 8 \text { to }-1 \cdot 7)\end{array}$ \\
\hline $\begin{array}{l}\text { Central } \\
\text { Latin America }\end{array}$ & $\begin{array}{l}78 \cdot 8 \\
\text { (74.9 to } 82 \cdot 3)\end{array}$ & $\begin{array}{l}67.9 \\
\text { (63.7 to } 72.6)\end{array}$ & $\begin{array}{l}59 \cdot 9 \\
(53 \cdot 8 \text { to } 66 \cdot 7)\end{array}$ & $\begin{array}{c}3884 \\
\text { (3690 to 4056) }\end{array}$ & $\begin{array}{c}3446 \\
\text { (3231 to 3683) }\end{array}$ & $\begin{array}{c}2950 \\
\text { (2649 to } 3283)\end{array}$ & $\begin{array}{l}-1 \cdot 1 \% \\
(-1 \cdot 6 \text { to }-0.7)\end{array}$ & $\begin{array}{l}-1 \cdot 3 \% \\
(-2 \cdot 2 \text { to }-0 \cdot 2)\end{array}$ & $\begin{array}{l}-1 \cdot 2 \% \\
(-1.6 \text { to }-0.7)\end{array}$ \\
\hline Colombia & $\begin{array}{l}68 \cdot 2 \\
\text { (60.7 to } 76 \cdot 7)\end{array}$ & $\begin{array}{l}77 \cdot 1 \\
\text { (67.2 to } 87.7)\end{array}$ & $\begin{array}{l}62 \cdot 9 \\
\text { (44.1 to 85.2) }\end{array}$ & $\begin{array}{c}633 \\
\text { (563 to } 712 \text { ) }\end{array}$ & $\begin{array}{c}725 \\
\text { (632 to 824) }\end{array}$ & $\begin{array}{c}577 \\
\text { (405 to } 782 \text { ) }\end{array}$ & $\begin{array}{l}0.9 \% \\
(-0.3 \text { to } 2 \cdot 2)\end{array}$ & $\begin{array}{l}-2 \cdot 2 \% \\
(-5 \cdot 6 \text { to } 1 \cdot 2)\end{array}$ & $\begin{array}{l}-0.4 \% \\
(-1.9 \text { to } 1.0)\end{array}$ \\
\hline & & & & & & & & (Table 1 continue & es on next page) \\
\hline
\end{tabular}




\begin{tabular}{|c|c|c|c|c|c|c|c|c|c|}
\hline & \multicolumn{3}{|c|}{ Maternal mortality ratio (per 100000 livebirths) } & \multicolumn{3}{|c|}{ Number of maternal deaths } & \multicolumn{3}{|c|}{$\begin{array}{l}\text { Annualised rate of change in maternal } \\
\text { mortality ratio }(\%)\end{array}$} \\
\hline & 1990 & 2003 & 2013 & 1990 & 2003 & 2013 & $1990-2003$ & $2003-13$ & 1990-2013 \\
\hline \multicolumn{10}{|c|}{ (Continued from previous page) } \\
\hline Costa Rica & $\begin{array}{l}31 \cdot 1 \\
(26 \cdot 9 \text { to } 36 \cdot 0)\end{array}$ & $\begin{array}{l}36 \cdot 3 \\
(31 \cdot 7 \text { to } 41 \cdot 5)\end{array}$ & $\begin{array}{l}24 \cdot 9 \\
(20 \cdot 1 \text { to } 30 \cdot 3)\end{array}$ & $\begin{array}{c}25 \\
\text { (22 to } 29)\end{array}$ & $\begin{array}{c}28 \\
(24 \text { to } 31)\end{array}$ & $\begin{array}{c}19 \\
\text { (15 to } 23)\end{array}$ & $\begin{array}{l}1.2 \% \\
(-0.3 \text { to } 2 \cdot 7)\end{array}$ & $\begin{array}{l}-3 \cdot 8 \% \\
(-6 \cdot 0 \text { to }-1 \cdot 5)\end{array}$ & $\begin{array}{l}-1.0 \% \\
(-2.0 \text { to } 0.1)\end{array}$ \\
\hline El Salvador & $\begin{array}{l}105 \cdot 5 \\
(90 \cdot 2 \text { to } 120 \cdot 4)\end{array}$ & $\begin{array}{l}57 \cdot 5 \\
(49 \cdot 2 \text { to } 66 \cdot 5)\end{array}$ & $\begin{array}{l}65 \cdot 8 \\
\text { (44.3 to } 91 \cdot 6)\end{array}$ & $\begin{array}{c}181 \\
\text { (155 to } 206)\end{array}$ & $\begin{array}{c}77 \\
\text { (66 to } 89)\end{array}$ & $\begin{array}{c}86 \\
\text { (58 to } 119)\end{array}$ & $\begin{array}{l}-4 \cdot 7 \% \\
(-6 \cdot 3 \text { to }-3 \cdot 1)\end{array}$ & $\begin{array}{l}1.2 \% \\
(-2 \cdot 6 \text { to } 4.9)\end{array}$ & $\begin{array}{l}-2 \cdot 1 \% \\
(-3 \cdot 8 \text { to }-0 \cdot 4)\end{array}$ \\
\hline Guatemala & $\begin{array}{l}112 \cdot 8 \\
(101 \cdot 0 \text { to } 126 \cdot 2)\end{array}$ & $\begin{array}{l}91 \cdot 8 \\
(81 \cdot 2 \text { to } 104 \cdot 2)\end{array}$ & $\begin{array}{l}86 \cdot 7 \\
(65 \cdot 8 \text { to } 110 \cdot 8)\end{array}$ & $\begin{array}{c}409 \\
\text { (367 to } 458)\end{array}$ & $\begin{array}{c}400 \\
\text { (353 to } 454)\end{array}$ & $\begin{array}{c}423 \\
\text { (321 to } 541)\end{array}$ & $\begin{array}{l}-1 \cdot 6 \% \\
(-2 \cdot 8 \text { to }-0 \cdot 4)\end{array}$ & $\begin{array}{l}-0 \cdot 6 \% \\
(-3 \cdot 5 \text { to } 2 \cdot 0)\end{array}$ & $\begin{array}{l}-1 \cdot 2 \% \\
(-2 \cdot 4 \text { to } 0 \cdot 0)\end{array}$ \\
\hline Honduras & $\begin{array}{l}153 \cdot 1 \\
(90 \cdot 5 \text { to } 190 \cdot 4)\end{array}$ & $\begin{array}{l}119 \cdot 5 \\
\text { (48.5 to 191.2) }\end{array}$ & $\begin{array}{l}72 \cdot 0 \\
\text { (35.5 to } 123 \cdot 0)\end{array}$ & $\begin{array}{c}295 \\
\text { (175 to } 367)\end{array}$ & $\begin{array}{c}238 \\
\text { (97 to 381) }\end{array}$ & $\begin{array}{c}153 \\
\text { (75 to } 260)\end{array}$ & $\begin{array}{l}-2 \cdot 1 \% \\
(-6 \cdot 4 \text { to } 1 \cdot 5)\end{array}$ & $\begin{array}{l}-5 \cdot 1 \% \\
(-10 \cdot 5 \text { to } 0 \cdot 2)\end{array}$ & $\begin{array}{l}-3 \cdot 4 \% \\
(-5 \cdot 8 \text { to }-1 \cdot 1)\end{array}$ \\
\hline Mexico & $\begin{array}{l}73 \cdot 8 \\
(70 \cdot 4 \text { to } 77 \cdot 1)\end{array}$ & $\begin{array}{l}57 \cdot 9 \\
(55 \cdot 0 \text { to } 60 \cdot 5)\end{array}$ & $\begin{array}{l}54 \cdot 0 \\
\text { (50.3 to } 58 \cdot 2)\end{array}$ & $\begin{array}{c}1774 \\
(1691 \text { to } 1851)\end{array}$ & $\begin{array}{c}1429 \\
(1357 \text { to } 1493)\end{array}$ & $\begin{array}{c}1224 \\
\text { (1139 to } 1320)\end{array}$ & $\begin{array}{l}-1.9 \% \\
(-2 \cdot 3 \text { to }-1 \cdot 5)\end{array}$ & $\begin{array}{l}-0.7 \% \\
(-1.5 \text { to } 0.1)\end{array}$ & $\begin{array}{l}-1 \cdot 4 \% \\
(-1 \cdot 7 \text { to }-1 \cdot 0)\end{array}$ \\
\hline Nicaragua & $\begin{array}{l}94 \cdot 5 \\
\text { (81.2 to } 109 \cdot 4)\end{array}$ & $\begin{array}{l}87 \cdot 8 \\
\text { (76.7 to 101.0) }\end{array}$ & $\begin{array}{l}63 \cdot 5 \\
(49 \cdot 0 \text { to } 80.0)\end{array}$ & $\begin{array}{c}148 \\
\text { (127 to } 171)\end{array}$ & $\begin{array}{c}126 \\
\text { (110 to } 145)\end{array}$ & $\begin{array}{c}90 \\
\text { (69 to } 113 \text { ) }\end{array}$ & $\begin{array}{l}-0.6 \% \\
\text { (-2.1 to } 1.0)\end{array}$ & $\begin{array}{l}-3 \cdot 3 \% \\
(-6 \cdot 2 \text { to }-0 \cdot 7)\end{array}$ & $\begin{array}{l}-1.8 \% \\
(-3.0 \text { to }-0.5)\end{array}$ \\
\hline Panama & $\begin{array}{l}62 \cdot 3 \\
(53 \cdot 0 \text { to } 72 \cdot 7)\end{array}$ & $\begin{array}{l}66 \cdot 2 \\
\text { (57.2 to } 76 \cdot 3)\end{array}$ & $\begin{array}{l}55 \cdot 2 \\
(40 \cdot 6 \text { to } 73 \cdot 2)\end{array}$ & $\begin{array}{c}42 \\
\text { (35 to } 49 \text { ) }\end{array}$ & $\begin{array}{c}50 \\
\text { (44 to } 58)\end{array}$ & $\begin{array}{c}42 \\
\text { (31 to } 56)\end{array}$ & $\begin{array}{l}0.5 \% \\
\text { (-1.1 to } 2 \cdot 2)\end{array}$ & $\begin{array}{l}-1 \cdot 9 \% \\
(-5 \cdot 1 \text { to } 1 \cdot 3)\end{array}$ & $\begin{array}{l}-0.6 \% \\
(-1.9 \text { to } 0.8)\end{array}$ \\
\hline Venezuela & $\begin{array}{l}66.6 \\
\text { (59.6 to } 73.5)\end{array}$ & $\begin{array}{l}62 \cdot 0 \\
\text { (56.3 to 68.7) }\end{array}$ & $\begin{array}{l}54 \cdot 7 \\
(42 \cdot 8 \text { to } 68 \cdot 6)\end{array}$ & $\begin{array}{c}377 \\
\text { (337 to 415) }\end{array}$ & $\begin{array}{c}373 \\
\text { (339 to } 413)\end{array}$ & $\begin{array}{c}336 \\
\text { (263 to } 421)\end{array}$ & $\begin{array}{l}-0.5 \% \\
(-1.6 \text { to } 0.5)\end{array}$ & $\begin{array}{l}-1 \cdot 3 \% \\
(-3 \cdot 8 \text { to } 1 \cdot 2)\end{array}$ & $\begin{array}{l}-0.9 \% \\
(-2.0 \text { to } 0.2)\end{array}$ \\
\hline $\begin{array}{l}\text { Southern } \\
\text { Latin America }\end{array}$ & $\begin{array}{l}55 \cdot 5 \\
\text { (51.1 to 60.2) }\end{array}$ & $\begin{array}{l}51 \cdot 2 \\
(46 \cdot 3 \text { to } 55 \cdot 8)\end{array}$ & $\begin{array}{l}44 \cdot 2 \\
\text { (37.3 to } 51 \cdot 3 \text { ) }\end{array}$ & $\begin{array}{c}603 \\
\text { (555 to 653) }\end{array}$ & $\begin{array}{c}513 \\
(465 \text { to } 560)\end{array}$ & $\begin{array}{c}445 \\
\text { (376 to 518) }\end{array}$ & $\begin{array}{l}-0.6 \% \\
(-1.6 \text { to } 0.2)\end{array}$ & $\begin{array}{l}-1 \cdot 5 \% \\
(-3 \cdot 3 \text { to } 0 \cdot 3)\end{array}$ & $\begin{array}{l}-1.0 \% \\
(-1.8 \text { to }-0.2)\end{array}$ \\
\hline Argentina & $\begin{array}{l}60 \cdot 2 \\
(54 \cdot 9 \text { to } 66 \cdot 0)\end{array}$ & $\begin{array}{l}63 \cdot 3 \\
\text { (57.0 to 69.7) }\end{array}$ & $\begin{array}{l}54 \cdot 7 \\
(45 \cdot 3 \text { to } 64 \cdot 6)\end{array}$ & $\begin{array}{c}434 \\
(396 \text { to } 476)\end{array}$ & $\begin{array}{c}440 \\
\text { (396 to } 484)\end{array}$ & $\begin{array}{c}387 \\
\text { (320 to } 456)\end{array}$ & $\begin{array}{l}0.4 \% \\
(-0.7 \text { to } 1.4)\end{array}$ & $\begin{array}{l}-1 \cdot 5 \% \\
(-3.5 \text { to } 0.5)\end{array}$ & $\begin{array}{l}-0 \cdot 4 \% \\
(-1 \cdot 3 \text { to } 0 \cdot 4)\end{array}$ \\
\hline Chile & $\begin{array}{l}47 \cdot 8 \\
(42 \cdot 3 \text { to } 54 \cdot 3)\end{array}$ & $\begin{array}{l}22 \cdot 0 \\
(19 \cdot 3 \text { to } 25 \cdot 0)\end{array}$ & $\begin{array}{l}18 \cdot 7 \\
(14 \cdot 7 \text { to } 23 \cdot 2)\end{array}$ & $\begin{array}{c}146 \\
\text { (130 to } 166)\end{array}$ & $\begin{array}{c}56 \\
\text { (49 to } 64)\end{array}$ & $\begin{array}{c}47 \\
\text { (37 to } 58 \text { ) }\end{array}$ & $\begin{array}{l}-6.0 \% \\
(-7 \cdot 4 \text { to }-4 \cdot 6)\end{array}$ & $\begin{array}{l}-1 \cdot 7 \% \\
(-4 \cdot 2 \text { to } 0.9)\end{array}$ & $\begin{array}{l}-4 \cdot 1 \% \\
(-5 \cdot 2 \text { to }-3 \cdot 0)\end{array}$ \\
\hline Uruguay & $\begin{array}{l}38 \cdot 7 \\
(32 \cdot 8 \text { to } 45 \cdot 3)\end{array}$ & $\begin{array}{l}32 \cdot 5 \\
\text { (27.4 to 38.1) }\end{array}$ & $\begin{array}{l}22 \cdot 9 \\
\text { (17.3 to 29.4) }\end{array}$ & $\begin{array}{c}23 \\
\text { (19 to } 27)\end{array}$ & $\begin{array}{c}17 \\
\text { (15 to } 20)\end{array}$ & $\begin{array}{r}12 \\
\text { (9 to } 15)\end{array}$ & $\begin{array}{l}-1 \cdot 4 \% \\
(-3 \cdot 0 \text { to } 0 \cdot 3)\end{array}$ & $\begin{array}{l}-3.6 \% \\
(-6.5 \text { to }-0.7)\end{array}$ & $\begin{array}{l}-2 \cdot 3 \% \\
(-3 \cdot 6 \text { to }-1 \cdot 0)\end{array}$ \\
\hline $\begin{array}{l}\text { Tropical } \\
\text { Latin America }\end{array}$ & $\begin{array}{l}75.9 \\
(68.0 \text { to } 84.6)\end{array}$ & $\begin{array}{l}68 \cdot 3 \\
(60 \cdot 9 \text { to } 75 \cdot 6)\end{array}$ & $\begin{array}{l}60.6 \\
(47.5 \text { to } 75 \cdot 6)\end{array}$ & $\begin{array}{c}2818 \\
\text { (2522 to 3139) }\end{array}$ & $\begin{array}{c}2445 \\
\text { (2182 to 2708) }\end{array}$ & $\begin{array}{c}1969 \\
\text { (1542 to 2457) }\end{array}$ & $\begin{array}{l}-0.8 \% \\
(-1.9 \text { to } 0.2)\end{array}$ & $\begin{array}{l}-1 \cdot 2 \% \\
(-3 \cdot 9 \text { to } 1 \cdot 3)\end{array}$ & $\begin{array}{l}-1 \cdot 0 \% \\
(-2 \cdot 2 \text { to } 0.1)\end{array}$ \\
\hline Brazil & $\begin{array}{l}73 \cdot 1 \\
(65 \cdot 0 \text { to } 82.0)\end{array}$ & $\begin{array}{l}66 \cdot 0 \\
\text { (58.4 to } 73.7)\end{array}$ & $\begin{array}{l}58.7 \\
\text { (45.8 to } 73.5)\end{array}$ & $\begin{array}{c}2609 \\
\text { (2320 to 2925) }\end{array}$ & $\begin{array}{c}2265 \\
\text { (2003 to 2530) }\end{array}$ & $\begin{array}{c}1813 \\
\text { (1414 to 2267) }\end{array}$ & $\begin{array}{l}-0.8 \% \\
(-1.9 \text { to } 0.3)\end{array}$ & $\begin{array}{l}-1 \cdot 2 \% \\
(-4 \cdot 0 \text { to } 1 \cdot 4)\end{array}$ & $\begin{array}{l}-1 \cdot 0 \% \\
(-2 \cdot 2 \text { to } 0.2)\end{array}$ \\
\hline Paraguay & $\begin{array}{l}145 \cdot 6 \\
(130 \cdot 2 \text { to } 162 \cdot 4)\end{array}$ & $\begin{array}{l}119 \cdot 8 \\
(107 \cdot 3 \text { to } 134 \cdot 0)\end{array}$ & $\begin{array}{l}95 \cdot 2 \\
\text { (71.6 to 126.9) }\end{array}$ & $\begin{array}{c}209 \\
\text { (187 to 233) }\end{array}$ & $\begin{array}{c}181 \\
\text { (162 to } 202)\end{array}$ & $\begin{array}{c}156 \\
\text { (117 to 208) }\end{array}$ & $\begin{array}{l}-1 \cdot 5 \% \\
(-2 \cdot 7 \text { to }-0.3)\end{array}$ & $\begin{array}{l}-2 \cdot 4 \% \\
(-5 \cdot 3 \text { to } 1.0)\end{array}$ & $\begin{array}{l}-1.9 \% \\
(-3.2 \text { to }-0.5)\end{array}$ \\
\hline $\begin{array}{l}\text { North Africa } \\
\text { and Middle East }\end{array}$ & $\begin{array}{l}131 \cdot 0 \\
(115 \cdot 4 \text { to } 147 \cdot 8)\end{array}$ & $\begin{array}{l}101 \cdot 8 \\
(85 \cdot 1 \text { to } 121 \cdot 3)\end{array}$ & $\begin{array}{l}78.1 \\
(63 \cdot 1 \text { to } 97 \cdot 6)\end{array}$ & $\begin{array}{l}13106 \\
\text { (11543 to } 14783)\end{array}$ & $\begin{array}{l}10370 \\
\text { (8672 to } 12351)\end{array}$ & $\begin{array}{l}8907 \\
\text { (7204 to 11135) }\end{array}$ & $\begin{array}{l}-2.0 \% \\
(-3 \cdot 2 \text { to }-0.9)\end{array}$ & $\begin{array}{l}-2 \cdot 7 \% \\
(-4 \cdot 3 \text { to }-1 \cdot 0)\end{array}$ & $\begin{array}{l}-2 \cdot 3 \% \\
(-3 \cdot 2 \text { to }-1 \cdot 3)\end{array}$ \\
\hline Algeria & $\begin{array}{l}126 \cdot 1 \\
(87.0 \text { to } 170 \cdot 4)\end{array}$ & $\begin{array}{l}81.0 \\
\text { (59.8 to 107.0) }\end{array}$ & $\begin{array}{l}51 \cdot 5 \\
\text { (37.2 to } 70 \cdot 1)\end{array}$ & $\begin{array}{c}949 \\
\text { (655 to } 1283 \text { ) }\end{array}$ & $\begin{array}{c}575 \\
\text { (424 to } 759)\end{array}$ & $\begin{array}{c}470 \\
\text { (340 to } 641 \text { ) }\end{array}$ & $\begin{array}{l}-3.4 \% \\
(-6.5 \text { to } 0.1)\end{array}$ & $\begin{array}{l}-4.5 \% \\
(-8.6 \text { to }-0.5)\end{array}$ & $\begin{array}{l}-3.9 \% \\
(-5.8 \text { to }-2.0)\end{array}$ \\
\hline Bahrain & $\begin{array}{l}55 \cdot 4 \\
(40 \cdot 7 \text { to } 73 \cdot 4)\end{array}$ & $\begin{array}{l}32 \cdot 7 \\
(24 \cdot 9 \text { to } 41 \cdot 9)\end{array}$ & $\begin{array}{l}21 \cdot 4 \\
(15 \cdot 5 \text { to } 29 \cdot 0)\end{array}$ & $\begin{array}{r}7 \\
\text { (5 to } 10)\end{array}$ & $(4 \text { to } 6)^{5}$ & (3 to 6$)^{4}$ & $\begin{array}{l}-4.0 \% \\
(-6.9 \text { to }-1 \cdot 1)\end{array}$ & $\begin{array}{l}-4 \cdot 3 \% \\
(-8 \cdot 0 \text { to } 0.1)\end{array}$ & $\begin{array}{l}-4 \cdot 2 \% \\
(-6 \cdot 1 \text { to }-2 \cdot 2)\end{array}$ \\
\hline Egypt & $\begin{array}{l}83 \cdot 7 \\
(69 \cdot 9 \text { to } 100 \cdot 1)\end{array}$ & $\begin{array}{l}44 \cdot 8 \\
\text { (39.1 to } 51 \cdot 9 \text { ) }\end{array}$ & $\begin{array}{l}32 \cdot 6 \\
(24 \cdot 5 \text { to } 42 \cdot 3)\end{array}$ & $\begin{array}{c}1385 \\
\text { (1157 to } 1656 \text { ) }\end{array}$ & $\begin{array}{c}765 \\
\text { (668 to } 888)\end{array}$ & $\begin{array}{c}619 \\
\text { (465 to } 803)\end{array}$ & $\begin{array}{l}-4 \cdot 8 \% \\
(-6 \cdot 5 \text { to }-3 \cdot 0)\end{array}$ & $\begin{array}{l}-3 \cdot 2 \% \\
(-6 \cdot 2 \text { to }-0 \cdot 3)\end{array}$ & $\begin{array}{l}-4 \cdot 1 \% \\
(-5 \cdot 5 \text { to }-2 \cdot 8)\end{array}$ \\
\hline Iran & $\begin{array}{l}40 \cdot 1 \\
(27 \cdot 0 \text { to } 57 \cdot 2)\end{array}$ & $\begin{array}{l}26 \cdot 6 \\
\text { (21.9 to } 31 \cdot 6)\end{array}$ & $\begin{array}{l}13 \cdot 5 \\
(9 \cdot 4 \text { to } 18 \cdot 3)\end{array}$ & $\begin{array}{c}651 \\
\text { (439 to 929) }\end{array}$ & $\begin{array}{c}333 \\
\text { (275 to 396) }\end{array}$ & $\begin{array}{c}197 \\
\text { (137 to } 266)\end{array}$ & $\begin{array}{l}-3 \cdot 1 \% \\
(-6 \cdot 2 \text { to } 0 \cdot 2)\end{array}$ & $\begin{array}{l}-6 \cdot 9 \% \\
(-10 \cdot 9 \text { to }-3 \cdot 1)\end{array}$ & $\begin{array}{l}-4 \cdot 7 \% \\
(-7 \cdot 0 \text { to }-2 \cdot 6)\end{array}$ \\
\hline Iraq & $\begin{array}{l}110 \cdot 6 \\
(68 \cdot 7 \text { to } 157 \cdot 0)\end{array}$ & $\begin{array}{l}88.0 \\
\text { (62.0 to } 126 \cdot 8)\end{array}$ & $\begin{array}{l}65 \cdot 8 \\
\text { (40.4 to } 110 \cdot 7)\end{array}$ & $\begin{array}{c}736 \\
\text { (457 to 1045) }\end{array}$ & $\begin{array}{c}816 \\
\text { (574 to } 1175)\end{array}$ & $\begin{array}{c}695 \\
\text { (427 to 1170) }\end{array}$ & $\begin{array}{l}-1 \cdot 7 \% \\
(-5 \cdot 6 \text { to } 2 \cdot 5)\end{array}$ & $\begin{array}{l}-3 \cdot 1 \% \\
(-8 \cdot 1 \text { to } 2 \cdot 3)\end{array}$ & $\begin{array}{l}-2 \cdot 3 \% \\
(-4 \cdot 8 \text { to } 0.7)\end{array}$ \\
\hline Jordan & $\begin{array}{l}102 \cdot 2 \\
\text { (79.1 to } 128 \cdot 7)\end{array}$ & $\begin{array}{l}60 \cdot 2 \\
(46 \cdot 2 \text { to } 78 \cdot 8)\end{array}$ & $\begin{array}{l}29.8 \\
(20 \cdot 3 \text { to } 41 \cdot 4)\end{array}$ & $\begin{array}{c}112 \\
\text { (87 to } 141)\end{array}$ & $\begin{array}{c}92 \\
\text { (71 to } 120)\end{array}$ & $\begin{array}{c}57 \\
\text { (39 to } 79 \text { ) }\end{array}$ & $\begin{array}{l}-4 \cdot 1 \% \\
(-6 \cdot 9 \text { to }-1 \cdot 3)\end{array}$ & $\begin{array}{l}-7 \cdot 1 \% \\
(-11 \cdot 8 \text { to }-2 \cdot 2)\end{array}$ & $\begin{array}{l}-5 \cdot 4 \% \\
(-7 \cdot 2 \text { to }-3 \cdot 5)\end{array}$ \\
\hline Kuwait & $\begin{array}{l}17.8 \\
(14 \cdot 4 \text { to } 21 \cdot 6)\end{array}$ & $\begin{array}{l}11 \cdot 4 \\
(9 \cdot 6 \text { to } 13 \cdot 6)\end{array}$ & $\begin{array}{c}9.5 \\
(7.5 \text { to } 12.0)\end{array}$ & $\begin{array}{l}{ }^{6} \\
\text { (5 to } 7)^{-}\end{array}$ & $(5 \text { to } 7)^{5}$ & (5 to 8$)^{7}$ & $\begin{array}{l}-3 \cdot 4 \% \\
(-5 \cdot 4 \text { to }-1 \cdot 4)\end{array}$ & $\begin{array}{l}-1 \cdot 8 \% \\
(-4 \cdot 4 \text { to } 0.8)\end{array}$ & $\begin{array}{l}-2 \cdot 7 \% \\
(-4.0 \text { to }-1 \cdot 4)\end{array}$ \\
\hline Lebanon & $\begin{array}{l}101 \cdot 4 \\
(74 \cdot 8 \text { to } 135 \cdot 1)\end{array}$ & $\begin{array}{l}42 \cdot 4 \\
(30 \cdot 8 \text { to } 56 \cdot 8)\end{array}$ & $\begin{array}{l}18 \cdot 1 \\
\text { (11.9 to 26.0) }\end{array}$ & $\begin{array}{c}65 \\
(48 \text { to } 87)\end{array}$ & $\begin{array}{c}23 \\
(16 \text { to } 30)\end{array}$ & $\begin{array}{r}12 \\
\text { (8 to } 17)\end{array}$ & $\begin{array}{l}-6.7 \% \\
(-9.5 \text { to }-3.9)\end{array}$ & $\begin{array}{l}-8.6 \% \\
(-12 \cdot 7 \text { to }-4.9)\end{array}$ & $\begin{array}{l}-7 \cdot 5 \% \\
(-9.7 \text { to }-5 \cdot 5)\end{array}$ \\
\hline Libya & $\begin{array}{l}41 \cdot 8 \\
(25 \cdot 7 \text { to } 64 \cdot 6)\end{array}$ & $\begin{array}{l}30 \cdot 7 \\
(22 \cdot 8 \text { to } 40 \cdot 5)\end{array}$ & $\begin{array}{l}27.0 \\
(18.0 \text { to } 40.5)\end{array}$ & $\begin{array}{c}46 \\
\text { (28 to } 71)\end{array}$ & $\begin{array}{c}37 \\
\text { (27 to } 49 \text { ) }\end{array}$ & $\begin{array}{c}33 \\
\text { (22 to } 50)\end{array}$ & $\begin{array}{l}-2 \cdot 3 \% \\
(-6.0 \text { to } 1 \cdot 6)\end{array}$ & $\begin{array}{l}-1 \cdot 4 \% \\
(-6.5 \text { to } 3 \cdot 7)\end{array}$ & $\begin{array}{l}-1.9 \% \\
(-4.5 \text { to } 0.8)\end{array}$ \\
\hline Morocco & $\begin{array}{l}279.5 \\
(236.0 \text { to } 338.9)\end{array}$ & $\begin{array}{l}98 \cdot 3 \\
\text { (75.2 to } 120 \cdot 8)\end{array}$ & $\begin{array}{l}63.9 \\
\text { (45.1 to } 85.8)\end{array}$ & $\begin{array}{c}1971 \\
\text { (1664 to 2390) }\end{array}$ & $\begin{array}{c}603 \\
\text { (462 to } 741 \text { ) }\end{array}$ & $\begin{array}{c}472 \\
\text { (334 to 635) }\end{array}$ & $\begin{array}{l}-8 \cdot 1 \% \\
(-10 \cdot 2 \text { to }-6 \cdot 0)\end{array}$ & $\begin{array}{l}-4 \cdot 4 \% \\
(-7 \cdot 5 \text { to }-1 \cdot 3)\end{array}$ & $\begin{array}{l}-6 \cdot 5 \% \\
(-8 \cdot 1 \text { to }-5 \cdot 0)\end{array}$ \\
\hline Oman & $\begin{array}{l}47.0 \\
(26.7 \text { to } 76 \cdot 6)\end{array}$ & $\begin{array}{l}20 \cdot 4 \\
(14 \cdot 2 \text { to } 29 \cdot 4)\end{array}$ & $\begin{array}{l}12 \cdot 8 \\
(8 \cdot 4 \text { to } 20 \cdot 6)\end{array}$ & $\begin{array}{c}30 \\
\text { (17 to } 49 \text { ) }\end{array}$ & $\begin{array}{r}11 \\
\text { (7 to } 15)\end{array}$ & $\begin{array}{r}9 \\
\text { (6 to } 15)\end{array}$ & $\begin{array}{l}-6 \cdot 3 \% \\
(-10 \cdot 8 \text { to }-1 \cdot 7)\end{array}$ & $\begin{array}{l}-4 \cdot 8 \% \\
(-10 \cdot 8 \text { to } 1 \cdot 2)\end{array}$ & $\begin{array}{l}-5 \cdot 6 \% \\
(-8 \cdot 5 \text { to }-2 \cdot 8)\end{array}$ \\
\hline \multirow[t]{2}{*}{ Palestine } & $\begin{array}{l}21 \cdot 1 \\
(12 \cdot 3 \text { to } 34 \cdot 3)\end{array}$ & $\begin{array}{c}11 \cdot 3 \\
(8 \cdot 7 \text { to } 14 \cdot 4)\end{array}$ & $\begin{array}{c}9 \cdot 0 \\
\text { (5.5 to } 13 \cdot 2)\end{array}$ & $\begin{array}{c}22 \\
\text { (13 to } 35)\end{array}$ & $\begin{array}{c}13 \\
\text { (10 to } 17)\end{array}$ & $\begin{array}{r}12 \\
\text { (7 to } 17)\end{array}$ & $\begin{array}{l}-4.6 \% \\
(-9.0 \text { to }-0.4)\end{array}$ & $\begin{array}{l}-2 \cdot 5 \% \\
(-7 \cdot 5 \text { to } 2 \cdot 3)\end{array}$ & $\begin{array}{l}-3.7 \% \\
(-6.8 \text { to }-0.7)\end{array}$ \\
\hline & & & & & & & & \multicolumn{2}{|c|}{ (Table 1 continues on next page) } \\
\hline
\end{tabular}




\begin{tabular}{|c|c|c|c|c|c|c|c|c|c|}
\hline & \multicolumn{3}{|c|}{ Maternal mortality ratio (per 100000 livebirths) } & \multicolumn{3}{|c|}{ Number of maternal deaths } & \multicolumn{3}{|c|}{$\begin{array}{l}\text { Annualised rate of change in maternal } \\
\text { mortality ratio }(\%)\end{array}$} \\
\hline & 1990 & 2003 & 2013 & 1990 & 2003 & 2013 & $1990-2003$ & $2003-13$ & 1990-2013 \\
\hline \multicolumn{10}{|c|}{ (Continued from previous page) } \\
\hline Qatar & $\begin{array}{l}50 \cdot 4 \\
(36 \cdot 2 \text { to } 69 \cdot 8)\end{array}$ & $\begin{array}{l}38 \cdot 9 \\
(29 \cdot 6 \text { to } 50 \cdot 1)\end{array}$ & $\begin{array}{l}18 \cdot 7 \\
(12 \cdot 4 \text { to } 27 \cdot 2)\end{array}$ & $(4 \text { to } 7)^{5}$ & $(3 \text { to } 6)^{4}$ & $(3 \text { to } 6)^{4}$ & $\begin{array}{l}-2 \cdot 0 \% \\
(-5 \cdot 1 \text { to } 1 \cdot 0)\end{array}$ & $\begin{array}{l}-7 \cdot 4 \% \\
(-12 \cdot 2 \text { to }-2 \cdot 8)\end{array}$ & $\begin{array}{l}-4 \cdot 3 \% \\
(-6 \cdot 6 \text { to }-2 \cdot 2)\end{array}$ \\
\hline Saudi Arabia & $\begin{array}{l}15 \cdot 7 \\
(9 \cdot 1 \text { to } 25 \cdot 2)\end{array}$ & $\begin{array}{c}9 \cdot 3 \\
(7 \cdot 6 \text { to } 11 \cdot 1)\end{array}$ & $\begin{array}{c}7 \cdot 0 \\
(5 \cdot 2 \text { to } 9 \cdot 2)\end{array}$ & $\begin{array}{c}88 \\
\text { (51 to } 140)\end{array}$ & $\begin{array}{c}49 \\
(41 \text { to } 59)\end{array}$ & $\begin{array}{c}38 \\
(28 \text { to } 50)\end{array}$ & $\begin{array}{l}-3 \cdot 8 \% \\
(-7 \cdot 9 \text { to } 0.6)\end{array}$ & $\begin{array}{l}-2 \cdot 8 \% \\
(-6.2 \text { to } 0.5)\end{array}$ & $\begin{array}{l}-3 \cdot 4 \% \\
(-5 \cdot 8 \text { to }-0.8)\end{array}$ \\
\hline Sudan & $\begin{array}{l}407 \cdot 8 \\
(304 \cdot 2 \text { to } 502 \cdot 9)\end{array}$ & $\begin{array}{l}356 \cdot 5 \\
(237 \cdot 6 \text { to } 478 \cdot 8)\end{array}$ & $\begin{array}{l}275 \cdot 2 \\
(181 \cdot 1 \text { to } 377 \cdot 5)\end{array}$ & $\begin{array}{c}3558 \\
(2654 \text { to } 4388)\end{array}$ & $\begin{array}{c}4193 \\
\text { (2794 to 5631) }\end{array}$ & $\begin{array}{c}3528 \\
(2322 \text { to } 4840)\end{array}$ & $\begin{array}{l}-1 \cdot 1 \% \\
(-3 \cdot 5 \text { to } 1 \cdot 1)\end{array}$ & $\begin{array}{l}-2 \cdot 6 \% \\
(-5 \cdot 4 \text { to } 0 \cdot 2)\end{array}$ & $\begin{array}{l}-1 \cdot 8 \% \\
(-3 \cdot 3 \text { to }-0.2)\end{array}$ \\
\hline Syria & $\begin{array}{l}120.5 \\
(86.0 \text { to } 158.8)\end{array}$ & $\begin{array}{c}64 \cdot 8 \\
\text { (49.1 to 80.9) }\end{array}$ & $\begin{array}{c}44 \cdot 1 \\
(31 \cdot 1 \text { to } 60 \cdot 3)\end{array}$ & $\begin{array}{c}513 \\
(367 \text { to } 676)\end{array}$ & $\begin{array}{c}309 \\
(235 \text { to } 386)\end{array}$ & $\begin{array}{c}229 \\
(161 \text { to } 313)\end{array}$ & $\begin{array}{l}-4 \cdot 7 \% \\
(-7 \cdot 7 \text { to }-1 \cdot 8)\end{array}$ & $\begin{array}{l}-3 \cdot 9 \% \\
(-7 \cdot 7 \text { to } 0.1)\end{array}$ & $\begin{array}{l}-4 \cdot 4 \% \\
(-6 \cdot 4 \text { to }-2 \cdot 4)\end{array}$ \\
\hline Tunisia & $\begin{array}{l}62 \cdot 2 \\
(44 \cdot 4 \text { to } 82 \cdot 7)\end{array}$ & $\begin{array}{c}28 \cdot 5 \\
(18 \cdot 4 \text { to } 42 \cdot 3)\end{array}$ & $\begin{array}{l}19.0 \\
(11.6 \text { to } 28 \cdot 5)\end{array}$ & $\begin{array}{c}124 \\
\text { (88 to } 164)\end{array}$ & $\begin{array}{c}48 \\
(31 \text { to } 72)\end{array}$ & $\begin{array}{c}35 \\
\text { (21 to } 53)\end{array}$ & $\begin{array}{l}-6 \cdot 1 \% \\
(-9 \cdot 7 \text { to }-2 \cdot 4)\end{array}$ & $\begin{array}{l}-4 \cdot 1 \% \\
(-9 \cdot 1 \text { to } 0.7)\end{array}$ & $\begin{array}{l}-5 \cdot 2 \% \\
(-7 \cdot 6 \text { to }-3 \cdot 0)\end{array}$ \\
\hline Turkey & $\begin{array}{l}48 \cdot 5 \\
(34 \cdot 7 \text { to } 65 \cdot 2)\end{array}$ & $\begin{array}{c}23 \cdot 1 \\
(17 \cdot 1 \text { to } 30 \cdot 9)\end{array}$ & $\begin{array}{c}15 \cdot 0 \\
\text { (10.7 to } 19 \cdot 9)\end{array}$ & $\begin{array}{c}664 \\
\text { (475 to 893) }\end{array}$ & $\begin{array}{c}304 \\
(226 \text { to } 408)\end{array}$ & $\begin{array}{c}188 \\
(134 \text { to } 250)\end{array}$ & $\begin{array}{l}-5 \cdot 7 \% \\
(-8 \cdot 9 \text { to }-2 \cdot 6)\end{array}$ & $\begin{array}{l}-4 \cdot 3 \% \\
(-8 \cdot 4 \text { to }-0.1)\end{array}$ & $\begin{array}{l}-5 \cdot 1 \% \\
(-6 \cdot 9 \text { to }-3 \cdot 2)\end{array}$ \\
\hline $\begin{array}{l}\text { United } \\
\text { Arab Emirates }\end{array}$ & $\begin{array}{l}55 \cdot 8 \\
(31 \cdot 0 \text { to } 112 \cdot 1)\end{array}$ & $\begin{array}{c}21 \cdot 6 \\
(14 \cdot 1 \text { to } 33 \cdot 7)\end{array}$ & $\begin{array}{c}12 \cdot 8 \\
\text { (7.7 to } 21 \cdot 4)\end{array}$ & $\begin{array}{c}23 \\
(13 \text { to } 47)\end{array}$ & $\begin{array}{r}12 \\
(8 \text { to } 18)\end{array}$ & $\begin{array}{c}17 \\
(10 \text { to } 29)\end{array}$ & $\begin{array}{l}-7 \cdot 1 \% \\
(-11 \cdot 9 \text { to }-2 \cdot 4)\end{array}$ & $\begin{array}{l}-5 \cdot 3 \% \\
(-10 \cdot 2 \text { to } 1 \cdot 0)\end{array}$ & $\begin{array}{l}-6 \cdot 3 \% \\
(-9 \cdot 5 \text { to }-3 \cdot 0)\end{array}$ \\
\hline Yemen & $\begin{array}{l}342 \cdot 6 \\
(182 \cdot 1 \text { to } 519 \cdot 2)\end{array}$ & $\begin{array}{l}322 \cdot 2 \\
(182 \cdot 7 \text { to } 524 \cdot 9)\end{array}$ & $\begin{array}{l}308.8 \\
(168.6 \text { to } 555.4)\end{array}$ & $\begin{array}{c}2151 \\
\text { (1143 to 3260) }\end{array}$ & $\begin{array}{c}2172 \\
\text { (1232 to 3538) }\end{array}$ & $\begin{array}{c}2279 \\
\text { (1244 to 4099) }\end{array}$ & $\begin{array}{l}-0.5 \% \\
\text { (-3.5 to } 2.7)\end{array}$ & $\begin{array}{l}-0.5 \% \\
(-3.8 \text { to } 3.3)\end{array}$ & $\begin{array}{l}-0.5 \% \\
(-2.8 \text { to } 2 \cdot 2)\end{array}$ \\
\hline $\begin{array}{l}\text { High-income } \\
\text { North America }\end{array}$ & $\begin{array}{c}11 \cdot 9 \\
(10 \cdot 7 \text { to } 13 \cdot 3)\end{array}$ & $\begin{array}{c}17 \cdot 0 \\
(15 \cdot 1 \text { to } 18 \cdot 8)\end{array}$ & $\begin{array}{c}17 \cdot 6 \\
(14 \cdot 3 \text { to } 21 \cdot 6)\end{array}$ & $\begin{array}{c}555 \\
(499 \text { to } 621)\end{array}$ & $\begin{array}{c}784 \\
\text { (697 to 867) }\end{array}$ & $\begin{array}{c}829 \\
(672 \text { to } 1016)\end{array}$ & $\begin{array}{l}2.7 \% \\
(1.5 \text { to } 3.8)\end{array}$ & $\begin{array}{l}0.3 \% \\
\text { (-1.8 to } 2.6)\end{array}$ & $\begin{array}{l}1.7 \% \\
\text { (0.7 to } 2 \cdot 6)\end{array}$ \\
\hline Canada & $\begin{array}{c}7 \cdot 1 \\
(6 \cdot 0 \text { to } 8 \cdot 3)\end{array}$ & $\begin{array}{c}9 \cdot 2 \\
(7 \cdot 6 \text { to } 10 \cdot 7)\end{array}$ & $\begin{array}{c}8 \cdot 2 \\
(6 \cdot 3 \text { to } 10 \cdot 3)\end{array}$ & $\begin{array}{c}28 \\
\text { (24 to } 33)\end{array}$ & $\begin{array}{c}32 \\
\text { (27 to } 37)\end{array}$ & $\begin{array}{c}33 \\
(25 \text { to } 42)\end{array}$ & $\begin{array}{c}2.0 \% \\
(0.2 \text { to } 3 \cdot 6)\end{array}$ & $\begin{array}{l}-1 \cdot 2 \% \\
(-3 \cdot 7 \text { to } 1 \cdot 3)\end{array}$ & $\begin{array}{l}0.6 \% \\
(-0.7 \text { to } 1.9)\end{array}$ \\
\hline USA & $\begin{array}{l}12 \cdot 4 \\
(11 \cdot 1 \text { to } 13 \cdot 9)\end{array}$ & $\begin{array}{c}17 \cdot 6 \\
(15 \cdot 7 \text { to } 19 \cdot 5)\end{array}$ & $\begin{array}{l}18 \cdot 5 \\
(14 \cdot 8 \text { to } 22 \cdot 9)\end{array}$ & $\begin{array}{c}527 \\
(472 \text { to } 592)\end{array}$ & $\begin{array}{c}752 \\
\text { (669 to 833) }\end{array}$ & $\begin{array}{c}796 \\
\text { (638 to 985) }\end{array}$ & $\begin{array}{l}2.7 \% \\
(1.4 \text { to } 3.8)\end{array}$ & $\begin{array}{l}0.5 \% \\
(-1.8 \text { to } 2.8)\end{array}$ & $\begin{array}{l}1.7 \% \\
(0.8 \text { to } 2 \cdot 7)\end{array}$ \\
\hline Oceania & $\begin{array}{l}599 \cdot 9 \\
(365 \cdot 3 \text { to } 972 \cdot 5)\end{array}$ & $\begin{array}{l}577 \cdot 8 \\
(331 \cdot 4 \text { to } 976 \cdot 3)\end{array}$ & $\begin{array}{l}494 \cdot 1 \\
(264 \cdot 4 \text { to } 849 \cdot 3)\end{array}$ & $\begin{array}{c}1234 \\
\text { (752 to 2001) }\end{array}$ & $\begin{array}{c}1461 \\
\text { (838 to 2469) }\end{array}$ & $\begin{array}{c}1325 \\
\text { (709 to 2278) }\end{array}$ & $\begin{array}{l}-0 \cdot 3 \% \\
(-3 \cdot 3 \text { to } 2 \cdot 7)\end{array}$ & $\begin{array}{l}-1 \cdot 6 \% \\
(-5 \cdot 2 \text { to } 2 \cdot 4)\end{array}$ & $\begin{array}{l}-0 \cdot 9 \% \\
(-3 \cdot 2 \text { to } 1 \cdot 7)\end{array}$ \\
\hline $\begin{array}{l}\text { Federated } \\
\text { States of } \\
\text { Micronesia }\end{array}$ & $\begin{array}{l}170 \cdot 3 \\
(82 \cdot 9 \text { to } 310 \cdot 8)\end{array}$ & $\begin{array}{l}130 \cdot 5 \\
(66 \cdot 6 \text { to } 235 \cdot 5)\end{array}$ & $\begin{array}{l}87 \cdot 9 \\
(44 \cdot 7 \text { to } 154 \cdot 5)\end{array}$ & $\begin{array}{r}6 \\
\text { (3 to 10) }\end{array}$ & (2 to 7$)^{4}$ & (1 to 4$)^{2}$ & $\begin{array}{l}-2.0 \% \\
(-6.0 \text { to } 2 \cdot 0)\end{array}$ & $\begin{array}{l}-3.9 \% \\
(-8.5 \text { to } 0.7)\end{array}$ & $\begin{array}{l}-2.9 \% \\
(-5.6 \text { to } 0.0)\end{array}$ \\
\hline Fiji & $\begin{array}{l}109 \cdot 6 \\
(68 \cdot 4 \text { to } 165 \cdot 2)\end{array}$ & $\begin{array}{l}100 \cdot 8 \\
(72 \cdot 0 \text { to } 135 \cdot 5)\end{array}$ & $\begin{array}{l}68 \cdot 2 \\
(43 \cdot 7 \text { to } 102 \cdot 8)\end{array}$ & $\begin{array}{c}24 \\
(15 \text { to } 36)\end{array}$ & $\begin{array}{c}19 \\
(14 \text { to } 26)\end{array}$ & $\begin{array}{c}12 \\
(8 \text { to } 18)\end{array}$ & $\begin{array}{l}-0.6 \% \\
(-4.4 \text { to } 3.6)\end{array}$ & $\begin{array}{l}-4.0 \% \\
(-9.0 \text { to } 0.8)\end{array}$ & $\begin{array}{l}-2 \cdot 1 \% \\
(-4 \cdot 9 \text { to } 0.7)\end{array}$ \\
\hline Kiribati & $\begin{array}{l}213 \cdot 3 \\
(153 \cdot 9 \text { to } 296 \cdot 9)\end{array}$ & $\begin{array}{l}142 \cdot 4 \\
(97 \cdot 1 \text { to } 216 \cdot 5)\end{array}$ & $\begin{array}{l}100 \cdot 9 \\
(57 \cdot 4 \text { to } 169 \cdot 1)\end{array}$ & (4 to 8$)^{6}$ & $(2 \text { to } 5)^{3}$ & (1 to 4) & $\begin{array}{l}-3 \cdot 2 \% \\
(-7 \cdot 1 \text { to } 0 \cdot 8)\end{array}$ & $\begin{array}{l}-3.6 \% \\
(-9.0 \text { to } 1.8)\end{array}$ & $\begin{array}{l}-3 \cdot 4 \% \\
(-6 \cdot 2 \text { to }-0.6)\end{array}$ \\
\hline $\begin{array}{l}\text { Marshall } \\
\text { Islands }\end{array}$ & $\begin{array}{l}74 \cdot 7 \\
(46 \cdot 2 \text { to } 111 \cdot 8)\end{array}$ & $\begin{array}{l}109 \cdot 4 \\
(66 \cdot 3 \text { to } 167 \cdot 8)\end{array}$ & $\begin{array}{l}95 \cdot 6 \\
\text { (51.9 to 164.9) }\end{array}$ & (1 to 2$)^{2}$ & $(1 \text { to } 3)^{2}$ & (1 to 3$)^{2}$ & $\begin{array}{l}2.9 \% \\
\text { (-1.6 to } 7.4)\end{array}$ & $\begin{array}{l}-1 \cdot 5 \% \\
(-7.8 \text { to } 5 \cdot 1)\end{array}$ & $\begin{array}{l}1.0 \% \\
(-2 \cdot 0 \text { to } 4.0)\end{array}$ \\
\hline $\begin{array}{l}\text { Papua } \\
\text { New Guinea }\end{array}$ & $\begin{array}{l}765 \cdot 9 \\
(456 \cdot 7 \text { to } 1255 \cdot 9)\end{array}$ & $\begin{array}{l}702 \cdot 6 \\
(396 \cdot 4 \text { to } 1197 \cdot 8)\end{array}$ & $\begin{array}{l}594 \cdot 2 \\
(312 \cdot 7 \text { to } 1030 \cdot 8)\end{array}$ & $\begin{array}{c}1148 \\
\text { (684 to } 1882)\end{array}$ & $\begin{array}{c}1382 \\
\text { (779 to } 2355)\end{array}$ & $\begin{array}{c}1260 \\
(663 \text { to } 2187)\end{array}$ & $\begin{array}{l}-0 \cdot 7 \% \\
(-3 \cdot 8 \text { to } 2 \cdot 4)\end{array}$ & $\begin{array}{l}-1 \cdot 7 \% \\
(-5 \cdot 4 \text { to } 2 \cdot 3)\end{array}$ & $\begin{array}{l}-1 \cdot 1 \% \\
(-3 \cdot 6 \text { to } 1 \cdot 5)\end{array}$ \\
\hline Samoa & $\begin{array}{l}61 \cdot 1 \\
(36 \cdot 2 \text { to } 99 \cdot 7)\end{array}$ & $\begin{array}{c}51 \cdot 2 \\
(32 \cdot 5 \text { to } 76 \cdot 3)\end{array}$ & $\begin{array}{c}41 \cdot 4 \\
(26 \cdot 9 \text { to } 62 \cdot 8)\end{array}$ & $(2 \text { to } 5)^{3}$ & $(2 \text { to } 4)^{3}$ & (1 to 3$)^{2}$ & $\begin{array}{l}-1 \cdot 3 \% \\
(-6 \cdot 0 \text { to } 3 \cdot 3)\end{array}$ & $\begin{array}{l}-2 \cdot 1 \% \\
(-7.0 \text { to } 3.3)\end{array}$ & $\begin{array}{l}-1 \cdot 6 \% \\
(-4 \cdot 6 \text { to } 1 \cdot 1)\end{array}$ \\
\hline $\begin{array}{l}\text { Solomon } \\
\text { Islands }\end{array}$ & $\begin{array}{l}254 \cdot 0 \\
(127 \cdot 4 \text { to } 454 \cdot 4)\end{array}$ & $\begin{array}{l}214 \cdot 5 \\
(112 \cdot 5 \text { to } 379 \cdot 3)\end{array}$ & $\begin{array}{l}183.0 \\
(95 \cdot 9 \text { to } 338 \cdot 5)\end{array}$ & $\begin{array}{c}32 \\
(16 \text { to } 56)\end{array}$ & $\begin{array}{c}34 \\
(18 \text { to } 60)\end{array}$ & $\begin{array}{c}32 \\
\text { (17 to 59) }\end{array}$ & $\begin{array}{l}-1 \cdot 3 \% \\
(-5 \cdot 2 \text { to } 2 \cdot 7)\end{array}$ & $\begin{array}{l}-1.6 \% \\
(-6.0 \text { to } 3 \cdot 2)\end{array}$ & $\begin{array}{l}-1 \cdot 4 \% \\
(-4 \cdot 5 \text { to } 1 \cdot 6)\end{array}$ \\
\hline Tonga & $\begin{array}{l}188 \cdot 1 \\
(118 \cdot 8 \text { to } 286 \cdot 9)\end{array}$ & $\begin{array}{l}143 \cdot 3 \\
(108 \cdot 8 \text { to } 185 \cdot 6)\end{array}$ & $\begin{array}{l}111 \cdot 2 \\
(68 \cdot 2 \text { to } 172 \cdot 2)\end{array}$ & (4 to 9) & ${ }^{4}{ }^{4}$ & $(2 \text { to } 5)^{3}$ & $\begin{array}{l}-2.0 \% \\
(-6.0 \text { to } 1.8)\end{array}$ & $\begin{array}{l}-2 \cdot 7 \% \\
(-7 \cdot 8 \text { to } 2 \cdot 3)\end{array}$ & $\begin{array}{l}-2 \cdot 3 \% \\
(-5 \cdot 0 \text { to } 0.4)\end{array}$ \\
\hline Vanuatu & $\begin{array}{l}176 \cdot 3 \\
(83 \cdot 5 \text { to } 329 \cdot 7)\end{array}$ & $\begin{array}{l}174 \cdot 8 \\
(88 \cdot 2 \text { to } 333 \cdot 0)\end{array}$ & $\begin{array}{l}139 \cdot 2 \\
(72 \cdot 3 \text { to } 257 \cdot 6)\end{array}$ & $\begin{array}{r}10 \\
(5 \text { to } 18)\end{array}$ & $\begin{array}{r}10 \\
(5 \text { to } 20)\end{array}$ & $\begin{array}{r}9 \\
(5 \text { to } 17)\end{array}$ & $\begin{array}{l}-0 \cdot 1 \% \\
(-4 \cdot 2 \text { to } 4 \cdot 1)\end{array}$ & $\begin{array}{l}-2 \cdot 2 \% \\
(-6.6 \text { to } 2 \cdot 4)\end{array}$ & $\begin{array}{l}-1 \cdot 0 \% \\
(-4 \cdot 0 \text { to } 2 \cdot 2)\end{array}$ \\
\hline $\begin{array}{l}\text { Central sub- } \\
\text { Saharan Africa }\end{array}$ & $\begin{array}{l}456 \cdot 3 \\
(366 \cdot 2 \text { to } 546 \cdot 7)\end{array}$ & $\begin{array}{l}419.1 \\
(341.2 \text { to } 499 \cdot 8)\end{array}$ & $\begin{array}{l}353 \cdot 1 \\
(279 \cdot 9 \text { to } 434 \cdot 1)\end{array}$ & $\begin{array}{l}12178 \\
\text { (9773 to } 14591)\end{array}$ & $\begin{array}{l}15191 \\
\text { (12369 to } 18118)\end{array}$ & $\begin{array}{l}15355 \\
\text { (12174 to } 18880)\end{array}$ & $\begin{array}{l}-0.7 \% \\
\text { (-2.2 to } 0.8)\end{array}$ & $\begin{array}{l}-1 \cdot 7 \% \\
(-3 \cdot 8 \text { to } 0 \cdot 3)\end{array}$ & $\begin{array}{l}-1 \cdot 1 \% \\
(-2 \cdot 3 \text { to } 0 \cdot 1)\end{array}$ \\
\hline Angola & $\begin{array}{l}510 \cdot 6 \\
\text { (324.9 to } 747 \cdot 3 \text { ) }\end{array}$ & $\begin{array}{l}451.1 \\
(308.9 \text { to } 657.8)\end{array}$ & $\begin{array}{l}310 \cdot 1 \\
(198 \cdot 3 \text { to } 472 \cdot 2)\end{array}$ & $\begin{array}{c}2976 \\
\text { (1894 to 4356) }\end{array}$ & $\begin{array}{c}3672 \\
\text { (2515 to } 5355)\end{array}$ & $\begin{array}{c}3032 \\
\text { (1939 to 4618) }\end{array}$ & $\begin{array}{l}-0.9 \% \\
(-3.7 \text { to } 1.8)\end{array}$ & $\begin{array}{l}-3.8 \% \\
(-7 \cdot 1 \text { to }-0.5)\end{array}$ & $\begin{array}{l}-2 \cdot 2 \% \\
(-4 \cdot 0 \text { to } 0.0)\end{array}$ \\
\hline $\begin{array}{l}\text { Central } \\
\text { African } \\
\text { Republic }\end{array}$ & $\begin{array}{l}788 \cdot 7 \\
(576 \cdot 4 \text { to } 1020 \cdot 1)\end{array}$ & $\begin{array}{l}999 \cdot 4 \\
(636 \cdot 2 \text { to } 1415 \cdot 6)\end{array}$ & $\begin{array}{l}910 \cdot 5 \\
(578 \cdot 3 \text { to } 1293 \cdot 2)\end{array}$ & $\begin{array}{c}973 \\
\text { (711 to } 1258)\end{array}$ & $\begin{array}{c}1473 \\
\text { (937 to 2086) }\end{array}$ & $\begin{array}{c}1459 \\
\text { (926 to 2072) }\end{array}$ & $\begin{array}{l}1.8 \% \\
(-0.7 \text { to } 3.9)\end{array}$ & $\begin{array}{l}-0.9 \% \\
(-3.8 \text { to } 1.7)\end{array}$ & $\begin{array}{l}0.6 \% \\
\text { (-1.0 to } 2.0)\end{array}$ \\
\hline Congo & $\begin{array}{l}397 \cdot 2 \\
(275 \cdot 6 \text { to } 545 \cdot 1)\end{array}$ & $\begin{array}{l}482 \cdot 8 \\
(322 \cdot 1 \text { to } 673 \cdot 7)\end{array}$ & $\begin{array}{l}287 \cdot 3 \\
(189.6 \text { to } 427 \cdot 1)\end{array}$ & $\begin{array}{c}379 \\
\text { (263 to 519) }\end{array}$ & $\begin{array}{c}678 \\
(452 \text { to } 946)\end{array}$ & $\begin{array}{c}494 \\
\text { (326 to } 735)\end{array}$ & $\begin{array}{l}1.5 \% \\
\text { (-1.1 to } 3 \cdot 9)\end{array}$ & $\begin{array}{l}-5 \cdot 2 \% \\
(-8 \cdot 5 \text { to }-2 \cdot 0)\end{array}$ & $\begin{array}{l}-1 \cdot 4 \% \\
(-3 \cdot 4 \text { to } 0 \cdot 4)\end{array}$ \\
\hline DR Congo & $\begin{array}{l}420 \cdot 1 \\
(323 \cdot 5 \text { to } 521 \cdot 5)\end{array}$ & $\begin{array}{l}369.5 \\
(295.0 \text { to } 451.4)\end{array}$ & $\begin{array}{l}342 \cdot 3 \\
(251 \cdot 4 \text { to } 446 \cdot 7)\end{array}$ & $\begin{array}{c}7616 \\
\text { (5865 to 9455) }\end{array}$ & $\begin{array}{l}9069 \\
\text { (7241 to } 11081)\end{array}$ & $\begin{array}{l}10125 \\
\text { (7437 to } 13213 \text { ) }\end{array}$ & $\begin{array}{l}-1 \cdot 0 \% \\
(-3 \cdot 1 \text { to } 1 \cdot 3)\end{array}$ & $\begin{array}{l}-0.8 \% \\
(-3.7 \text { to } 1.8)\end{array}$ & $\begin{array}{l}-0.9 \% \\
(-2.6 \text { to } 0.7)\end{array}$ \\
\hline $\begin{array}{l}\text { Equatorial } \\
\text { Guinea }\end{array}$ & $\begin{array}{l}599 \cdot 9 \\
(376 \cdot 2 \text { to } 897 \cdot 0)\end{array}$ & $\begin{array}{l}487 \cdot 3 \\
(280 \cdot 4 \text { to } 736 \cdot 7)\end{array}$ & $\begin{array}{l}369.6 \\
(199.8 \text { to } 620.0)\end{array}$ & $\begin{array}{c}109 \\
(68 \text { to } 163)\end{array}$ & $\begin{array}{c}110 \\
(63 \text { to } 166)\end{array}$ & $\begin{array}{c}100 \\
(54 \text { to } 168)\end{array}$ & $\begin{array}{l}-1 \cdot 6 \% \\
(-5 \cdot 4 \text { to } 2 \cdot 3)\end{array}$ & $\begin{array}{l}-2.9 \% \\
(-6.9 \text { to } 1.4)\end{array}$ & $\begin{array}{l}-2 \cdot 2 \% \\
(-4 \cdot 9 \text { to } 0.9)\end{array}$ \\
\hline
\end{tabular}




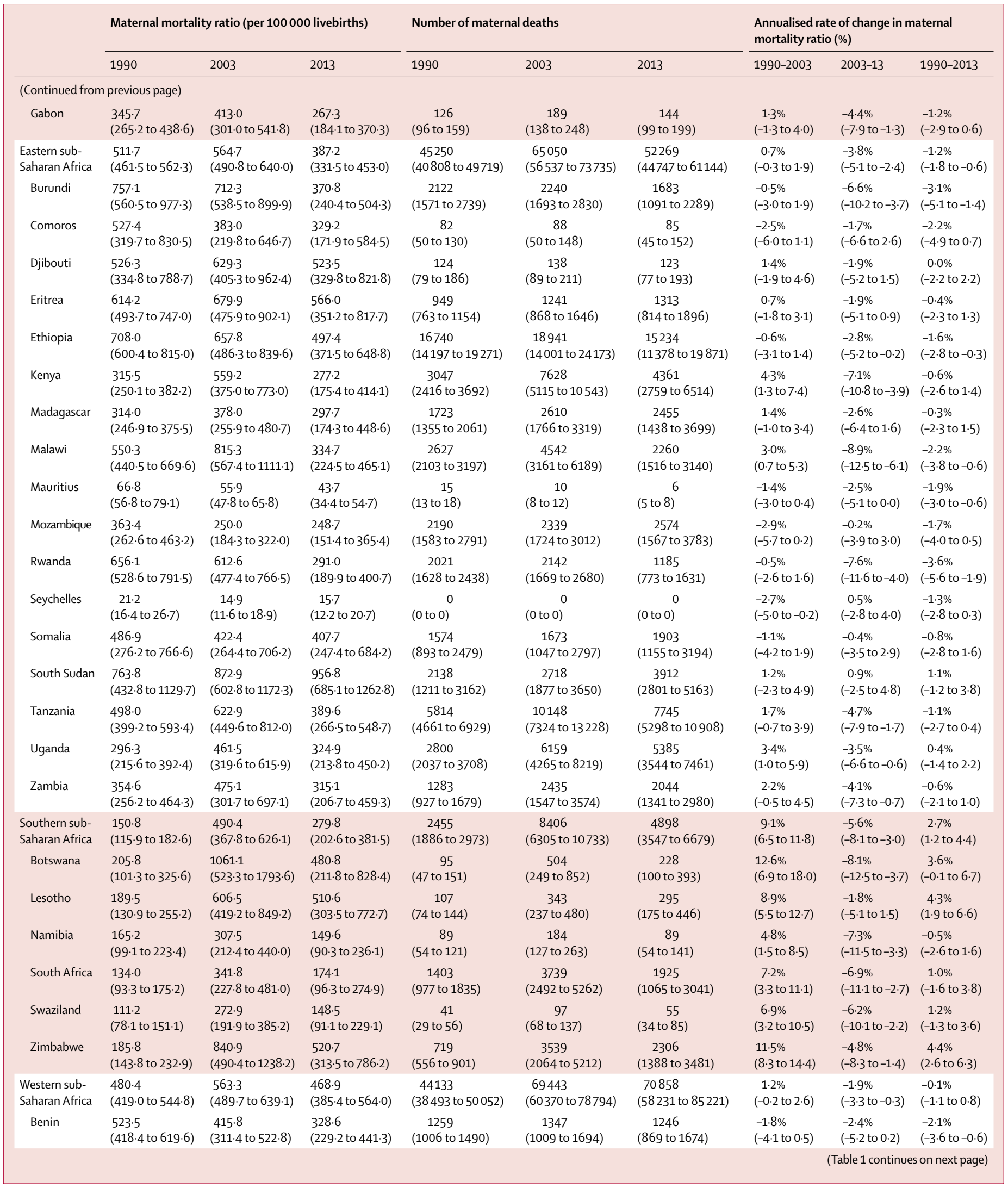




\begin{tabular}{|c|c|c|c|c|c|c|c|c|c|}
\hline & \multicolumn{3}{|c|}{ Maternal mortality ratio (per 100000 livebirths) } & \multicolumn{3}{|c|}{ Number of maternal deaths } & \multicolumn{3}{|c|}{$\begin{array}{l}\text { Annualised rate of change in maternal } \\
\text { mortality ratio (\%) }\end{array}$} \\
\hline & 1990 & 2003 & 2013 & 1990 & 2003 & 2013 & 1990-2003 & $2003-13$ & 1990-2013 \\
\hline \multicolumn{10}{|c|}{ (Continued from previous page) } \\
\hline Burkina Faso & $\begin{array}{l}301 \cdot 5 \\
(224 \cdot 9 \text { to } 383 \cdot 1)\end{array}$ & $\begin{array}{l}409 \cdot 2 \\
(307 \cdot 2 \text { to } 517 \cdot 5)\end{array}$ & $\begin{array}{l}310 \cdot 5 \\
(223 \cdot 1 \text { to } 406 \cdot 2)\end{array}$ & $\begin{array}{l}1325 \\
\text { (989 to } 1684)\end{array}$ & $\begin{array}{c}2443 \\
\text { (1834 to } 3090)\end{array}$ & $\begin{array}{c}2185 \\
\text { (1570 to 2858) }\end{array}$ & $\begin{array}{l}2 \cdot 3 \% \\
(0 \cdot 1 \text { to } 4 \cdot 6)\end{array}$ & $\begin{array}{l}-2 \cdot 8 \% \\
(-6 \cdot 1 \text { to } 0 \cdot 3)\end{array}$ & $\begin{array}{l}0.1 \% \\
(-1.5 \text { to } 1.6)\end{array}$ \\
\hline Cameroon & $\begin{array}{l}436 \cdot 4 \\
(351 \cdot 7 \text { to } 510 \cdot 0)\end{array}$ & $\begin{array}{l}614 \cdot 4 \\
(472 \cdot 3 \text { to } 789 \cdot 3)\end{array}$ & $\begin{array}{l}564 \cdot 6 \\
(414 \cdot 0 \text { to } 743 \cdot 6)\end{array}$ & $\begin{array}{c}2451 \\
(1975 \text { to } 2865)\end{array}$ & $\begin{array}{c}4476 \\
\text { (3441 to } 5750)\end{array}$ & $\begin{array}{c}4772 \\
\text { (3499 to 6285) }\end{array}$ & $\begin{array}{l}2 \cdot 6 \% \\
(0.5 \text { to } 5 \cdot 0)\end{array}$ & $\begin{array}{l}-0 \cdot 9 \% \\
(-3 \cdot 4 \text { to } 1 \cdot 4)\end{array}$ & $\begin{array}{l}1 \cdot 1 \% \\
(-0 \cdot 4 \text { to } 2 \cdot 6)\end{array}$ \\
\hline Cape Verde & $\begin{array}{l}110 \cdot 4 \\
(83 \cdot 5 \text { to } 138 \cdot 3)\end{array}$ & $\begin{array}{l}80 \cdot 5 \\
(47 \cdot 8 \text { to } 128 \cdot 1)\end{array}$ & $\begin{array}{l}47 \cdot 6 \\
(27 \cdot 9 \text { to } 76 \cdot 2)\end{array}$ & $\begin{array}{c}15 \\
(11 \text { to } 19)\end{array}$ & $\begin{array}{r}9 \\
(5 \text { to } 15)\end{array}$ & $(3 \text { to } 8)^{5}$ & $\begin{array}{l}-2 \cdot 6 \% \\
(-6 \cdot 6 \text { to } 1 \cdot 2)\end{array}$ & $\begin{array}{l}-5 \cdot 3 \% \\
(-11 \cdot 2 \text { to } 0 \cdot 4)\end{array}$ & $\begin{array}{l}-3 \cdot 8 \% \\
(-6 \cdot 2 \text { to }-1 \cdot 4)\end{array}$ \\
\hline Chad & $\begin{array}{l}429 \cdot 8 \\
\text { (352.9 to } 510 \cdot 2)\end{array}$ & $\begin{array}{l}659.2 \\
(506.9 \text { to } 808.4)\end{array}$ & $\begin{array}{l}597.6 \\
(408.4 \text { to } 809.5)\end{array}$ & $\begin{array}{c}1424 \\
(1170 \text { to } 1691)\end{array}$ & $\begin{array}{c}3245 \\
\text { (2496 to } 3980)\end{array}$ & $\begin{array}{c}3593 \\
\text { (2456 to 4868) }\end{array}$ & $\begin{array}{l}3 \cdot 3 \% \\
(1 \cdot 3 \text { to } 5 \cdot 3)\end{array}$ & $\begin{array}{l}-1 \cdot 1 \% \\
(-3 \cdot 8 \text { to } 1 \cdot 3)\end{array}$ & $\begin{array}{l}1.4 \% \\
\text { (-0.3 to } 2 \cdot 9)\end{array}$ \\
\hline Côte d'Ivoire & $\begin{array}{l}496 \cdot 9 \\
(374 \cdot 7 \text { to } 606 \cdot 4)\end{array}$ & $\begin{array}{l}729 \cdot 8 \\
(521.8 \text { to } 968 \cdot 7)\end{array}$ & $\begin{array}{l}501 \cdot 5 \\
(354 \cdot 3 \text { to } 653 \cdot 9)\end{array}$ & $\begin{array}{c}2539 \\
\text { (1915 to 3099) }\end{array}$ & $\begin{array}{c}4771 \\
\text { (3411 to 6333) }\end{array}$ & $\begin{array}{c}3824 \\
\text { (2702 to 4987) }\end{array}$ & $\begin{array}{l}2.9 \% \\
(0.5 \text { to } 5 \cdot 2)\end{array}$ & $\begin{array}{l}-3 \cdot 7 \% \\
(-6 \cdot 8 \text { to }-0.9)\end{array}$ & $\begin{array}{l}0.0 \% \\
(-1.4 \text { to } 1 \cdot 3)\end{array}$ \\
\hline Ghana & $\begin{array}{l}374 \cdot 3 \\
(247 \cdot 7 \text { to } 528 \cdot 1)\end{array}$ & $\begin{array}{l}418 \cdot 1 \\
(309 \cdot 6 \text { to } 532 \cdot 9)\end{array}$ & $\begin{array}{l}293 \cdot 4 \\
(193 \cdot 5 \text { to } 410 \cdot 4)\end{array}$ & $\begin{array}{c}2143 \\
\text { (1418 to 3024) }\end{array}$ & $\begin{array}{c}2933 \\
\text { (2172 to 3739) }\end{array}$ & $\begin{array}{c}2343 \\
\text { (1545 to 3277) }\end{array}$ & $\begin{array}{l}0.9 \% \\
(-2 \cdot 6 \text { to } 4 \cdot 7)\end{array}$ & $\begin{array}{l}-3 \cdot 6 \% \\
(-7 \cdot 3 \text { to }-0 \cdot 3)\end{array}$ & $\begin{array}{l}-1 \cdot 1 \% \\
(-3 \cdot 6 \text { to } 1 \cdot 4)\end{array}$ \\
\hline Guinea & $\begin{array}{l}660 \cdot 4 \\
(564 \cdot 4 \text { to } 768 \cdot 8)\end{array}$ & $\begin{array}{l}676 \cdot 3 \\
(542 \cdot 1 \text { to } 811 \cdot 8)\end{array}$ & $\begin{array}{l}615 \cdot 4 \\
(470 \cdot 5 \text { to } 781 \cdot 9)\end{array}$ & $\begin{array}{c}1966 \\
\text { (1680 to 2289) }\end{array}$ & $\begin{array}{c}2642 \\
\text { (2118 to 3171) }\end{array}$ & $\begin{array}{c}2720 \\
\text { (2080 to 3457) }\end{array}$ & $\begin{array}{l}0.2 \% \\
(-1 \cdot 7 \text { to } 1 \cdot 8)\end{array}$ & $\begin{array}{l}-1 \cdot 0 \% \\
(-3 \cdot 1 \text { to } 1 \cdot 0)\end{array}$ & $\begin{array}{l}-0.3 \% \\
\text { (-1.6 to } 0.9)\end{array}$ \\
\hline $\begin{array}{l}\text { Guinea- } \\
\text { Bissau }\end{array}$ & $\begin{array}{l}708 \cdot 1 \\
(417 \cdot 3 \text { to } 1052 \cdot 9)\end{array}$ & $\begin{array}{l}837 \cdot 7 \\
(573 \cdot 6 \text { to } 1154 \cdot 5)\end{array}$ & $\begin{array}{l}885 \cdot 3 \\
(616 \cdot 5 \text { to } 1230 \cdot 2)\end{array}$ & $\begin{array}{c}334 \\
\text { (197 to 497) }\end{array}$ & $\begin{array}{c}478 \\
\text { (327 to 659) }\end{array}$ & $\begin{array}{c}576 \\
\text { (401 to 800) }\end{array}$ & $\begin{array}{l}1.4 \% \\
(-1.6 \text { to } 4.5)\end{array}$ & $\begin{array}{l}0.6 \% \\
\text { (-2.3 to } 3 \cdot 5)\end{array}$ & $\begin{array}{l}1.0 \% \\
(-1.0 \text { to } 3.0)\end{array}$ \\
\hline Liberia & $\begin{array}{l}630 \cdot 1 \\
(487 \cdot 9 \text { to } 782 \cdot 0)\end{array}$ & $\begin{array}{l}779 \cdot 5 \\
(605 \cdot 3 \text { to } 962 \cdot 1)\end{array}$ & $\begin{array}{l}627 \cdot 3 \\
(467 \cdot 5 \text { to } 793 \cdot 2)\end{array}$ & $\begin{array}{c}624 \\
\text { (483 to } 775)\end{array}$ & $\begin{array}{c}1038 \\
\text { (806 to } 1281)\end{array}$ & $\begin{array}{c}974 \\
(726 \text { to } 1232)\end{array}$ & $\begin{array}{l}1.6 \% \\
(-0.8 \text { to } 4.1)\end{array}$ & $\begin{array}{l}-2 \cdot 2 \% \\
(-4 \cdot 6 \text { to } 0 \cdot 1)\end{array}$ & $\begin{array}{l}0.0 \% \\
(-1.6 \text { to } 1.4)\end{array}$ \\
\hline Mali & $\begin{array}{l}573 \cdot 0 \\
(500 \cdot 0 \text { to } 649 \cdot 8)\end{array}$ & $\begin{array}{l}506 \cdot 7 \\
(415 \cdot 9 \text { to } 603 \cdot 8)\end{array}$ & $\begin{array}{l}388 \cdot 3 \\
(300 \cdot 6 \text { to } 487 \cdot 3)\end{array}$ & $\begin{array}{c}2326 \\
\text { (2030 to 2638) }\end{array}$ & $\begin{array}{c}2936 \\
\text { (2410 to 3499) }\end{array}$ & $\begin{array}{c}2966 \\
\text { (2295 to 3722) }\end{array}$ & $\begin{array}{l}-1 \cdot 0 \% \\
(-2 \cdot 5 \text { to } 0.7)\end{array}$ & $\begin{array}{l}-2 \cdot 7 \% \\
(-5 \cdot 0 \text { to }-0.5)\end{array}$ & $\begin{array}{l}-1 \cdot 7 \% \\
(-2 \cdot 9 \text { to }-0.5)\end{array}$ \\
\hline Mauritania & $\begin{array}{l}680 \cdot 6 \\
(585 \cdot 6 \text { to } 789 \cdot 8)\end{array}$ & $\begin{array}{l}681 \cdot 0 \\
(501 \cdot 2 \text { to } 856 \cdot 1)\end{array}$ & $\begin{array}{l}568 \cdot 8 \\
(363 \cdot 6 \text { to } 793 \cdot 6)\end{array}$ & $\begin{array}{c}580 \\
(499 \text { to } 673)\end{array}$ & $\begin{array}{c}772 \\
\text { (568 to } 971)\end{array}$ & $\begin{array}{c}761 \\
\text { (487 to } 1062 \text { ) }\end{array}$ & $\begin{array}{l}0.0 \% \\
(-2 \cdot 4 \text { to } 1.8)\end{array}$ & $\begin{array}{l}-1 \cdot 9 \% \\
(-4 \cdot 6 \text { to } 0 \cdot 6)\end{array}$ & $\begin{array}{l}-0.8 \% \\
(-2 \cdot 7 \text { to } 0.7)\end{array}$ \\
\hline Niger & $\begin{array}{l}481 \cdot 0 \\
(394 \cdot 4 \text { to } 567 \cdot 6)\end{array}$ & $\begin{array}{l}427 \cdot 3 \\
(348 \cdot 3 \text { to } 523 \cdot 0)\end{array}$ & $\begin{array}{l}406 \cdot 5 \\
(308 \cdot 2 \text { to } 505 \cdot 0)\end{array}$ & $\begin{array}{c}2217 \\
(1818 \text { to } 2616)\end{array}$ & $\begin{array}{c}2920 \\
\text { (2379 to 3573) }\end{array}$ & $\begin{array}{c}3873 \\
\text { (2936 to 4811) }\end{array}$ & $\begin{array}{l}-0.9 \% \\
(-2 \cdot 7 \text { to } 0.9)\end{array}$ & $\begin{array}{l}-0 \cdot 5 \% \\
(-2 \cdot 9 \text { to } 1 \cdot 7)\end{array}$ & $\begin{array}{l}-0 \cdot 7 \% \\
(-2 \cdot 1 \text { to } 0 \cdot 5)\end{array}$ \\
\hline Nigeria & $\begin{array}{l}483.2 \\
(359.9 \text { to } 608 \cdot 4)\end{array}$ & $\begin{array}{l}585 \cdot 7 \\
(445 \cdot 6 \text { to } 717 \cdot 8)\end{array}$ & $\begin{array}{l}496 \cdot 4 \\
(335 \cdot 9 \text { to } 666 \cdot 2)\end{array}$ & $\begin{array}{l}21233 \\
\text { (15814 to 26737) }\end{array}$ & $\begin{array}{l}34810 \\
\text { (26480 to } 42656)\end{array}$ & $\begin{array}{l}36698 \\
\text { (24829 to } 49252)\end{array}$ & $\begin{array}{l}1.5 \% \\
(-1 \cdot 2 \text { to } 4.0)\end{array}$ & $\begin{array}{l}-1.7 \% \\
(-4.4 \text { to } 0.9)\end{array}$ & $\begin{array}{l}0.1 \% \\
(-1.8 \text { to } 1.9)\end{array}$ \\
\hline $\begin{array}{l}\text { SãoTomé and } \\
\text { Príncipe }\end{array}$ & $\begin{array}{l}297 \cdot 5 \\
(211 \cdot 4 \text { to } 395 \cdot 6)\end{array}$ & $\begin{array}{l}195 \cdot 7 \\
(133 \cdot 1 \text { to } 251 \cdot 6)\end{array}$ & $\begin{array}{l}134 \cdot 9 \\
(65 \cdot 2 \text { to } 208 \cdot 6)\end{array}$ & $\begin{array}{r}13 \\
\text { (9 to } 18)\end{array}$ & $\begin{array}{r}11 \\
\text { (8 to } 14)\end{array}$ & $\begin{array}{r}9 \\
(4 \text { to } 14)\end{array}$ & $\begin{array}{l}-3 \cdot 2 \% \\
(-6.6 \text { to }-0.1)\end{array}$ & $\begin{array}{l}-4 \cdot 0 \% \\
(-9.5 \text { to } 0.9)\end{array}$ & $\begin{array}{l}-3 \cdot 6 \% \\
(-6 \cdot 5 \text { to }-1 \cdot 0)\end{array}$ \\
\hline Senegal & $\begin{array}{l}518 \cdot 8 \\
(441 \cdot 9 \text { to } 601 \cdot 7)\end{array}$ & $\begin{array}{l}462 \cdot 2 \\
(366 \cdot 1 \text { to } 557 \cdot 3)\end{array}$ & $\begin{array}{l}347 \cdot 2 \\
(249 \cdot 2 \text { to } 455 \cdot 2)\end{array}$ & $\begin{array}{c}1727 \\
(1471 \text { to } 2003)\end{array}$ & $\begin{array}{c}2018 \\
\text { (1598 to 2433) }\end{array}$ & $\begin{array}{c}1881 \\
\text { (1350 to 2466) }\end{array}$ & $\begin{array}{l}-0.9 \% \\
(-2.9 \text { to } 0.9)\end{array}$ & $\begin{array}{l}-2 \cdot 9 \% \\
(-5 \cdot 5 \text { to }-0.5)\end{array}$ & $\begin{array}{l}-1 \cdot 8 \% \\
(-3 \cdot 2 \text { to }-0 \cdot 5)\end{array}$ \\
\hline Sierra Leone & $\begin{array}{l}521 \cdot 4 \\
(383 \cdot 9 \text { to } 668 \cdot 2)\end{array}$ & $\begin{array}{l}665 \cdot 1 \\
(535 \cdot 3 \text { to } 795 \cdot 8)\end{array}$ & $\begin{array}{l}622 \cdot 6 \\
(447 \cdot 9 \text { to } 790 \cdot 5)\end{array}$ & $\begin{array}{c}943 \\
\text { (694 to 1209) }\end{array}$ & $\begin{array}{c}1360 \\
\text { (1095 to 1627) }\end{array}$ & $\begin{array}{c}1399 \\
\text { (1006 to 1776) }\end{array}$ & $\begin{array}{l}1.9 \% \\
(-0.6 \text { to } 4.3)\end{array}$ & $\begin{array}{l}-0.7 \% \\
(-3 \cdot 4 \text { to } 1.6)\end{array}$ & $\begin{array}{l}0.8 \% \\
(-1.0 \text { to } 2 \cdot 3)\end{array}$ \\
\hline The Gambia & $\begin{array}{l}444 \cdot 4 \\
(230 \cdot 1 \text { to } 685 \cdot 5)\end{array}$ & $\begin{array}{l}368 \cdot 2 \\
(191 \cdot 4 \text { to } 580 \cdot 8)\end{array}$ & $\begin{array}{l}264 \cdot 5 \\
(135 \cdot 5 \text { to } 434 \cdot 7)\end{array}$ & $\begin{array}{c}205 \\
(106 \text { to } 316)\end{array}$ & $\begin{array}{c}232 \\
\text { (121 to } 366)\end{array}$ & $\begin{array}{c}216 \\
(111 \text { to } 356)\end{array}$ & $\begin{array}{l}-1 \cdot 4 \% \\
(-5 \cdot 0 \text { to } 2 \cdot 4)\end{array}$ & $\begin{array}{l}-3.3 \% \\
(-6 \cdot 9 \text { to } 0 \cdot 6)\end{array}$ & $\begin{array}{l}-2.2 \% \\
(-5.0 \text { to } 0.6)\end{array}$ \\
\hline Togo & $\begin{array}{l}496 \cdot 7 \\
(407 \cdot 1 \text { to } 603 \cdot 8)\end{array}$ & $\begin{array}{l}477 \cdot 4 \\
(332 \cdot 4 \text { to } 644 \cdot 0)\end{array}$ & $\begin{array}{l}326 \cdot 2 \\
(210 \cdot 7 \text { to } 473 \cdot 0)\end{array}$ & $\begin{array}{c}807 \\
\text { (662 to } 981)\end{array}$ & $\begin{array}{c}1001 \\
\text { (697 to } 1350)\end{array}$ & $\begin{array}{c}817 \\
\text { (528 to 1185) }\end{array}$ & $\begin{array}{l}-0 \cdot 4 \% \\
(-3 \cdot 1 \text { to } 2 \cdot 2)\end{array}$ & $\begin{array}{l}-3 \cdot 9 \% \\
(-7 \cdot 4 \text { to }-0.4)\end{array}$ & $\begin{array}{l}-1 \cdot 9 \% \\
(-3 \cdot 8 \text { to }-0.1)\end{array}$ \\
\hline
\end{tabular}

Bethesda, MD, USA (XChe PhD); annualised rate of change from 2003 to 2013 to predict Cyprus University of Technology, the MMR for 2030. For countries with an increasing Limassol, Cyprus (CA Christophi PhD); Cedars-Sinai Medical Centre, Los Angeles, CA, USA (ProfS S Chugh MD): University of Salerno, Baronissi, Italy (Prof M Cirillo MD); Mayo Clinic, Rochester, MN, USA (LT Cooper MD); Medical Research Council Lifecourse Epidemiology Unit, University of Southampton, Southampton, UK (Prof C Cooper FMedSci); National School of Public Health (ENSP/Fiocruz), Rio de Janeiro, Brazil (I da Costa Leite PhD); Public Health Foundation of India, New Delhi, India (Prof L Dandona, R Dandona PhD, MMR in that period, we assumed that the MMR would remain constant. We used UN Population Division forecasts of the population aged 15-49 years and births to forecast the number of maternal deaths for each country. We calculated annualised rate of change for 1990-2013 using the continuous rate-of-change formula. Achievement of the MDG 5 target would be equivalent to a sustained 5.5\% decrease per year from 1990 to 2015 .

\section{Uncertainty}

We report 95\% uncertainty intervals (UIs) for maternal deaths, the MMR, causes of maternal death, timing of maternal deaths, and annualised rates of change. The ensemble models for maternal mortality generate
1000 draws from the posterior distribution; the validity of the UIs was confirmed through 50 iterations of crossvalidation with data held out during CODEm estimation. Additionally, DisMod-MR produced 1000 draws from the posterior distribution for the cause analysis and time-ofdeath analysis. We assumed uncertainty in the estimated fraction of maternal deaths due to each cause or the estimated fraction of maternal deaths in different timings to be independent of the uncertainty in the occurrence of maternal mortality. We calculated uncertainty with 1000 draws from the posterior distribution of every step of the estimation process, which allows for quantification and propagation of uncertainty associated with each of the epidemiological variables in the GBD framework. These UIs are different from confidence intervals, which would only quantify 
sampling uncertainty in the underlying data for a specific model.

\section{Role of the funding source}

The funder of the study had no role in study design, data collection, data analysis, data interpretation, or writing of the report. The authors had access to the data in the study and had final responsibility for the decision to submit for publication.

\section{Results}

The total annual number of maternal deaths decreased from 376034 (95\% UI 343 483-407574) in 1990, to 292982 (261017-327792) in 2013 (figure 3A, table 1). The reduction accelerated steadily from 1990 to 2013 (figure 3B), with corresponding decreases in MMR (table 1). Between 2003 and 2013, the annual rate of change in MMR was greater than $-1 \%$, reaching $-3 \cdot 3 \%$ for 2012-13 (figure 3B).

MMR was highest in the oldest age groups and lowest in women aged 20-29 years in both 1990 and 2013 (figure 4). However, it decreased significantly between 1990 and 2013 for almost all age groups (figure 4). We used data for the proportions of births in different maternal age groups and calculated that $9.5 \%$ of maternal deaths are in the group aged 15-19 years, $43 \cdot 1 \%$ in women aged $20-29$ years, and $47.0 \%$ in those aged 30 years and older, with the remainder occurring in the group aged 10-14 years. Despite much higher rates of mortality in older age groups, the total number of deaths is roughly equal before and after the age of 30 years. The MMR in mothers aged 15-19 years in 2013 was 1.5 times higher than that in women aged 20-24 years, and 1.4 times higher than in those aged 25-29 years. In 2013, the MMR was 9.5 times higher for a woman aged 45-49 years (1374.4, 95\% UI 1117.1-1694.9) than for a woman aged 20-24 years $(144 \cdot 1,120 \cdot 6-169 \cdot 9)$.

We recorded substantial differences across the GBD regions in the trends in maternal deaths and the MMR (figure 5). Of the regions where the MMR was more than 300 in 1990, south Asia made the greatest progress by 2013 (figure 5A, table 1). In eastern and western subSaharan Africa, MMRs increased until 2005, but have since reduced substantially (figure 5A). The MMR in eastern sub-Saharan Africa has been changing at a rate of $-4 \cdot 5 \%$ per year (95\% UI $-6 \cdot 0$ to $-2 \cdot 8)$ since 2005.

Of regions that had MMRs of 100-300 in 1990, southeast Asia has had the most notable decreases (figure 5B). The MMR in the Caribbean has followed a similar trend to eastern and western sub-Saharan Africa-ie, increasing to 2005, before falling — and it has improved only slightly in north Africa and the Middle East (figure 5B). The MMR in southern sub-Saharan Africa increased greatly between 1990 and 2006, rising from 150.8 (95\% UI $115 \cdot 9-182 \cdot 6)$ to $565 \cdot 7(420 \cdot 1-737 \cdot 2)$, but then fell to $279 \cdot 8(202 \cdot 6-381 \cdot 5)$ in 2013 (figure 5B).

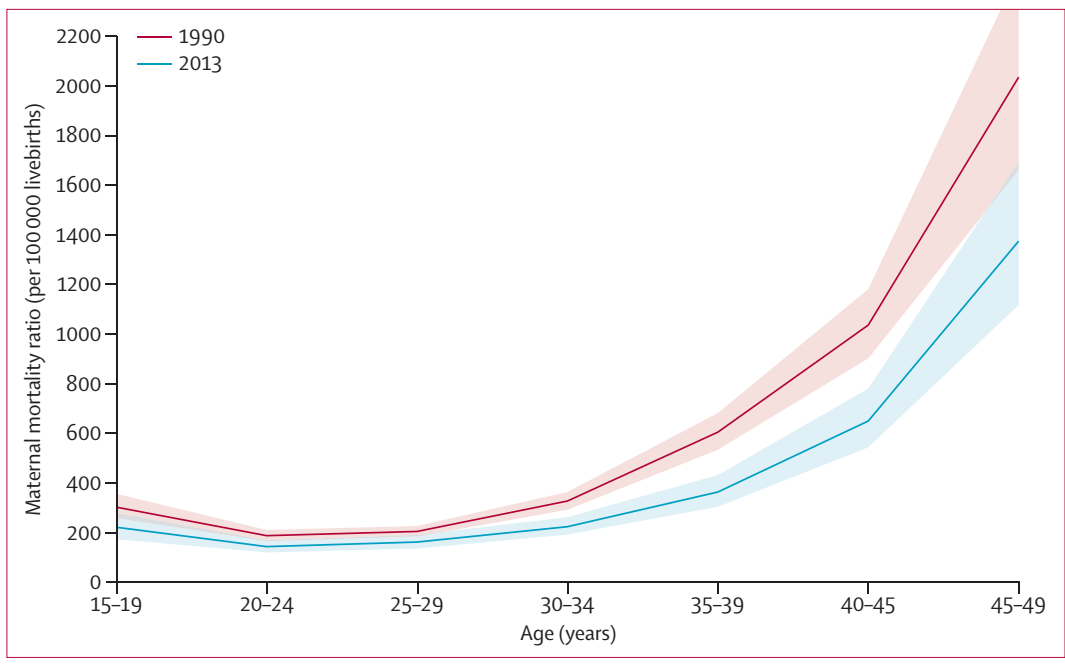

Figure 4: Global maternal mortality ratio in 1990 and 2013, by age Shaded areas show $95 \%$ uncertainty intervals.

We recorded decreases in MMRs in all regions that had an MMR of 30-100 in 1990 (figure 5C, table 1). This reduction is particularly evident in east Asia (figure 5C, table 1). The rates of change in southern Latin America and central Latin America since 2000 seem to have been slower than those before 2000 (figure 5C). In regions with low MMR in $1990(<30)$, the MMR has continued to reduce slowly, except for in the high-income region of North America (figure 5D, table 1).

Except for late maternal deaths and HIV-related deaths, the absolute numbers of deaths due to every cause decreased significantly $(\mathrm{p}<0 \cdot 001)$ from 1990 to 2013 (table 2, appendix). However, in sub-Saharan Africa, the number of deaths due to all causes increased from 1990 to 2013 (table 1). Globally, the biggest absolute reduction was in deaths due to maternal haemorrhage: from 71295 (95\% UI 64562-78329) in 1990, to 44190 (38273-50819) in 2013. The biggest percentage decrease was in maternal sepsis, which caused $11.6 \%(11.4-11 \cdot 8)$ of all maternal deaths in 1990, but $9 \cdot 7 \%(9 \cdot 5-9 \cdot 9)$ in 2013 (figure 6A). The proportion of maternal deaths due to indirect causes increased slightly from $9 \cdot 1 \%$ (95\% UI 8.9-9.4) in 1990, to $10 \cdot 2 \%(10 \cdot 0-10 \cdot 5)$ in 2013 (figure 6A). Additionally, the proportion of maternal deaths due to other direct causes rose from $16 \cdot 5 \%(95 \%$ UI $16 \cdot 3-16 \cdot 8)$ in 1990 , to $17 \cdot 0 \%(16 \cdot 7-17 \cdot 3)$ in 2013 (figure 6A). The number of late maternal deaths decreased globally by $3 \cdot 0 \%$, from 44814 (95\% UI 36414-53106) in 1990, to 43507 (35667-52 395) deaths in 2013. In 2013, HIV accounted for $1.5 \%(0 \cdot 9-2 \cdot 0)$ of all maternal deaths in sub-Saharan Africa, but only $0 \cdot 4 \%(0 \cdot 2-0 \cdot 6)$ worldwide. The number of abortion-related deaths decreased significantly at the global level ( $\mathrm{p}=0.002$; figure $6 \mathrm{~A})$ and in all regions other than Oceania, where no significant change occurred $(\mathrm{p}=0 \cdot 35)$, and sub-Saharan Africa, where the number of deaths increased significantly after abortion $(p<0 \cdot 001)$.
G A Kumar PhD, R B Kumar MD); Public Health England, London, UK (Prof A Davis PhD); School of Medicine (A Dayama MD), Emory University, Atlanta, GA, USA (ProfY Liu PhD, S B Omer PhD); The Kirby Institute (A) Vallely PhD), University of New South Wales, Sydney, NSW, Australia (Prof L Degenhardt PhD); Griffith University, Brisbane, QLD, Australia (Prof D De Leo DSc); University of Auckland, Auckland, New Zealand (B del Pozo-Cruz PhD); Africa Medical and Research Foundation in Ethiopia, Addis Ababa, Ethiopia (M Dessalegn MPH); Hospital fo Sick Children, University of Toronto, Toronto, ON, Canada (G A deVeber MD); University of Peradeniya, Peradeniya, Sri Lanka (SD Dharmaratne MD); Harvard School of Public Health (E L Ding $S C D$ ), Harvard University, Boston, MA, USA (ProfJ A Salomon PhD); Hatte Institute for Cardiovascular Research in Africa, Faculty of Health Sciences (Prof K Sliwa PhD), University of Cape Town, Cape Town, South Africa (Prof RE Dorrington MPhil); Sydney School of Public Health (TR Driscoll PhD), University of Sydney, NSW, Australia (J Leigh PhD); The Institute of Social and Economic Studies of Population at the Russian Academy of Sciences, Moscow, Russia (Prof S P Ermakov DSc); Non-Communicable Diseases Research Centre (F Farzadfar MD); 


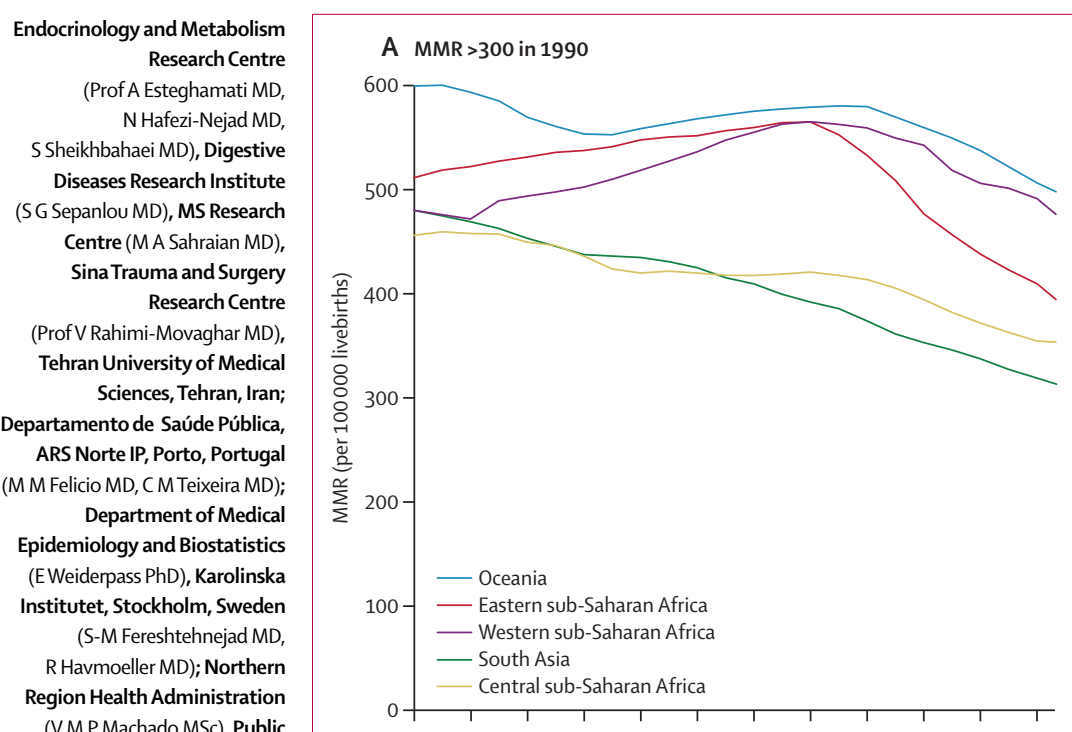

(VMP Pachado MSc), Public Health Department, Unidade Local de Saúde de Matosinhos, Porto, Portugal

(G M Ferreira de Lima BSC); Federal University of Minas Gerais, Belo Horizonte, Brazil (E B Franca PhD); National Centre for Disease Control and Public Health of Georgia, Tbilisi, Georgia (K Gambashidze MS,

K Kazanjan MS, M Kereselidze MD, M Shakh-Nazarova MS, LSturua PhD); Clinique Coopérative de Parakou, Parakou, Borgou, Benin (F G Gankpé MD); Public Health Unit of Primary Health Care Group of Almada-Seixal, Almada, Setúbal, Portugal

(A C Garcia MPH); Division of Human Nutrition, Wageningen

University, Wageningen,

Netherlands (J M Geleijnse PhD); Monash University, Melbourne, VIC, Australia (K B Gibney MBBS, B K Lloyd PhD); University

Hospital of Dijon, Dijon, France (Prof M Giroud MD); Heller School for Social Policy and

Management (EL Llaser MA) Brandeis University, Waltham,

MA, USA (BT Idrisov MD,

EA Undurraga PhD); Ministry of

Labour, Health and Social Affairs, Tbilisi, Georgia

(K Goginashvili MPH); University

of Massachusetts Medical

School, Worcester, MA, USA

(Prof P Gona PhD); National

Institute of Public Health,

Cuernavaca, Mexico

(D González-Castell MSC, I B Heredia Pi PhD,

F Mejia-Rodriguez MSc,

JC Montañez Hernandez MSc,

T G Sánchez Pimienta MSc, EE Servan-Mori MSc,

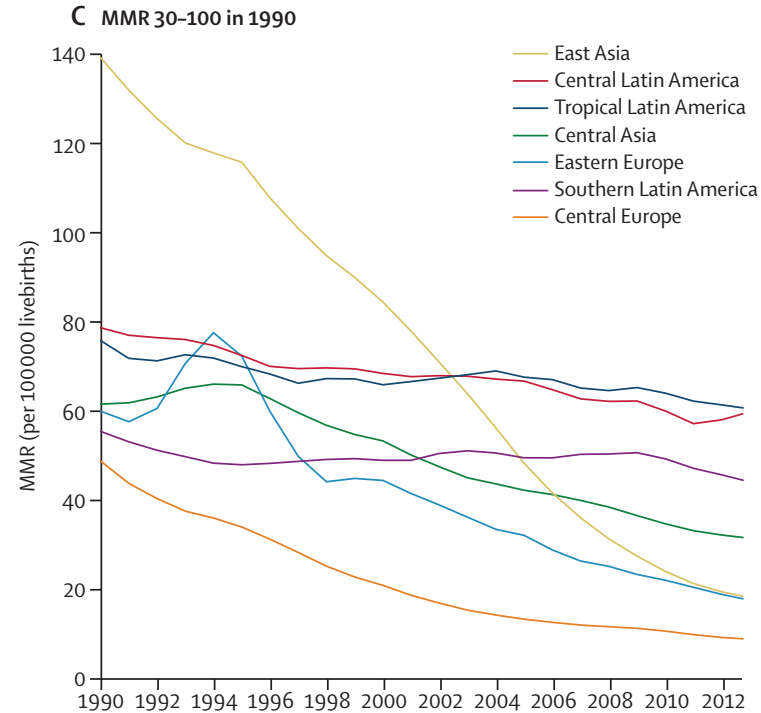

Year

Figure 5: Change in MMR between 1990 and 2013, by region

$M M R=$ maternal mortality ratio.

Cause patterns vary by regions. The two most important causes of maternal death in high-income regions in 2013 were indirect and other direct causes (figure 6B), owing largely to a decrease in abortionrelated deaths, which was the most important cause of maternal mortality in high-income regions in 1990. The number of deaths due to haemorrhage, hypertension, and maternal sepsis have also decreased significantly, whereas the numbers of deaths due to indirect and late maternal causes have increased since 1990 (figure 6B, appendix). By contrast, the most important causes in low-income countries-other direct, abortion, and haemorrhage-have not changed between 1990 and
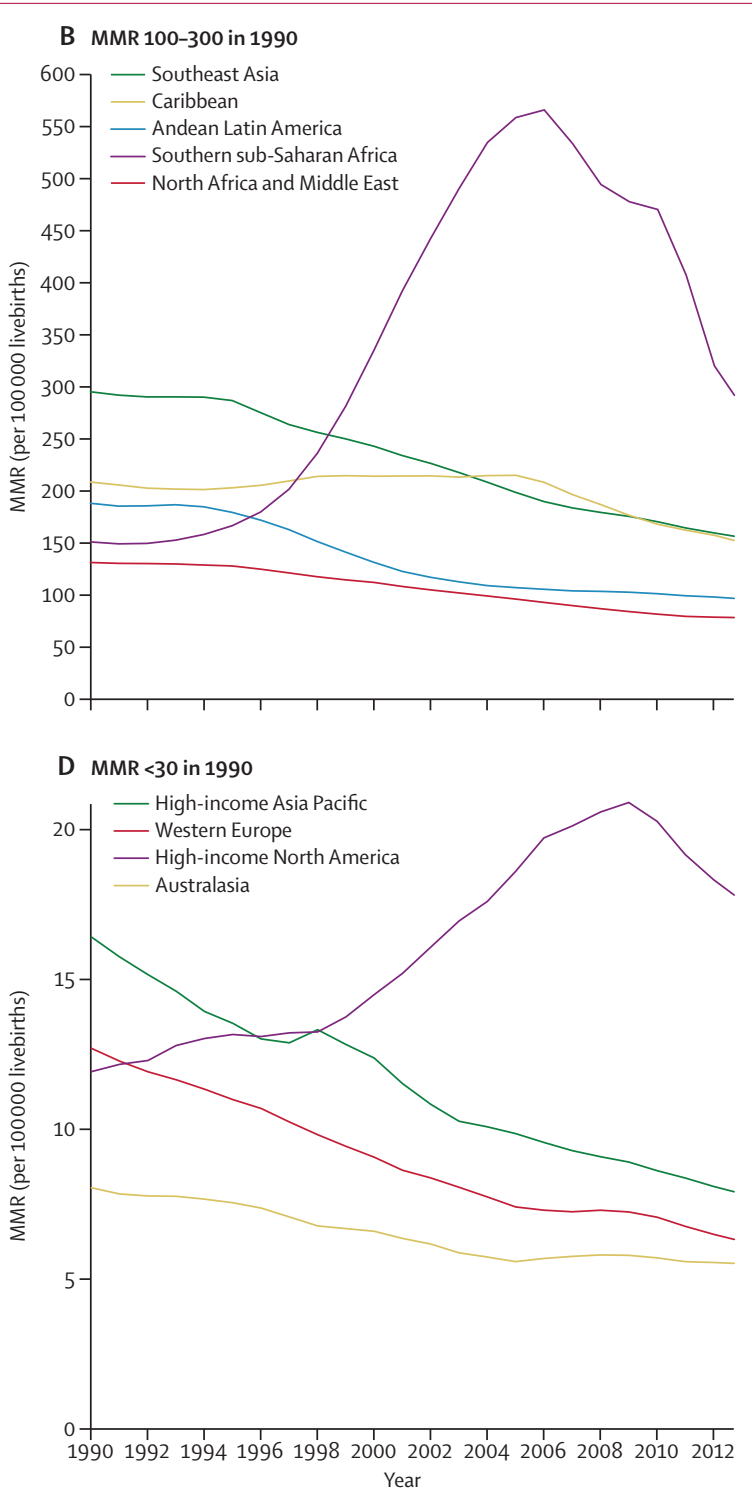
2013, although different trends are apparent in different regions. For example, east Asia had significant decreases in all causes except HIV (which was estimated to be the cause of $0.003 \%$ of all maternal deaths in 2013; appendix). The total global number of HIV-related maternal deaths in 2013 was 2070 (95\% UI 1290-2866), reduced from a peak of 3280 (2041-4403) in 2004. The increase in proportion of deaths due to indirect maternal causes was most notable in Latin America and the Caribbean, where the proportion increased from $9.2 \%(95 \%$ UI $8 \cdot 8-9.8)$ in 1990 , to $11.5 \%$ $(10 \cdot 9-12 \cdot 2)$ in 2013

In 2013 , on average, nearly a quarter of deaths occurred antepartum $(24 \cdot 6 \%, 24 \cdot 1-25 \cdot 2)$, a quarter intrapartum and immediately postpartum $(27 \cdot 7 \%, 27 \cdot 1-28 \cdot 2)$, a third 
subacute and delayed postpartum $(35 \cdot 6 \%, 34 \cdot 9-36 \cdot 2)$, and $12 \cdot 1 \%(11 \cdot 9-12 \cdot 5)$ late. The biggest absolute change was in intrapartum deaths (table 2, appendix), which decreased by more than $35 \%$, but equally notable was that despite a decrease in the mean fraction of postpartum deaths, the proportion of total deaths occurring postpartum and late actually increased at the global level $(\mathrm{p}<0 \cdot 001)$.
SVillalpando PhD, Prof R Lozano) Department of Diabetes Research, National Centre fo Global Health and Medicine, Tokyo, Japan (A Goto PhD);

\begin{tabular}{|c|c|c|c|c|c|c|c|c|c|c|c|c|c|}
\hline & \multicolumn{9}{|c|}{ Cause of death } & \multicolumn{4}{|c|}{ Timing of death } \\
\hline & Abortion & $\begin{array}{l}\text { Haem- } \\
\text { orrhage }\end{array}$ & $\begin{array}{l}\text { Hyper- } \\
\text { tension }\end{array}$ & $\begin{array}{l}\text { Obstructed } \\
\text { labour }\end{array}$ & Sepsis & Late & $\begin{array}{l}\text { Other } \\
\text { direct }\end{array}$ & Indirect & HIV & $\begin{array}{l}\text { Ante- } \\
\text { partum }\end{array}$ & $\begin{array}{l}\text { Intra- } \\
\text { partum* }\end{array}$ & Postpartum $†$ & Late \\
\hline Worldwide & $\begin{array}{l}43684 \\
(38336- \\
49843)\end{array}$ & $\begin{array}{l}44190 \\
(38275- \\
50819)\end{array}$ & $\begin{array}{l}29275 \\
(25664- \\
33376)\end{array}$ & $\begin{array}{l}18789 \\
(16281- \\
21747)\end{array}$ & $\begin{array}{l}23717 \\
(20045- \\
27993)\end{array}$ & $\begin{array}{l}43507 \\
(35667- \\
52395)\end{array}$ & $\begin{array}{l}56114 \\
(48671- \\
64245)\end{array}$ & $\begin{array}{l}31058 \\
(26818- \\
35679)\end{array}$ & $\begin{array}{l}2070 \\
(1290- \\
2866)\end{array}$ & $\begin{array}{l}61176 \\
(52959- \\
70010)\end{array}$ & $\begin{array}{l}64823 \\
(55562- \\
74856)\end{array}$ & $\begin{array}{l}123476 \\
(109051- \\
139584)\end{array}$ & $\begin{array}{l}43507 \\
(35667- \\
52395)\end{array}$ \\
\hline $\begin{array}{l}\text { Andean } \\
\text { Latin America }\end{array}$ & $\begin{array}{c}160 \\
(115-215)\end{array}$ & $\begin{array}{c}165 \\
(126-211)\end{array}$ & $\begin{array}{c}174 \\
(131-217)\end{array}$ & $\begin{array}{c}64 \\
(46-84)\end{array}$ & $\begin{array}{c}128 \\
(98-163)\end{array}$ & $\begin{array}{c}260 \\
(194-331)\end{array}$ & $\begin{array}{c}125 \\
(95-158)\end{array}$ & $\begin{array}{c}85 \\
(65-109)\end{array}$ & $\begin{array}{r}0 \\
(0-0)\end{array}$ & $\begin{array}{c}154 \\
(114-204)\end{array}$ & $\begin{array}{c}285 \\
(210-370)\end{array}$ & $\begin{array}{c}465 \\
(348-590)\end{array}$ & $\begin{array}{c}260 \\
(194-331)\end{array}$ \\
\hline Australasia & $(2-3)^{2}$ & $(2-3)^{2}$ & $(2-4)^{3}$ & $(2-3)^{2}$ & $(1-2)^{2}$ & $(1-2)^{2}$ & $(4-6)^{5}$ & $(2-4)^{3}$ & $\begin{array}{r}0 \\
(0-0)\end{array}$ & $(4-8)^{6}$ & $(5-8)^{6}$ & $(5-9)^{7}$ & $(1-2)^{2}$ \\
\hline Caribbean & $\begin{array}{c}132 \\
(83-195)\end{array}$ & $\begin{array}{c}146 \\
(90-228)\end{array}$ & $\begin{array}{c}284 \\
(198-415)\end{array}$ & $\begin{array}{c}73 \\
(43-111)\end{array}$ & $\begin{array}{c}119 \\
(80-175)\end{array}$ & $\begin{array}{c}92 \\
(50-146)\end{array}$ & $\begin{array}{c}129 \\
(81-194)\end{array}$ & $\begin{array}{c}90 \\
(53-140)\end{array}$ & $\begin{array}{c}7 \\
(4-11)\end{array}$ & $\begin{array}{c}272 \\
(168-419)\end{array}$ & $\begin{array}{c}300 \\
(163-480)\end{array}$ & $\begin{array}{c}410 \\
(276-612)\end{array}$ & $\begin{array}{c}92 \\
(50-146)\end{array}$ \\
\hline Central Asia & $\begin{array}{r}58 \\
(47-72)\end{array}$ & $\begin{array}{c}84 \\
(69-100)\end{array}$ & $\begin{array}{c}55 \\
(45-67)\end{array}$ & $\begin{array}{r}52 \\
(41-67)\end{array}$ & $\begin{array}{c}64 \\
(50-80)\end{array}$ & $\begin{array}{c}81 \\
(66-100)\end{array}$ & $\begin{array}{c}107 \\
(86-133)\end{array}$ & $\begin{array}{c}67 \\
(55-83)\end{array}$ & $\begin{array}{r}0 \\
(0-0)\end{array}$ & $\begin{array}{c}174 \\
(139-215)\end{array}$ & $\begin{array}{c}114 \\
(92-141)\end{array}$ & $\begin{array}{c}199 \\
(164-242)\end{array}$ & $\begin{array}{c}81 \\
(66-100)\end{array}$ \\
\hline Central Europe & $\begin{array}{c}24 \\
(20-28)\end{array}$ & $\begin{array}{r}15 \\
(12-18)\end{array}$ & $\begin{array}{c}12 \\
(10-14)\end{array}$ & $\begin{array}{r}11 \\
(9-14)\end{array}$ & $\begin{array}{r}9 \\
(7-11)\end{array}$ & $\begin{array}{r}11 \\
(8-13)\end{array}$ & $\begin{array}{c}17 \\
(14-20)\end{array}$ & $\begin{array}{c}13 \\
(10-16)\end{array}$ & $\begin{array}{r}0 \\
(0-0)\end{array}$ & $\begin{array}{c}24 \\
(19-27)\end{array}$ & $\begin{array}{c}40 \\
(33-48)\end{array}$ & $\begin{array}{r}38 \\
(31-45)\end{array}$ & $\begin{array}{r}11 \\
(8-13)\end{array}$ \\
\hline $\begin{array}{l}\text { Central Latin } \\
\text { America }\end{array}$ & $\begin{array}{c}331 \\
(294-376)\end{array}$ & $\begin{array}{c}478 \\
(426-537)\end{array}$ & $\begin{array}{c}563 \\
(495-635)\end{array}$ & $\begin{array}{c}196 \\
(173-223)\end{array}$ & $\begin{array}{c}227 \\
(198-261)\end{array}$ & $\begin{array}{c}215 \\
(177-251)\end{array}$ & $\begin{array}{c}446 \\
(394-505)\end{array}$ & $\begin{array}{c}486 \\
(428-546)\end{array}$ & $\begin{array}{r}1 \\
(1-2)\end{array}$ & $\begin{array}{c}513 \\
(392-672)\end{array}$ & $\begin{array}{c}1112 \\
(917-1347)\end{array}$ & $\begin{array}{c}1110 \\
(858-1354)\end{array}$ & $\begin{array}{c}215 \\
(177-251)\end{array}$ \\
\hline $\begin{array}{l}\text { Central sub- } \\
\text { Saharan Africa }\end{array}$ & $\begin{array}{c}2679 \\
(2031- \\
3491)\end{array}$ & $\begin{array}{c}2233 \\
(1663- \\
3018)\end{array}$ & $\begin{array}{l}1645 \\
(1215- \\
2197)\end{array}$ & $\begin{array}{c}863 \\
(652- \\
1106)\end{array}$ & $\begin{array}{l}1386 \\
(1010- \\
1870)\end{array}$ & $\begin{array}{r}2350 \\
(1664- \\
3154)\end{array}$ & $\begin{array}{l}2831 \\
(2078- \\
3712)\end{array}$ & $\begin{array}{l}1222 \\
(823- \\
1629)\end{array}$ & $\begin{array}{c}114 \\
(62- \\
167)\end{array}$ & $\begin{array}{l}4805 \\
(3654- \\
6210)\end{array}$ & $\begin{array}{l}1298 \\
(815- \\
1876)\end{array}$ & $\begin{array}{l}6902 \\
(5184- \\
8723)\end{array}$ & $\begin{array}{l}2350 \\
(1664- \\
3154)\end{array}$ \\
\hline East Asia & $\begin{array}{c}395 \\
(324-467)\end{array}$ & $\begin{array}{c}709 \\
(578-854)\end{array}$ & $\begin{array}{c}322 \\
(260-385)\end{array}$ & $\begin{array}{c}365 \\
(292-443)\end{array}$ & $\begin{array}{c}298 \\
(246-356)\end{array}$ & $\begin{array}{c}376 \\
(305-458)\end{array}$ & $\begin{array}{c}545 \\
(446-643)\end{array}$ & $\begin{array}{c}518 \\
(414-614)\end{array}$ & $\begin{array}{r}0 \\
(0-0)\end{array}$ & $\begin{array}{c}725 \\
(503-976)\end{array}$ & $\begin{array}{c}1780 \\
(1369-2213)\end{array}$ & $\begin{array}{c}654 \\
(439-899)\end{array}$ & $\begin{array}{c}376 \\
(305-458)\end{array}$ \\
\hline Eastern Europe & $\begin{array}{c}66 \\
(54-80)\end{array}$ & $\begin{array}{c}50 \\
(39-60)\end{array}$ & $\begin{array}{c}34 \\
(26-42)\end{array}$ & $\begin{array}{c}46 \\
(34-60)\end{array}$ & $\begin{array}{c}26 \\
(20-33)\end{array}$ & $\begin{array}{r}39 \\
(27-53)\end{array}$ & $\begin{array}{c}93 \\
(75-112)\end{array}$ & $\begin{array}{c}78 \\
(62-95)\end{array}$ & $\begin{array}{r}0 \\
(0-0)\end{array}$ & $\begin{array}{c}192 \\
(150-235)\end{array}$ & $\begin{array}{c}44 \\
(28-63)\end{array}$ & $\begin{array}{c}159 \\
(127-195)\end{array}$ & $\begin{array}{c}39 \\
(27-53)\end{array}$ \\
\hline $\begin{array}{l}\text { Eastern sub- } \\
\text { Saharan Africa }\end{array}$ & $\begin{array}{c}10142 \\
(8413- \\
12152)\end{array}$ & $\begin{array}{c}6276 \\
(5228- \\
7707)\end{array}$ & $\begin{array}{l}5286 \\
(4327- \\
6467)\end{array}$ & $\begin{array}{l}2718 \\
(2248- \\
3261)\end{array}$ & $\begin{array}{c}4908 \\
(3967- \\
5996)\end{array}$ & $\begin{array}{c}4702 \\
(3732- \\
5807)\end{array}$ & $\begin{array}{c}13312 \\
(11350- \\
15591)\end{array}$ & $\begin{array}{l}3976 \\
(3237- \\
5126)\end{array}$ & $\begin{array}{c}844 \\
(524- \\
1144)\end{array}$ & $\begin{array}{l}13429 \\
(11038- \\
16452)\end{array}$ & $\begin{array}{c}9176 \\
(7334- \\
11319)\end{array}$ & $\begin{array}{c}24962 \\
(20629- \\
30208)\end{array}$ & $\begin{array}{c}4702 \\
(3732- \\
5807)\end{array}$ \\
\hline $\begin{array}{l}\text { High-income } \\
\text { Asia Pacific }\end{array}$ & $\begin{array}{r}17 \\
(13-22)\end{array}$ & $\begin{array}{r}22 \\
(17-29)\end{array}$ & $\begin{array}{r}12 \\
(9-17)\end{array}$ & $\begin{array}{r}10 \\
(7-13)\end{array}$ & $\begin{array}{r}13 \\
(9-18)\end{array}$ & $\begin{array}{r}7 \\
(5-10)\end{array}$ & $\begin{array}{r}26 \\
(20-35)\end{array}$ & $\begin{array}{c}21 \\
(16-27)\end{array}$ & $\begin{array}{r}0 \\
(0-0)\end{array}$ & $\begin{array}{c}51 \\
(37-68)\end{array}$ & $\begin{array}{c}33 \\
(24-48)\end{array}$ & $\begin{array}{r}37 \\
(24-50)\end{array}$ & $\begin{array}{r}7 \\
(5-10)\end{array}$ \\
\hline $\begin{array}{l}\text { High-income } \\
\text { North America }\end{array}$ & $\begin{array}{c}97 \\
(76-122)\end{array}$ & $\begin{array}{r}44 \\
(33-57)\end{array}$ & $\begin{array}{c}64 \\
(48-83)\end{array}$ & $\begin{array}{r}51 \\
(31-78)\end{array}$ & $\begin{array}{c}63 \\
(49-78)\end{array}$ & $\begin{array}{c}143 \\
(112-178)\end{array}$ & $\begin{array}{c}224 \\
(176-280)\end{array}$ & $\begin{array}{c}143 \\
(112-178)\end{array}$ & $\begin{array}{r}0 \\
(0-0)\end{array}$ & $\begin{array}{c}120 \\
(72-176)\end{array}$ & $\begin{array}{c}254 \\
(180-341)\end{array}$ & $\begin{array}{c}313 \\
(224-411)\end{array}$ & $\begin{array}{c}143 \\
(112-178)\end{array}$ \\
\hline $\begin{array}{l}\text { North Africa } \\
\text { and Middle East }\end{array}$ & $\begin{array}{c}1130 \\
(843- \\
1500)\end{array}$ & $\begin{array}{l}1831 \\
(1421- \\
2415)\end{array}$ & $\begin{array}{l}1294 \\
(1008- \\
1713)\end{array}$ & $\begin{array}{c}838 \\
(632- \\
1095)\end{array}$ & $\begin{array}{c}809 \\
(610- \\
1084)\end{array}$ & $\begin{array}{c}836 \\
(556- \\
1206)\end{array}$ & $\begin{array}{l}1300 \\
(996- \\
1741)\end{array}$ & $\begin{array}{c}847 \\
(616- \\
1171)\end{array}$ & $\begin{array}{r}3 \\
(2-5)\end{array}$ & $\begin{array}{l}2129 \\
(1620- \\
2907)\end{array}$ & $\begin{array}{l}2692 \\
(1950- \\
3638)\end{array}$ & $\begin{array}{l}3249 \\
(2384- \\
4402)\end{array}$ & $\begin{array}{l}836 \\
(556- \\
1206)\end{array}$ \\
\hline Oceania & $\begin{array}{c}212 \\
(108-363)\end{array}$ & $\begin{array}{c}244 \\
(123-437)\end{array}$ & $\begin{array}{c}136 \\
(68-249)\end{array}$ & $\begin{array}{c}117 \\
(59-203)\end{array}$ & $\begin{array}{c}102 \\
(53-185)\end{array}$ & $\begin{array}{c}180 \\
(92-335)\end{array}$ & $\begin{array}{c}212 \\
(111-379)\end{array}$ & $\begin{array}{c}116 \\
(58-205)\end{array}$ & $\begin{array}{r}2 \\
(1-3)\end{array}$ & $\begin{array}{c}297 \\
(151-543)\end{array}$ & $\begin{array}{c}583 \\
(308-1035)\end{array}$ & $\begin{array}{c}264 \\
(129-484)\end{array}$ & $\begin{array}{c}180 \\
(92-335)\end{array}$ \\
\hline South Asia & $\begin{array}{c}12074 \\
(9081- \\
15883)\end{array}$ & $\begin{array}{l}16453 \\
(11957- \\
22330)\end{array}$ & $\begin{array}{l}10656 \\
(7805- \\
14072)\end{array}$ & $\begin{array}{c}7099 \\
(5425- \\
9206)\end{array}$ & $\begin{array}{c}9382 \\
(6734- \\
12841)\end{array}$ & $\begin{array}{l}19900 \\
(14138- \\
27257)\end{array}$ & $\begin{array}{l}19433 \\
(14257- \\
26136)\end{array}$ & $\begin{array}{l}12601 \\
(9303- \\
16472)\end{array}$ & $\begin{array}{c}26 \\
(13-43)\end{array}$ & $\begin{array}{l}21202 \\
\left(15555^{-}\right. \\
27811)\end{array}$ & $\begin{array}{l}23518 \\
(17274- \\
30621)\end{array}$ & $\begin{array}{c}43207 \\
(32787- \\
55636)\end{array}$ & $\begin{array}{l}19900 \\
(14138- \\
27257)\end{array}$ \\
\hline Southeast Asia & $\begin{array}{c}2638 \\
(1964- \\
3459)\end{array}$ & $\begin{array}{c}2656 \\
(1968- \\
3460)\end{array}$ & $\begin{array}{l}2388 \\
(1718- \\
3144)\end{array}$ & $\begin{array}{l}1346 \\
(941- \\
1855)\end{array}$ & $\begin{array}{l}1460 \\
(1044- \\
1935)\end{array}$ & $\begin{array}{l}2274 \\
(1672- \\
3009)\end{array}$ & $\begin{array}{l}3217 \\
(2348- \\
4232)\end{array}$ & $\begin{array}{l}2001 \\
(1498- \\
2654)\end{array}$ & $\begin{array}{c}9 \\
(5-14)\end{array}$ & $\begin{array}{c}4007 \\
(2980- \\
5262)\end{array}$ & $\begin{array}{r}8039 \\
(6154- \\
10319)\end{array}$ & $\begin{array}{l}3708 \\
(2836- \\
4927)\end{array}$ & $\begin{array}{l}2274 \\
(1672- \\
3009)\end{array}$ \\
\hline $\begin{array}{l}\text { Southern } \\
\text { Latin America }\end{array}$ & $\begin{array}{c}94 \\
(77-115)\end{array}$ & $\begin{array}{r}44 \\
(35-54)\end{array}$ & $\begin{array}{c}45 \\
(36-56)\end{array}$ & $\begin{array}{r}28 \\
(20-37)\end{array}$ & $\begin{array}{c}73 \\
(59-88)\end{array}$ & $\begin{array}{c}29 \\
(22-36)\end{array}$ & $\begin{array}{r}51 \\
(41-61)\end{array}$ & $\begin{array}{c}80 \\
(66-98)\end{array}$ & $\begin{array}{r}0 \\
(0-1)\end{array}$ & $\begin{array}{c}196 \\
(151-246)\end{array}$ & $\begin{array}{c}107 \\
(73-150)\end{array}$ & $\begin{array}{c}114 \\
(69-158)\end{array}$ & $\begin{array}{c}29 \\
(22-36)\end{array}$ \\
\hline $\begin{array}{l}\text { Southern sub- } \\
\text { Saharan Africa }\end{array}$ & $\begin{array}{c}718 \\
(488-1026)\end{array}$ & $\begin{array}{c}517 \\
(360-714)\end{array}$ & $\begin{array}{c}624 \\
(428-868)\end{array}$ & $\begin{array}{c}298 \\
(197-437)\end{array}$ & $\begin{array}{c}627 \\
(430-914)\end{array}$ & $\begin{array}{c}604 \\
(376-914)\end{array}$ & $\begin{array}{c}463 \\
(313-662)\end{array}$ & $\begin{array}{c}657 \\
(435-942)\end{array}$ & $\begin{array}{c}381 \\
(217-563)\end{array}$ & $\begin{array}{l}1059 \\
(660-1542)\end{array}$ & $\begin{array}{c}1014 \\
(571-1662)\end{array}$ & $\begin{array}{c}2221 \\
(1471-3256)\end{array}$ & $\begin{array}{c}604 \\
(376-914)\end{array}$ \\
\hline $\begin{array}{l}\text { Tropical } \\
\text { Latin America }\end{array}$ & $\begin{array}{c}225 \\
(171-287)\end{array}$ & $\begin{array}{c}196 \\
(147-253)\end{array}$ & $\begin{array}{c}341 \\
(259-435)\end{array}$ & $\begin{array}{r}69 \\
(51-92)\end{array}$ & $\begin{array}{c}249 \\
(192-317)\end{array}$ & $\begin{array}{c}272 \\
(178-378)\end{array}$ & $\begin{array}{c}279 \\
(214-356)\end{array}$ & $\begin{array}{c}332 \\
(253-426)\end{array}$ & $\begin{array}{r}1 \\
(1-2)\end{array}$ & $\begin{array}{c}295 \\
(191-418)\end{array}$ & $\begin{array}{c}544 \\
(349-776)\end{array}$ & $\begin{array}{c}858 \\
(623-1158)\end{array}$ & $\begin{array}{c}272 \\
(178-378)\end{array}$ \\
\hline Western Europe & $\begin{array}{r}55 \\
(45-62)\end{array}$ & $\begin{array}{r}35 \\
(29-41)\end{array}$ & $\begin{array}{c}34 \\
(28-39)\end{array}$ & $\begin{array}{r}23 \\
(19-27)\end{array}$ & $\begin{array}{c}24 \\
(20-29)\end{array}$ & $\begin{array}{c}23 \\
(18-28)\end{array}$ & $\begin{array}{c}60 \\
(50-68)\end{array}$ & $\begin{array}{c}34 \\
(28-40)\end{array}$ & $\begin{array}{r}0 \\
(0-0)\end{array}$ & $\begin{array}{c}65 \\
(52-78)\end{array}$ & $\begin{array}{c}89 \\
(74-104)\end{array}$ & $\begin{array}{r}112 \\
(92-132)\end{array}$ & $\begin{array}{c}23 \\
(18-28)\end{array}$ \\
\hline $\begin{array}{l}\text { Western sub- } \\
\text { Saharan Africa }\end{array}$ & $\begin{array}{l}12436 \\
(10015- \\
15401)\end{array}$ & $\begin{array}{l}11990 \\
(9449- \\
15320)\end{array}$ & $\begin{array}{c}5301 \\
(4139- \\
6773)\end{array}$ & $\begin{array}{c}4521 \\
(3382- \\
5992)\end{array}$ & $\begin{array}{c}3749 \\
(2745- \\
4945)\end{array}$ & $\begin{array}{c}11114 \\
(8229- \\
14535)\end{array}$ & $\begin{array}{l}13239 \\
(10539- \\
16609)\end{array}$ & $\begin{array}{c}7687 \\
(5894- \\
9976)\end{array}$ & $\begin{array}{c}680 \\
(372- \\
1039)\end{array}$ & $\begin{array}{l}11460 \\
(8923- \\
14807)\end{array}$ & $\begin{array}{l}13795 \\
(10460- \\
18323)\end{array}$ & $\begin{array}{c}34489 \\
(27764- \\
42248)\end{array}$ & $\begin{array}{l}11114 \\
(8229- \\
14535)\end{array}$ \\
\hline
\end{tabular}


School of Population Health (D G Hoy PhD), University of Queensland, Brisbane, QLD, Australia (H N Gouda PhD, L Knibbs PhD); Saint James School of Medicine, Kralendijk, Bonaire, Netherlands (Prof HC Gugnani PhD); Kanawha Charleston Health Department, Charleston, WV, USA (Rahul Gupta MD); Fortis Escorts Hospital, Jaipur, India (Rajeev Gupta PhD); Arabian Gulf University, Manama, Bahrain (Prof R R Hamadeh DPhil); Wayne

County Department of Health and Human Services, Detroit, $\mathrm{MI}_{\iota}$ USA (M Hammami MD); School of Medicine and Pharmacology, University of Western Australia, Perth, WA, Australia (Prof GJ Hankey MD); Parnassia Psychiatric Institute, The Hague,

Netherlands (HW Hoek MD); Albert Einstein College of Medicine, Bronx, NY, USA (Prof H D Hosgood PhD); Public Health Division, Secretariat of the Pacific Community, Noumea, New Caledonia (D G Hoy); Birzeit University, Birzeit, Ramallah,

Palestine (A Husseini PhD);

National Institute for Health Development, Tallinn, Estonia ( $\mathrm{Innos} \mathrm{PhD}$, M Leinsalu PhD); School of Public Health (Prof N Kawakami MD), Graduate School of Medicine

(M Inoue PhD), University of Tokyo, Tokyo, Japan

(Prof K Shibuya MD); George Mason University, Fairfax, VA, USA (K H Jacobsen PhD); Ochsner Medical Centre, New Orleans, LA USA (E Jahangir MD); Graduate School of Public Health, Yonsei University, Seoul, South Korea (Prof S H Jee PhD); Postgraduate Institute of Medical Education and Research, Chandigarh, India (ProfV Jha DM); Tianjin Centres

for Diseases Control and

Prevention, Tianjin, China (G Jiang MD); Department of Ophthalmology, Medical Faculty Mannheim, University of Heidelberg, Heidelberg, Germany (Prof J B Jonas MD); National Institute of Public Health, Copenhagen, Denmark (Prof KJuel PhD); Vanderbilt University, Nashville, TN, USA (E K Kabagambe PhD, U Sampson MD); Fudan University, Shanghai, China

(H Kan MD); University of Balamand, Beirut, Lebanon (N E Karam MD); Helmholtz Centre for Infection Research, Braunschweig, Germany (A Karch MD); Malaria and Other

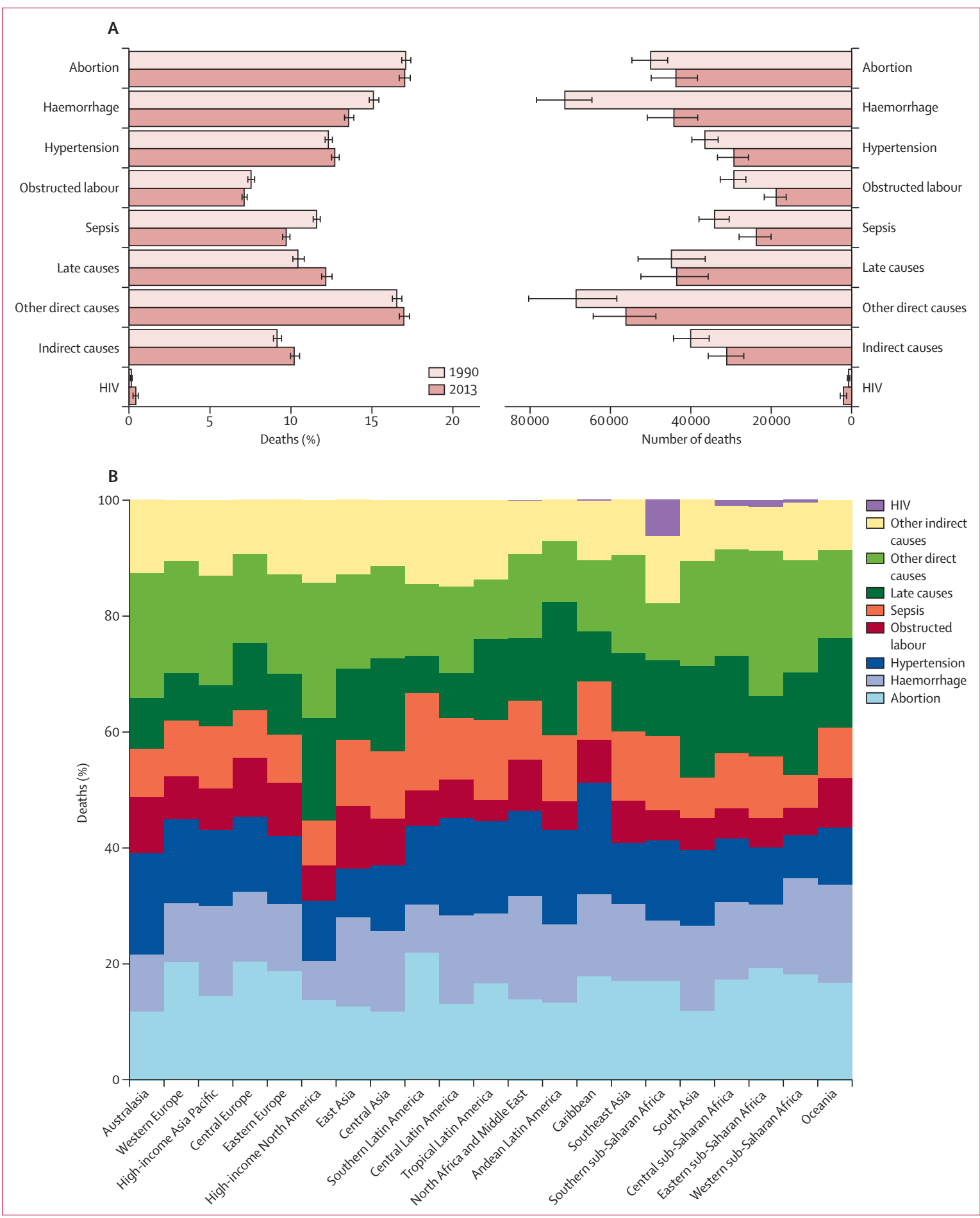

Figure 6: Causes of maternal death

(A) Mean proportion (left) and total number (right) of maternal deaths due to different causes in 1990 and 2013 . Error bars show $95 \%$ uncertainty intervals.

(B) Proportion of maternal deaths due to different causes in 2013, by region.

In 2013, 16 countries had MMRs of between 500 and 1000: Afghanistan, Cameroon, Central African Republic, Chad, Côte d'Ivoire, Djibouti, Eritrea, Guinea, Guinea-
Bissau, Liberia, Lesotho, Mauritania, Papua New Guinea, Sierra Leone, South Sudan, and Zimbabwe (figure 7, table 1). 15 countries had MMRs of less than 5: Andorra, 


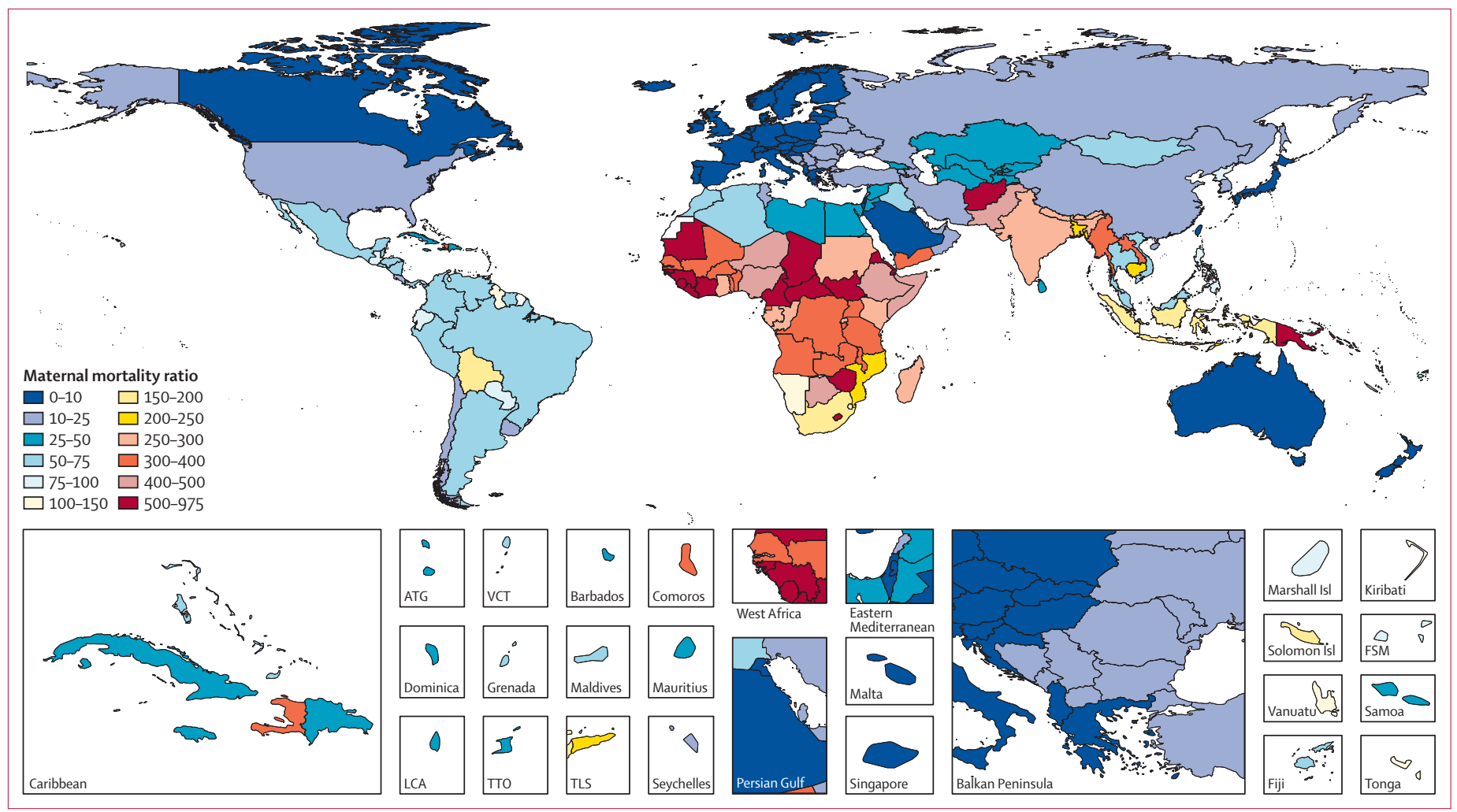

Figure 7: Maternal mortality ratio in 2013

ATG=Antigua and Barbuda. VCT=Saint Vincent and the Grenadines. Isl=Islands. FSM=Federated States of Micronesia. LCA=Saint Lucia. TTO=Trinidad and Tobago. TLS=Timor-Leste.

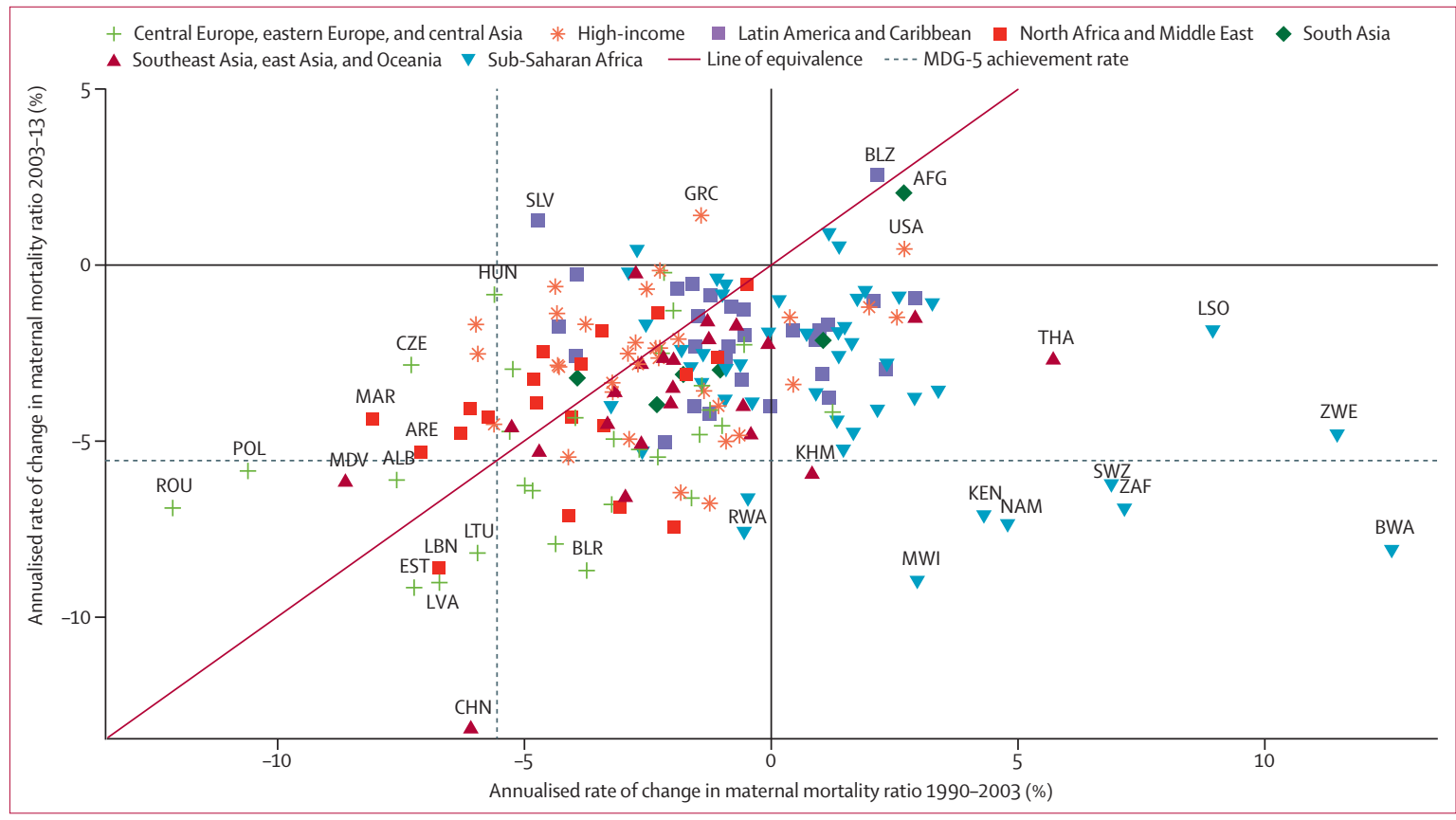

Figure 8: Annualised rate of change in maternal mortality ratio in 1990-2003 and 2003-13

Countries are grouped by Global Burden of Disease super-region. Countries are labelled when at or near the MDG5 achievement rate, or if they had large increases in either period. MDG=Millennium Development Goal. ROU=Romania. POL=Poland. MDV=Maldives. MAR=Morocco. ALB=Albania. CZE=Czech Republic. ARE=United Arab Emirates. EST=Estonia. LBN=Lebanon. LVA=Latvia. CHN=China. $L T U=L i t h u a n i a . ~ H U N=H u n g a r y . ~ S L V=E l$ Salvador. BLR=Belarus. GRC=Greece. RWA=Rwanda. KHM=Cambodia. BLZ=Belize. AFG=Afghanistan. MWI=Malawi. KEN=Kenya. NAM=Namibia. THA=Thailand. SWZ=Swaziland. ZAF=South Africa. LSO=Lesotho. ZWE=Zimbabwe. BWA=Botswana.

Parasitic Diseases Division (CK Karema MSc), Ministry of Health, Kigali, Rwanda (F Sayinzoga MD); Oklahoma State University, Tulsa, OK, USA (A Kaul MD); University of California San Francisco, San Francisco, CA, USA (D S Kazi MD); University of São Paulo, São Paulo, Brazil (Prof A H Kemp PhD Prof PA Lotufo DrPH, ProfGV Polanczyk PhD, Prof IS Santos PhD); South African Medical Research Council, Cape Town, South Africa (A P Kengne PhD); Jordan University of Science and Technology, Al-Ramtha, Jordan (ProfY S Khader SCD); Supreme Council of Health, Doha, Qatar (SEA H Khalifa MSc); Health Services Academy, Islamabad, Pakistan (EA Khan MPH); Institute of Health Policy and Management, Seoul National University College of Medicine, Seoul, South Korea (ProfY-H Khang PhD); Department of Preventive Cardiology, Department of Preventive Medicine and Epidemiologic Informatics, National Cerebral and 
Cardiovascular Centre, Suita, Japan (Y Kokubo PhD); Centre for Community Empowerment, Health Policy and Humanities, National Institute of Health Research and Development, Jakarta, Indonesia (S Kosen MD); University of Montreal, Montreal, OC, Canada (Prof B Kuate Defo PhD); Rajrajeshwari Medical College and Hospital, Bangalore, India (ProfC Kulkarni PhD); Arkansas State University, Jonesboro, AR, USA (V S Kulkarni PhD); International Institute for Population Sciences, Mumbai, India (K Kumar MPS); Indian Institute of Public Health, Public Health Foundation of India, Gurgaon, India (R B Kumar); Boston Medical Centre, Boston,

MA, USA (G Kwan MD); Fourth View Consulting, Tallinn, Estonia (T Lai PhD); Australian Research

Centre for Population Oral Health (ARCPOH), School of Dentistry, University of Adelaide, Adelaide, SA, Australia (Prof R Lalloo PhD); Institute of Health Policy and Development Studies, National Institutes of

Health, Manila, Philippines (Prof H Lam PhD); International
Australia, Austria, Denmark, Finland, Iceland, Ireland, Israel, Italy, Malta, Norway, Poland, Singapore, Sweden, and Switzerland (table 1). Some countries had noticeably higher MMRs than neighbouring countries did (figure 7). In the Caribbean, only Guyana and Haiti had MMRs of more than 100 in 2013 (figure 7, table 1). Similarly, in South America, only Bolivia had an MMR of more than 100 (figure 7, table 1). Afghanistan had the highest MMR in south Asia, Yemen had the highest MMR in north Africa and the Middle East, and Papua New Guinea had the largest value in southeast Asia and Oceania in 2013 (figure 7, table 1). The MMR in China was $17 \cdot 2(95 \%$ UI $14 \cdot 0-20 \cdot 3)$ compared with $18 \cdot 5$ (14.8-22.9) in the USA. In sub-Saharan Africa, Mauritius, Seychelles, Namibia, Swaziland, Cape Verde, and São Tomé and Príncipe have MMRs of less than 150 (figure 7, table 1).

137 countries had higher annualised rates of change in MMR between 2003 and 2013 than between 1990 and 2003 (figure 8). Nevertheless, only 40 countries have achieved the MDG 5 decrease of $5 \cdot 5 \%$ per year in either time interval (figure 8). From 1990 to 2013, Albania, United Arab Emirates, Bosnia and Herzegovina, Belarus, China, Estonia, Lebanon, Lithuania, Latvia, Morocco, Maldives, Mongolia, Oman, Poland, Romania, and Russia had reductions of greater than $5 \cdot 5 \%$ (table 1 ). These countries-which represent $5 \cdot 1 \%$ of all developing nations-are likely to achieve the MDG 5 target of a reduction in the MMR of three-quarters. 30 countries had annual reductions in the MMR of MDG 5 pace or better from 2003 to 2013, eight of which were in subSaharan Africa (Botswana, Burundi, Kenya, Malawi, Namibia, Rwanda, South Africa, and Swaziland) and ten in central and eastern Europe (Albania, Belarus, Bosnia and Herzegovina, Bulgaria, Estonia, Latvia, Lithuania, Poland, Romania, and Russia; table 1). Between 2003 and 2013, eight countries had annualised rates of change of more than 8\%: Belarus, Botswana, China, Estonia, Latvia, Lebanon, Lithuania, and Malawi (figure 8, table 1). From 1990 to 2003, MMR increased in 50 countries, 27 of which were in sub-Saharan Africa (table 1). Between 2003 and 2013, only eight countries had increases: Afghanistan, Belize, El Salvador, Guinea-Bissau, Greece, Seychelles, South Sudan, and the USA (figure 8, table 1).

In our fairly optimistic forecast scenario for 2030, we would expect 184100 (95\% UI 133600-244700) maternal deaths worldwide in 2030. 53 countries-all of which are in sub-Saharan Africa, except for Afghanistan, Bangladesh, Bhutan, Bolivia, Haiti, India, Indonesia Laos, Myanmar, Nepal, Pakistan, Papua New Guinea Solomon Islands, and Yemen-will still have MMRs of more than 100 (figure 9). Despite accelerated reductions in many countries, our simple forecasts suggest that in 2030, 74 countries are likely to still have a MMR of more

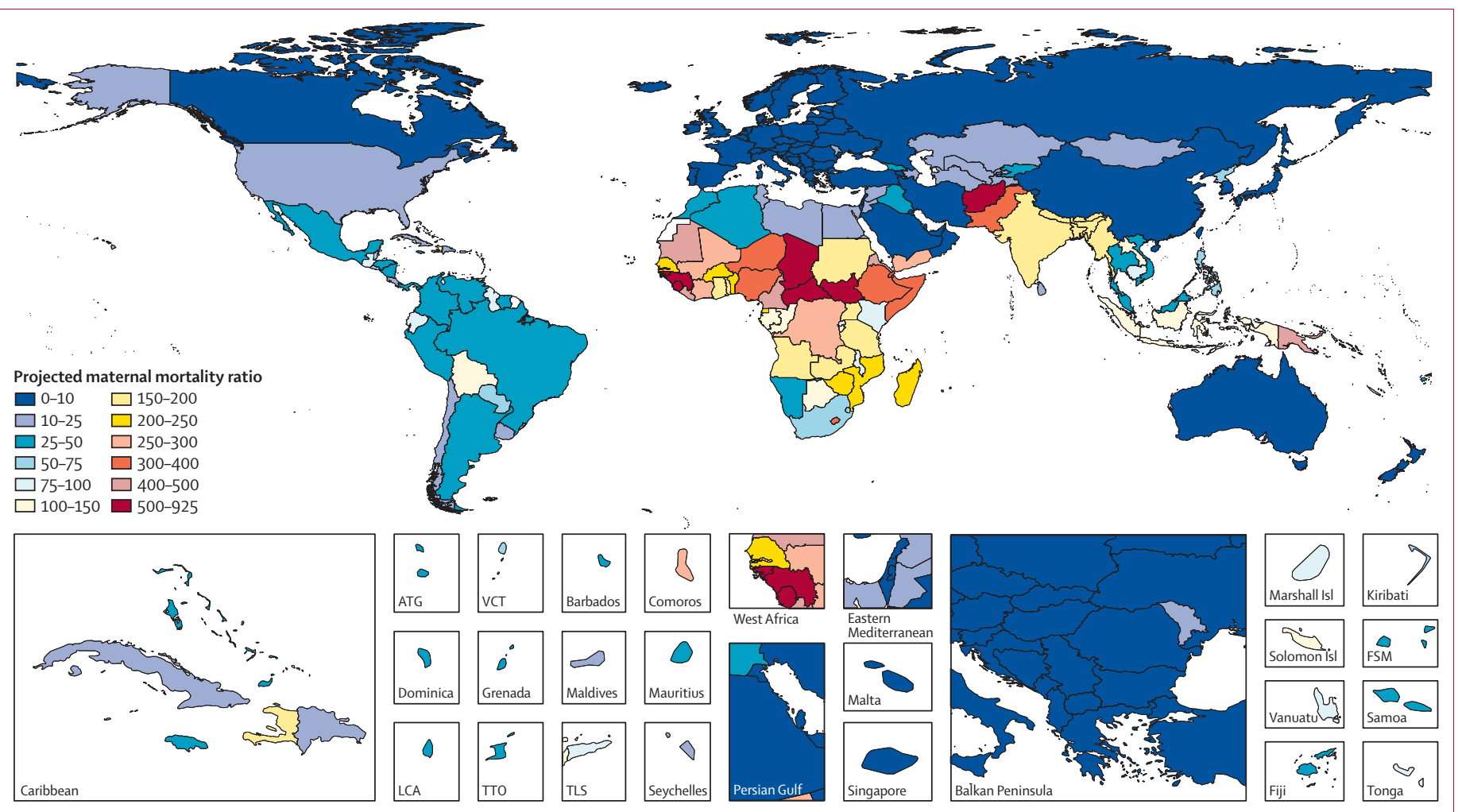

Figure 9: Projected maternal mortality ratio in 2030

ATG=Antigua and Barbuda. VCT=Saint Vincent and the Grenadines. IsI=Islands. FSM=Federated States of Micronesia. LCA=Saint Lucia. TTO=Trinidad and Tobago. TLS=Timor-Leste. 
than 50, and 89 countries will have MMRs of less than 30 , compared with 72 countries in 2013.

\section{Discussion}

On the basis of recent data and a refined understanding of the association between HIV and maternal mortality, we have shown that worldwide maternal mortality has decreased by $1.3 \%$ per year since 1990 . Despite reductions in the number of maternal deaths-from about 376000 in 1990 to about 293000 in 2013-only 16 countries, seven of which are developing countries, are expected to achieve the MDG 5 target of a 75\% reduction in the MMR by 2015 . We noted two different patterns in developing countries: sustained substantial decreases in most of Asia and Latin America, and stagnation or increases from 1990 to 2003 in sub-Saharan Africa and Oceania. Increases in some high-income countries such as the USA are a deviation from the general trend downwards in developed countries. However, the substantial acceleration in the decreases since 2003-especially in sub-Saharan Africa-provides hope that more countries can achieve rapid and sustained reductions.

Ambitious calls for progress in maternal mortality in the next 15-20 years and reductions in MMRs to less than 30 in all countries have been deemed financially and technically feasible. ${ }^{48}$ Our finding that rates of change in maternal mortality in some developing countries have exceeded $8 \%$ in the past decade (eg, in China) lends support to ambitious aspirational goals. However, on the accelerated trajectory from 2003 to 2013, MMRs will still be high in several countries in west and central Africa, and in the Horn of Africa. Unsurprisingly, projections for child mortality in 2030 are also high in these areas of the world. A focus on levels of maternal mortality equivalent to those in high-income nations in all countries will need special policy attention, national action, and global investment in the countries that are predicted to be left far behind a grand convergence. Many of the countries in central and west Africa that will present the greatest challenge to achievement of low MMRs have historically received less development assistance for health than have other low-income countries. ${ }^{49}$ Although development assistance for maternal, newborn, and child health has been increasing at a pace faster than that for most thematic areas, excluding HIV, especially since 2009, increases in central and west Africa have not been as large as in other regions. A new focus on these countries will probably need action by multilateral, bilateral, and private global health funders, and shifts in the historical allocation of funds across low-income countries.

The drivers of improvement (or lack thereof) in underlying causes of maternal deaths have important clinical, public health, and policy implications. Maternal mortality has been successfully reduced in many countries. Although the absolute numbers of deaths due to abortion, maternal haemorrhage, and hypertensive disorders of pregnancy have decreased in real terms, these causes remain important, collectively accounting for nearly $50 \%$ of all deaths. Continued promotion of policies to reduce anaemia and malnutrition, prevent malaria in pregnancy, provide calcium and micronutrient supplementation, encourage skilled birth attendance and in-facility delivery, discourage early motherhood, and reduce unsafe abortion should lead to sustained dividends. ${ }^{50-52}$ Such focus should be expected to reduce the risk of life-threatening complications of pregnancy, but the complications will not be eliminated altogether. Increased coverage of skilled birth attendance and delivery in facilities properly resourced for emergency obstetric care is essential for prevention of these deaths.

Health-system re-engineering is necessary to begin preparations for the new challenges that lie ahead. The increasing relative importance of other direct, indirect, and late maternal causes of death is consistent with global epidemiological transition, and suggests that many health systems are inadequate to meet the needs of an increasing number of pregnant women with pre-existing conditions and high-risk pregnancies. The risks of sepsis-related deaths are known to be increased by the prevalence of obesity and diabetes in women of reproductive age. ${ }^{53}$ Moreover, because of the inherent difficulty in diagnosis of maternal sepsis, the problem could be larger than we have estimated in countries with high overall maternal mortality. Therefore, prevention of sepsis will need not only a focus on medical management of comorbidities, but also improved sanitation and access to routine prophylactic antibiotics during caesarean section for facilities that intend to provide such a service, both of which have been shown to be effective and cost-effective strategies to reduce maternal death. ${ }^{54,55}$

Many diseases - eg, sickle-cell anaemia, obesity, diabetes, hypertension, and chronic kidney conditions-confer increased mortality risk during pregnancy. These indirect causes of maternal death are likely to continue increasing in importance where they are commonly encountered. ${ }^{56-60}$ A focus on health-system strengthening will be needed to reduce the effect of other direct causes of maternal death, because the most likely underlying aetiologies are complications of anaesthesia, embolism (air, amniotic fluid, and blood clot), and the less common but often fatal condition of peripartum cardiomyopathy. ${ }^{61-64}$ Health systems must begin to plan for these changes through increasing the size and training of the perioperative workforce and investment in family planning services, adequate infrastructural resources for facilities, and systems to identify and follow women who are at risk of life-threatening puerperial and postpartum complications.

In 2013, HIV accounted for $1.5 \%$ of maternal deaths in sub-Saharan Africa, rising to $6 \cdot 2 \%$ in southern subSaharan Africa. However, HIV infection is associated with the smallest number of deaths worldwide of any of the causes we examined. Increased ART coverage has led to reduced HIV-related mortality in sub-Saharan Africa and
Agency for the Prevention of Blindness and Vision 2020 Weston, FL, USA (VCLansingh PhD); Korea University, Seoul, South Korea (Prof J-T Lee PhD, S-J Yoon PhD); University at Albany, Rensselaer, NY, USA (R Leung PhD); National Centre for Birth Defects Monitoring of China, Chengdu, China (X Li MD); National Centre for Chronic and Non-Communicable Disease Control and Prevention (Yichong Li MPH, S Liu PhD, J Ma PhD, Prof LWang MD, Prof M Zhou PhD), Nationa Institute of Occupational Health and Poison Control (Prof F Tan MD), Chinese Centre for Disease Control and Prevention, Beijing, China (X Liang PhD); Genentech, South San Francisco, CA, USA (Yongmei Li PhD); National Office for Maternal and Child Health Surveillance, West China Second University Hospital, Sichuan University, Chengdu, China (Prof) Liang MD ProfYWang MS, Prof J Zhu MD); Wayne State University, Miami, FL, USA (SE Lipshultz MD); National Institute of Environmental Health Sciences, Research Triangle Park, NC, USA (S) London MD); Ministry of Health Singapore, Singapore, Singapore (S Ma PhD); Xpharmconsult, Kumasi, Ghana (N K Mainoo MMRCB); Department of Public Health, Faculty of Health Sciences and Social Work, Trnava University, Trnava, Slovakia (M Majdan PhD); University of Zambia, Lusaka, Zambia (CC Mapoma PhD) Queen Mary University of London, London, UK (ProfW Marcenes PhD); University of the East Ramon Magsaysay Memorial Medica Centre, Quezon City, Philippines (M B Marzan MSPH); University of York, York, UK

(A) Mason-Jones PhD); Janakpuri Super Specialty Hospital, New Delhi, India (Prof M M Mehndiratta MD); UN Population Fund, Lima, Peru (W Mendoza MD); Pacific Institute for Research and Evaluation, Calverton, MD, USA (T R Miller PhD); University of Ottawa, Ottawa, ON, Canada (EJ Mills PhD); University of Papua New Guinea, Port Moresby, Papua New Guinea (Prof G L Mola MD); Institute for Maternal and Child Health Istituto di Ricovero e Cura a 
Carattere Scientifico Burlo Garofolo, Trieste, Italy (L Monasta DSc, L Ronfani PhD); Bureau of International Health Cooperation, Manila City, Philippines (J de la Cruz Monis MSc); University of North Texas, Denton, TX, USA (Prof A R Moore PhD); Iran University of Medical Sciences,

Department of Community Medicine, Tehran, Iran (M Moradi-Lakeh); National Centre for Child Health and Development, Setagaya, Tokyo, Japan (R Mori PhD):

Philipps-University Marburg, Marburg, Germany (Prof U O Mueller PhD,

RWesterman PhD); Tokyo Medical and Dental University, Tokyo, Japan

(M Mukaigawara MD); International Centre for Diarrhoeal Diseases Research, Dhaka, Bangladesh (A Naheed PhD); University of KwaZulu-Natal, Durban, South Africa (Prof K S Naidoo PhD); Ministry of Health Fiji, Suva, Fiji

(D Nand MPH); Suraj Eye Institute, Nagpur, India (Prof V Nangia MD); School of Public Health, City University of New York, New York, NY, USA (D Nash PhD); Faculty of Medicine, Fez, Morocco (Prof C Nejjari PhD); National Institute of Diabetes and Digestive and Kidney Diseases, Phoenix, AZ, USA (R G Nelson PhD); Norwegian Centre for Addiction Research (SERAF), University of Oslo, Oslo,

Norway (SP Neupane MBBS); Kenya Medical Research Institute Wellcome Trust Programme, Kilifi, Kenya (Prof C R Newton MD); Centre for Research in Environmental Epidemiology (CREAL), Barcelona, Spain

(M J Nieuwenhuijsen PhD); University of Bergen, Bergen, Norway (Prof O F Norheim PhD);

Kyung Hee Unversity, Seoul, South Korea (I-H Oh PhD); Teikyo University School of Medicine, Tokyo, Japan (ProfT Ohkubo MD); Centre for Healthy Start Initiative, Lagos, Nigeria (B O Olusanya PhD); Lira District Local Government, Lira Municipal Council, Lira, Uganda (J N Opio MPH); Toxicology Unit, Faculty of Pharmacy, University of Port Harcourt, Port Harcourt, Nigeria (Prof O E Orisakwe PhD); Christian Medical College Ludhiana, Ludhiana, India has been associated with decreased mortality in HIVpositive women during pregnancy. ${ }^{45,65}$ Nevertheless, the increase in maternal mortality during the mid-2000s in southern Africa is well in excess of the number of HIVassociated maternal deaths. There are at least four possible explanations for this finding. First, we could have underestimated the RR of death for a pregnant woman with HIV infection compared with a pregnant woman without HIV infection. Our meta-analysis results are consistent with previous studies, but the RR could be biased downwards if included studies are from areas with better care or access to ART. ${ }^{22,34}$ Second, we could have overestimated maternal mortality if the UNAIDS Spectrum estimates of HIV prevalence in pregnancy are underestimates. These values suggest that age-specific fertility rates decrease by $24 \%$ in HIV-positive women compared with HIV-negative women when aged 20-24 years, but fertility decreases by $56 \%$ by age 45-49 years. ${ }^{66}$ Third, we assume the RR is generalisable across different levels of HIV prevalence in pregnant women, which might not be true. Fourth, the HIV epidemic could be diverting resources from maternal care because of a huge demand for care. Although this situation is theoretically possible, several studies and reports have not shown this relation; indeed, there could be synergies between ART scale-up and clinic and hospital productivity. ${ }^{67}$ Perhaps the most important finding is that with the scale-up of ART, MMR seems to decrease rapidly (eg, in Malawi). ${ }^{68}$

In our study, we have not tested the association between development assistance for maternal health programmes and MMR. However, accelerated decreases occurred in

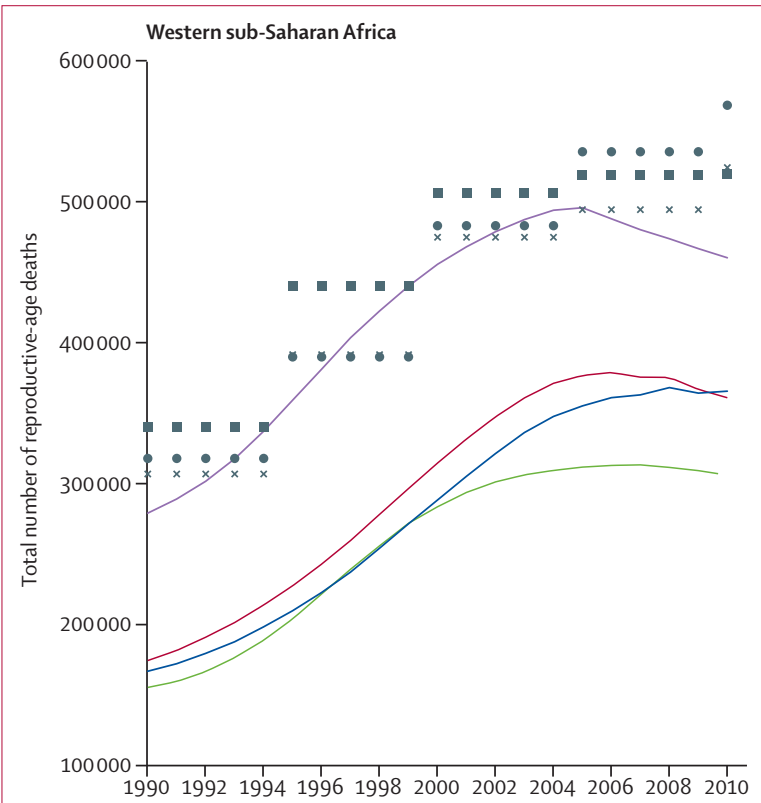

Year
106 of 138 developing countries in 2003-3 years after the Millennium Declaration-coinciding with the scaleup of development assistance for maternal and child health programmes.$^{49}$ Rigorous testing of the hypothesis that global priority setting and investments in maternal health programmes have had an important role in the acceleration of progress is needed. This research is important because it could strengthen the basis on which post-2015 requests for funding of continued expansion of maternal health services are made. Because we have reported much slower rates of change than the UN has, the importance of establishing the case for continued investment in maternal health programmes is even greater; ambitious goals for regions such as sub-Saharan Africa will probably need major investments.

We compared our estimates of maternal mortality with those from the GBD 2010 and the 2012 UN estimates. ${ }^{6}$ The correlation between our MMR estimates and those of GBD 2010 for 1990 was 0 . 96, and for 2010 was $0 \cdot 89$. The correlation figures with the UN analysis for the same two periods were 0.88 and $0 \cdot 85$. Perhaps the most notable difference between the UN 2012 analysis and ours is the number of maternal deaths in 1990: 543000 compared with 376000 . The difference in numbers for 2010 is smaller: 287000 deaths compared with 317300 . The much higher number from the UN for 1990 raises the estimated annualised rate of change in the MMR from 1990 to 2010 substantially, to -3.1\% per year compared with $-1 \cdot 1 \%$ per year in our study. One of the most important differences between our assessment and the UN's seems to be related to the WHO estimates of reproductive-age mortality in some

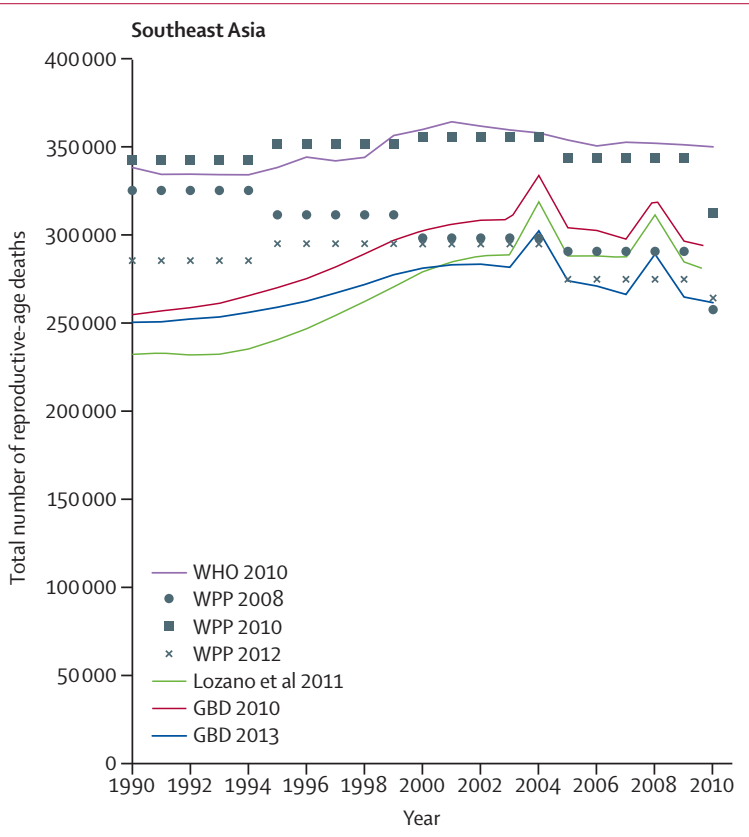

Figure 10: Comparison of all-cause reproductive-age mortality envelopes between 1990 and 2010 WPP $=$ World Population Prospects. GBD=Global Burden of Disease Study. 
regions with high fractions of reproductive-age mortality due to maternal causes. These estimates are substantially higher than the GBD 2013 estimates for west Africa, north Africa and the Middle East, and southeast Asia in 1990, ranging from 7\% higher in Ghana to $58 \%$ higher in Nigeria. The differences between estimates of reproductive-age mortality in western sub-Saharan Africa and southeast Asia are large (figure 10). In some cases, the most recent UN Population Division estimates (World Population Prospects 2012) converge towards the GBD estimates, although WHO estimates are substantially higher (figure 10). The UN Population Division and WHO almost exclusively predict levels of adult mortality in west Africa on the basis of child mortality, whereas we make substantial use of survey and census data from the region in our GBD analysis. ${ }^{69}$ The reasons for the changes between successive revisions of maternal mortality estimates depend on the country, but are driven both by new data for levels of reproductive-age mortality and maternal causes or the fraction of deaths that are related to pregnancy.

Our study, which brings together a wide array of data sources for the levels, causes, and timing of maternal deaths for many countries, has important limitations. First, although ICD-coded vital registration systems have clear rules for assignment of causes of death, we used census and survey data for the fraction of deaths to distinguish explicitly between deaths caused by pregnancy (maternal deaths) and those that were incidental (pregnancy-related deaths). We made adjustments for incidental deaths related to HIV, but have not made similar adjustments for other types of incidental deaths due to causes such as injuries. Studies ${ }^{70,71}$ suggest that deaths due to injury are less common in non-pregnant women than in pregnant women of the same age, but they do occur in both groups, which leads to a bias upwards in our assessment. That bias must be tempered with the potential bias that sibling and household reports of pregnancy-related deaths could lead to selective under-reporting of abortion-related deaths. ${ }^{72}$ Second, uncertainty in the estimates of maternal death in many countries is substantial. ${ }^{73}$ Within the same country, sources can differ widely. For example, we used many different types of sources in India: in rural regions, data are largely from the Survey of Causes of Death-Rural, the Sample Registration System, and verbal autopsy studies, whereas Medical Certification of Causes of Death covers largely urban populations. ${ }^{4}$

Third, there is still no definitive way to estimate the interaction of HIV and pregnancy in death. Only 21 studies were available for estimation of the excess risk of death during pregnancy in women with HIV. Only two studies ${ }^{44,45}$ inform the excess risk of death during pregnancy in women with HIV. These two studies provide widely divergent findings and could reflect the complex interaction between ART (and the associated greater care received by women taking it) and pregnancy as much as the effect of pregnancy on the progression of HIV. As such data continue to be developed and because of the important implications for policy making, we will continue to work to find new data sources, improve data quality, and incorporate updated methods as necessary to continue providing updates for global, regional, and national maternal mortality.

Fourth, because of sparse data, we could not quantify the contributions of other infections, such as influenza (eg, H1N1), malaria, tuberculosis, and hepatitis, to maternal mortality at the population level. ${ }^{74}$ Fifth, our method of estimating the detailed causes of maternal death used all available data, but such specific data are not available for many countries, or, if they are available, are coarse with respect to age. Therefore, we might have underestimated the true extent of the interplay between cause and age in maternal mortality and differences between countries in the same region.

Sixth, we have estimated UIs for each component of the analysis. CODEm provides confirmation that the UIs for the maternal mortality model have a data coverage of $97.9 \%$, so they could be slightly overestimated. Finally, our estimates of maternal mortality are affected by estimates in each age group of other causes of death developed for the GBD 2013 because of the requirement that cause-specific mortality must sum to all-cause
(JD Pandian MD);

Sungkyunkwan University School of Medicine, Suwon, South Korea (ProfJ-H Park MPH); Universidad de Cartagena, Cartagena, Colombia

(A) Paternina Caicedo MSc); University of Calgary, Calgary, AB, Canada (Prof S B Patten PhD); All India Institute of Medical Sciences (AlIMS), New Delhi, India (Prof V K Paul MD); WHO Waigani, Papua New Guinea (B I Pavlin MD); London School of Hygiene \& Tropical Medicine, London, UK (Prof N Pearce PhD); 3B's Research Group in Biomaterials, Biodegradables and Biomimetics, University of Minho, Headquarters of the European Institute of Excellence on Tissue Engineering and Regenerative Medicine, and ICVS/3B's PT Government Associate Laboratory, Braga Portugal (Prof D M Pereira PhD); Flinders University, Adelaide, SA, Australia (Prof K Pesudovs PhD); Centre for Applied Biostatistics, Sahlgrenska Academy, University of Gothenburg Sweden (Prof M Petzold PhD) McMaster University, Hamilton, ON, Canada (D Poenaru MD) Erasmus Medical Center

\section{Panel: Research in context}

Our analysis continues a body of analytical work into levels and trends in maternal mortality that began with Hogan and colleagues' report ${ }^{4}$ and was followed by that by Lozano and colleagues ${ }^{5}$ and the Global Burden of Disease Study 2010 (GBD 2010). ${ }^{16}$ With each subsequent study, there have been important advances in the data available for analysis and the methods of analysis. Lozano and colleagues ${ }^{5}$ moved from one preferred regression model, as used by Hogan and colleagues and the UN measurement efforts, ${ }^{6,20}$ to an ensemble of multiple models developed through rigorous out-of-sample predictive validity testing. The maternal mortality analysis included in GBD 2010 extended the analysis in two important ways: maternal mortality was assessed with all other causes of death subject to the constraint that sum of individual causes of death equalled the demographic assessment of all-cause mortality in each age group of reproductive-age women, and it included estimates of the major causes of maternal mortality. In our study, in addition to 2421 site-years of new data, several important methodological innovations improve the estimation of maternal mortality. First, we have analysed sibling history data for the fraction of reproductive-age deaths that are related to pregnancy by calendar year for each 5-year age group of mothers, pooling data from several surveys when events for the same calendar year were recorded. Second, we have substantially revised the approach to understand the effect of HIV on maternal mortality. We did a systematic review and used relative risks from cohort studies to accurately assign a fairly small fraction of HIVrelated deaths during pregnancy or the puerperium to be maternal deaths. Third, we have quantified other direct maternal causes, indirect maternal causes, and late maternal death for the first time. Fourth, we have analysed previous reports and other sources about the timing of maternal deaths to provide guidance on when most deaths occur. Our data and improved methods have led to a different understanding of the evolution of global maternal deaths with important implications for target setting in the post-MDG era. 
Department of Public Health, Rotterdam, Netherlands (S Polinder PhD); University of Liverpool, Liverpool, UK (D Pope PhD); University of British Columbia, Vancouver, BC, Canada (F Pourmalek PhD); College of Pharmacy (D Qato PhD), University of Illinois, Chicago, IL, USA (K M Tabb PhD); Contech International, Lahore, Pakistan (A Rafay MS); Hamad Medical Corporation, Doha, Qatar (Sur Rahman FRCPCH); University of Missouri, Columbia, MO, USA

(M Raju PhD); Department of Public Health, University of the Punjab, Lahore, Pakistan (S M Rana PhD); Walden University, Minneapolis, MN, USA (Prof A Refaat PhD); Bhaba Atomic Research Center Hospital, Mumbai, India (N Roy MD); Marshall University, Huntington, WV, USA (M Sawhney PhD); Federal University of Santa Catarina, Florianópolis, Brazil (IJ C Schneider PhD); University of Alabama at Birmingham, Birmingham, AL, USA (D C Schwebel PhD, J A Singh MD); Stellenbosch University, Cape Town, South Africa

(Prof S Seedat PhD); Health Canada, Ottawa, ON, Canada (H H Shin PhD,

SWeichenthal PhD); Heriot-Watt

University, Edinburgh, UK

(I Shive PhD); Reykjavik University, Reykjavik, Iceland (ID Sigfusdottir PhD); University

of Pennsylvania, Philadelphia, PA, USA (Prof D H Silberberg MD); Instituto Nacional de Epidemiología Dr Juan H Jara, Mar del Plata, Buenos Aires,

Argentina (A P Silva MgSc); Norwegian Institute of Public

Health, Oslo, Norway (ProfV Skirbekk PhD); Federal Research Institute for Health Organisation and Informatics of Ministry of Health of the Russian

Federation, Moscow, Russia (S S Soshnikov PhD); Department of Clinical Neurological Sciences, Western University, London, ON Canada (LA Sposato MD); University Tunku Abdul Rahman, Kajang, Malaysia (CT Sreeramareddy MD); Hellenic Centre for Disease Control and Prevention (KEELPNO) Greece, Athens, Greece (K Stroumpoulis PhD); Department of Criminology, Law and Society (and Sociology), University of California Irvine, Irvine, CA, USA (B L Sykes PhD); mortality. Errors in the estimates for other causes of death could bias upwards or downwards our assessments of maternal mortality.

An important part of improved measurement in the future is a recommendation that surveillance of late maternal mortality ( $>42$ days but $<1$ year) be included in surveys and censuses. With the assumption that maternal mortality will continue to decrease, severe maternal morbidity or so-called near miss cases are likely to increase, some of which might be expected to lead to increased late maternal death. ${ }^{54}$ Perhaps more importantly for some regions, HIV has been described by some as being a risk factor for late maternal death. If this description is true, these deaths might not be captured appropriately, because neither reproductive health surveys nor demographic and health surveys quantify late maternal death. In view of the major dependency on sibling histories and the recall of pregnancy-related deaths in household surveys, major changes would be necessary to track late maternal deaths through these instruments.

Measurement of maternal mortality remains challenging (panel). It depends both on robust demographic assessment of reproductive-age mortality rates and data for the fraction of deaths in each age group that are maternal or related to pregnancy. Changes between systematic analyses in the levels and trends in maternal mortality are larger than for child mortality. As a result, users of any assessment of maternal mortality need to recognise that assessments could change as new data are identified or obtained. Despite continuing measurement challenges, there are strong reasons to continue a global focus on reductions in maternal death in the next 15-20 years. An important adjunct to both the framing of new goals and mobilisation of action for them will be regular updates about the evidence in the trends for maternal mortality by age, cause, and timing. We believe that it is this evidence that should fuel and inspire debates and policies to reduce maternal deaths. We believe the evidence is convincing that decreases in the MMR have accelerated in several countries since 2003. These accelerations should be carefully studied to provide qualitative insights into what has worked in different settings. As new global targets for maternal mortality are developed, it will be important to take lessons from these insights, but also begin planning for the evolving health and health-care needs of women of reproductive age. Achievement (or not) of arbitrary goals established without proper regard to the distribution of rates of change prevailing at the time is a political construct that obscures knowledge and praise for the substantial progress that has been made to reduce maternal mortality in the past decade. Furthermore accelerated decreases in maternal mortality will be more likely if the evidence from policy responses in these countries is widely and effectively disseminated and implemented.

\section{Contributors}

NJK and CJLM prepared the first draft. NJK, CS, ADL, CJLM, and RL finalised the draft on the basis of comments from other authors and reviewer feedback. NJK, ADL, CJLM, and RL conceived the study and provided overall guidance. NJK completed all modelling. NJK, AB-V, and MSC did the statistical analysis of model results. All other authors provided data, developed models, reviewed results, initiated modelling infrastructure, and reviewed the report.

\section{Declaration of interests}

Cyrus Cooper has received consultancy fees, lecture fees, and honoraria from Amgen, GlaxoSmithKline, Alliance for Better Bone Health, Merck Sharp and Dohme, Eli Lilly, Pfizer, Novartis, Servier, Medtronic, and Roche. Katherine B Gibney received the National Health and Medical Research Council Gustav Nossal scholarship sponsored by CSL in 2012; this award is peer-reviewed through the standard National Health and Medical Research Countil peer-review process, and CSL does not play any part in selection of the awardee. Norito Kawakami has received fees from Meiji, Otsuka, EAP Consulting, Fujitsu Software Technologies, Japan Productivity Center, Occupational Health Foundation, Japan Housing Finance Agency, Aishin-Seiki, and the Japan Dental Association; consultancy fees from Sekisui Chemicals, Junpukai Health Care Center, and Osaka Chamber of Commerce and Industry; and royalties from Igaku-Shoin, Taisha-kan, Nanko-do, Nanzan-do, PHP Publication, and Fujitsu Software Technologies. Norito Kawakami has also received research grants from the Japanese Ministry of Education, Science, and Technology; the Japanese Ministry of Health, Labor and Welfare; Fujitsu Software Technologies; Softbank; and Japan Management Association. Guilherme V Polanczyk has received grants or research support from the National Council for Scientific and Technological Development, the São Paulo Research Foundation, and the University of São Paulo; has served as a paid consultant to Shire; has served on the speakers' bureau of Shire; and has received royalties from Editora Manole. Jasvinder A Singh has received research grants from Takeda and Savient; has received consultant fees from Savient, Takeda, Regeneron, and Allergan; is a member of the executive of OMERACT, an organisation that develops outcome measures in rheumatology and receives arms-length funding from 36 companies; is a member of the American College of Rheumatology's Guidelines Subcommittee of the Quality of Care Committee; and is a member of the Veterans Affairs Rheumatology Field Advisory Committee. The other authors declare no competing interests.

\section{Acknowledgments}

We thank the countless individuals who have contributed to the Global Burden of Disease Study 2013 in various capacities. We would like to acknowledge the extensive support from all staff members at the Institute for Health Metrics and Evaluation and specifically thank: Michael F MacIntyre, Peter Speyer, and Summer Lockett Ohno for their management of the Global Burden of Disease Study 2013; Kelsey Pierce for her valuable guidance; Peter Speyer, James Bullard, Serkan Yalcin, Edgar Sioson, Evan Laurie, Charles Atkinson, and Andrew Ernst for their tireless support of the computational infrastructure necessary to produce the results; Linda A Ettinger for her expert administrative support; Peter Speyer, Abigail McLain, Marissa Iannarone, and Eden Stork for their persistent and invaluable work to gain access to and catalogue as much data as possible to inform the estimates; Emily A Dansereau, D Allen Roberts, Katrina Ortblad, Herbert C Duber, Elizabeth K Johnson, and Jonathan C Brown for their efforts in developing and improving the HIV modeling process; Nicholas Graetz for computational support; Madeline L Moyer, Bryan K Phillips, Lee Richardson, Logan Sandar, and Stan Biryukov for data extraction and processing; Christopher Margono for assistance with referencing and submission; Thomas D Fleming for covariates and literature references support; and Meghan D Mooney for coordination of all-cause mortality estimates. No individuals acknowledged received additional compensation for their efforts.

\section{References}

1 Shiffman J, Smith S. Generation of political priority for global health initiatives: a framework and case study of maternal mortality. Lancet 2007; 370: 1370-79. 
2 Bustreo F, Requejo JH, Merialdi M, Presern C, Songane F. From safe motherhood, newborn, and child survival partnerships to the continuum of care and accountability: moving fast forward to 2015. Int J Gynaecol Obstet 2012; 119 (suppl 1): S6-8.

3 Commission on Information and Accountability for Women's and Children's Health. Keeping promises, measuring results. 2011. http://www.everywomaneverychild.org/images/content/files/ accountability_commission/final_report/Final_EN_Web.pdf (accessed January 29, 2014).

4 Hogan MC, Foreman KJ, Naghavi M, et al. Maternal mortality for 181 countries, 1980-2008: a systematic analysis of progress towards Millennium Development Goal 5. Lancet 2010; 375: 1609-23.

5 Lozano R, Wang H, Foreman KJ, et al. Progress towards Millennium Development Goals 4 and 5 on maternal and child mortality: an updated systematic analysis. Lancet 2011; 378: 1139-65.

6 WHO, UNICEF, UN Population Fund, World Bank. Trends in maternal mortality: 1990 to 2010. 2012. http://www.unfpa.org/ webdav/site/global/shared/documents/publications/2012/Trends_ in_maternal_mortality_A4-1.pdf (accessed Jan 31, 2014).

7 Bhutta ZA, Chopra M, Axelson H, et al. Countdown to 2015 decade report (2000-10): taking stock of maternal, newborn, and child survival. Lancet 2010; 375: 2032-44.

8 Hounton S, De Bernis L, Hussein J, et al. Towards elimination of maternal deaths: maternal deaths surveillance and response. Reprod Health 2013; 10: 1.

9 Leone T. Measuring differential maternal mortality using census data in developing countries. Popul Space Place 2013; published online July 8. DOI:10.1002/psp.1802.

10 Helleringer S, Duthé G, Kanté AM, et al. Misclassification of pregnancy-related deaths in adult mortality surveys: case study in Senegal. Trop Med Int Health 2013; 18: 27-34.

11 Cross S, Bell JS, Graham WJ. What you count is what you target: the implications of maternal death classification for tracking progress towards reducing maternal mortality in developing countries. Bull World Health Organ 2010; 88: 147-53.

12 Lawson GW, Keirse MJNC. Reflections on the maternal mortality Millennium Goal. Birth 2013; 40: 96-102.

13 Mangham LJ, Hanson K. Scaling up in international health: what are the key issues? Health Policy Plan 2010; 25: 85-96.

14 Naghavi M, Makela S, Foreman K, O’Brien J, Pourmalek F, Lozano R. Algorithms for enhancing public health utility of national causes-of-death data. Popul Health Metr 2010; 8: 9.

15 Naghavi M, Wang H, Vos T, et al. Global, regional, and national levels of age-specific mortality and 239 causes of death during 1990-2013: a systematic analysis for the Global Burden of Disease Study 2013. Lancet (submitted).

16 Lozano R, Naghavi M, Foreman K, et al. Global and regional mortality from 235 causes of death for 20 age groups in 1990 and 2010: a systematic analysis for the Global Burden of Disease Study 2010. Lancet 2012; 380: 2095-128.

17 WHO. International statistical classification of diseases and related health problems: tenth revision, volume 2. 2004. http://www.who. int/classifications/icd/ICD-10_2nd_ed_volume2.pdf (accessed Feb 3, 2014).

18 Confidential Enquiry into Maternal and Child Health. Why mothers die: 2000-2002. London: Royal College of Obstetricians and Gynaecologists Press, 2004.

19 Ronsmans C, Graham WJ, on behalf of The Lancet Maternal Survival Series steering group. Maternal mortality: who, when, where, and why. Lancet 2006; 368: 1189-200.

20 UN Development Group. Indicators for monitoring the Millennium Development Goals: definitions, rationale, concepts, and sources. 2003. http://www.undp.org/content/dam/aplaws/publication/en/ publications/poverty-reduction/poverty-website/indicators-formonitoring-the-mdgs/Indicators_for_Monitoring_the_MDGs.pdf (accessed Feb 1, 2014).

21 Gakidou E, King G. Death by survey: estimating adult mortality without selection bias from sibling survival data. Demography 2006; 43: 569-85.

22 Calvert C, Ronsmans C. The contribution of HIV to pregnancy-related mortality: a systematic review and meta-analysis. AIDS 2013; 27: 1631-39.
23 Le Coeur S, Khlat M, Halembokaka G, et al. HIV and the magnitude of pregnancy-related mortality in Pointe Noire, Congo. AIDS 2005; 19: 69-75.

24 Lionel J, Aleyamma TK, Varghese L, et al. HIV and obstetric complications and fetal outcomes in Vellore, India. Trop Doct 2008; 38: $144-46$

25 Louis J, Landon MB, Gersnoviez RJ, et al. Perioperative morbidity and mortality among human immunodeficiency virus infected women undergoing cesarean delivery. Obstet Gynecol 2007; 110: 385-90.

26 Kourtis AP, Bansil P, McPheeters M, Meikle SF, Posner SF, Jamieson DJ. Hospitalizations of pregnant HIV-infected women in the USA prior to and during the era of HAART, 1994-2003. AIDS 2006; 20: 1823-31.

27 Khan M, Pillay T, Moodley JM, Connolly CA, for the Durban Perinatal TB HIV-1 Study Group. Maternal mortality associated with tuberculosis-HIV-1 co-infection in Durban, South Africa. AIDS 2001; 15: 1857-63.

28 De Groot MR, Corporaal LJ, Cronjé HS, Joubert G. HIV infection in critically ill obstetrical patients. Int J Gynaecol Obstet 2003; 81: 9-16.

29 Coley JL, Msamanga GI, Fawzi MC, et al. The association between maternal HIV-1 infection and pregnancy outcomes in Dar es Salaam, Tanzania. BJOG 2001; 108: 1125-33.

30 Zvandasara P, Hargrove JW, Ntozini R, et al. Mortality and morbidity among postpartum HIV-positive and HIV-negative women in Zimbabwe: risk factors, causes, and impact of single-dose postpartum vitamin A supplementation. J Acquir Immune Defic Syndr 2006; 43: 107-16.

31 Sewankambo NK, Gray RH, Ahmad S, et al. Mortality associated with HIV infection in rural Rakai District, Uganda. AIDS 2000; 14: 2391-400.

32 McDermott JM, Slutsker L, Steketee RW, Wirima JJ, Breman JG, Heymann DL. Prospective assessment of mortality among a cohort of pregnant women in rural Malawi. Am J Trop Med Hyg 1996; 55: 66-70.

33 Black V, Brooke $\mathrm{S}$, Chersich MF. Effect of human immunodeficiency virus treatment on maternal mortality at a tertiary center in South Africa: a 5-year audit. Obstet Gynecol 2009; 114: 292-99.

34 Zaba B, Calvert C, Marston M, et al. Effect of HIV infection on pregnancy-related mortality in sub-Saharan Africa: secondary analyses of pooled community-based data from the network for Analysing Longitudinal Population-based HIV/AIDS data on Africa (ALPHA). Lancet 2013; 381: 1763-71.

35 Mmiro F, Ndugwa C, Guay L, et al. Effect of human immunodeficiency virus-1 infection on the outcome of pregnancy in Ugandan women. Pediatr AIDS HIV Infect 1993; 4: 67-73.

36 Temmerman M, Chomba EN, Ndinya-Achola J, Plummer FA, Coppens M, Piot P. Maternal human immunodeficiency virus-1 infection and pregnancy outcome. Obstet Gynecol 1994; 83: 495-501.

37 Nathoo K, Rusakaniko S, Zijenah LS, et al. Survival pattern among infants born to human immunodeficiency virus type-1 infected mothers and uninfected mothers in Harare, Zimbabwe. Cent Afr J Med 2004; 50: 1-6.

38 Kumar RM, Uduman SA, Khurranna AK. Impact of maternal HIV-1 infection on perinatal outcome. Int J Gynaecol Obstet 1995; 49: $137-43$

39 Nuwagaba-Biribonwoha H, Mayon-White RT, Okong P, Carpenter LM, Jenkinson C. The impact of HIV on maternal quality of life in Uganda. AIDS Care 2006; 18: 614-20.

40 Maiques-Montesinos V, Cervera-Sanchez J, Bellver-Pradas J, Abad-Carrascosa A, Serra-Serra V. Post-cesarean section morbidity in HIV-positive women. Acta Obstet Gynecol Scand 1999; 78: 789-92.

41 Ryder RW, Nsuami M, Nsa W, et al. Mortality in HIV-1-seropositive women, their spouses and their newly born children during 36 months of follow-up in Kinshasa, Zaïre. AIDS 1994; 8: 667-72.

42 Lepage P, Dabis F, Hitimana DG, et al. Perinatal transmission of HIV-1: lack of impact of maternal HIV infection on characteristics of livebirths and on neonatal mortality in Kigali, Rwanda. AIDS 1991; 5: 295-300.

43 Chilongozi D, Wang L, Brown L, et al. Morbidity and mortality among a cohort of human immunodeficiency virus type 1-infected and uninfected pregnant women and their infants from Malawi, Zambia, and Tanzania. Pediatr Infect Dis J 2008; 27: 808-14.
Ministry of Public Health,

Yaounde, Cameroon (RTTalongwa MD); Memorial University, St John's, NL, Canada (EYTenkorang PhD); Department of Anesthesiology, University of Virginia, Charlottesville, VA, USA (A STerkawi MD); Department of Anesthesiology, King Fahad Medical City, Riyadh, Saudi Arabia (A STerkawi); The Earth Institute, Columbia University, New York, NY, USA (A LThorne-Lyman SCD); Cincinnati Children's Hospital Medical Centre, Cincinnati, $\mathrm{OH}$, USA (Prof J A Towbin MD); Johns Hopkins Bloomberg School of Public Health, Baltimore, MD USA (BXTran PhD); Department of Medicine, University of Crete, Heraklion, Greece (Prof M Tsilimbaris PhD); Department of Veterans Affairs, Washington, DC, USA (U S Uchendu MD); Department of Internal Medicine, Federal Teaching Hospital Abakaliki, Abakaliki, Nigeria (K N Ukwaja MD); National Institute for Public Health and the Environment, Bilthoven, Netherlands (CH van Gool PhD); UKK Institute for Health Promotion Research, Tampere, Finland (ProfT J Vasankari PhD); Neuroscience Centre, Raffles Hospital, Singapore (N Venketasubramanian MD); University of Bologna, Bologna, Italy (Prof F S Violante MD): Higher School of Economics, Moscow, Russia (Prof VV Vlassov MD); Uniformed Services University of Health Sciences, Bethesda, MD, USA (SWaller MD); Shandong University Affiliated Jinan Central Hospital, Jinan, China (XRWang PhD); Murdoch Children's Research Institute Royal Children's Hospital, Melbourne, VIC, Australia (RGWeintraub); University of Miami, Miami, FL, USA (JDWilkinson MD); Institute of Public Health, University of Gondar, Gondar, Ethiopia (SM Woldeyohannes MPH) Ateneo School of Medicine and Public Health, City of Pasig, Manila, Philippines (JQ Wong MD); Jimma University, Jimma, Ethiopia (M A Wordofa MPH); Nanjing University School of Medicine, Jinling Hospital, Nanjing, China (Prof G Xu PhD); University of North Carolina at Chapel Hill, Chapel Hill, NC, USA 


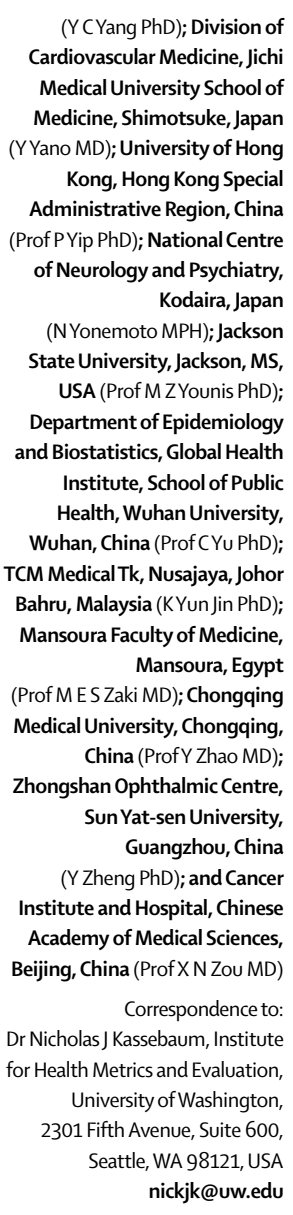

See Online for appendix
44 Matthews LT, Kaida A, Kanters S, et al. HIV-infected women on antiretroviral treatment have increased mortality during pregnant and postpartum periods. AIDS 2013; 27 (suppl 1): S105-112.

45 Westreich D, Maskew M, Evans D, Firnhaber C, Majuba P, Sanne I. Incident pregnancy and time to death or AIDS among HIV-positive women receiving antiretroviral therapy. PloS One 2013; 8: e58117.

46 Foreman KJ, Lozano R, Lopez AD, Murray CJ. Modeling causes of death: an integrated approach using CODEm. Popul Health Metr 2012; 10: 1 .

47 Romano M, Cacciatore A, Giordano R, La Rosa B. Postpartum period: three distinct but continuous phases. J Prenat Med 2010; 4: 22-25.

48 Jamison DT, Summers LH, Alleyne G, et al. Global health 2035: a world converging within a generation. Lancet 2013; 382: 1898-955.

49 Institute for Health Metrics and Evaluation. Financing global health 2013: transition in an age of austerity. Seattle, WA: Institute for Health Metrics and Evaluation, 2014.

50 Konje JC, Ladipo OA. Nutrition and obstructed labor. Am J Clin Nutr 2000; 72 (suppl 1): 291-97S.

51 Bhutta ZA, Das JK, Rizvi A, et al. Evidence-based interventions for improvement of maternal and child nutrition: what can be done and at what cost? Lancet 2013; 382: 452-77.

52 Bhutta ZA, Ahmed T, Black RE, et al. What works? Interventions for maternal and child undernutrition and survival. Lancet 2008; 371: 417-40.

53 Acosta C, Bhattacharya S, Tuffnell D, Kurinczuk J, Knight M. Maternal sepsis: a Scottish population-based case-control study. BJOG 2012; 119: 474-83.

54 Say L, Pattinson RC, Gülmezoglu AM. WHO systematic review of maternal morbidity and mortality: the prevalence of severe acute maternal morbidity (near miss). Reprod Health 2004; 1: 3.

55 Morgan J, Roberts S. Maternal sepsis. Obstet Gynecol Clin North Am 2013; 40: 69-87.

56 Asnani MR, McCaw-Binns AM, Reid ME. Excess risk of maternal death from sickle cell disease in Jamaica: 1998-2007. PloS One 2011; 6: e26281.

57 Wilkinson $\mathrm{H}$, on behalf of the Trustees and Medical Advisers. Saving mothers' lives. Reviewing maternal deaths to make motherhood safer: 2006-2008. BJOG 2011; 118: 1402-03.

58 Rahimy MC, Gangbo A, Adjou R, Deguenon C, Goussanou S, Alihonou E. Effect of active prenatal management on pregnancy outcome in sickle cell disease in an African setting. Blood 2000; 96: $1685-89$.

59 Nevis IF, Reitsma A, Dominic A, et al. Pregnancy outcomes in women with chronic kidney disease: a systematic review. Clin J Am Soc Nephrol 2011; 6: 2587-98.

60 Gilbert WM, Young AL, Danielsen B. Pregnancy outcomes in women with chronic hypertension: a population-based study. J Reprod Med 2007; 52: 1046-51.
61 Brar SS, Khan SS, Sandhu GK, et al. Incidence, mortality, and racial differences in peripartum cardiomyopathy. Am J Cardiol 2007; 100: 302-04.

62 Goland S, Modi K, Bitar F, et al. Clinical profile and predictors of complications in peripartum cardiomyopathy. J Card Fail 2009; 15: 645-50.

63 Sliwa K, Fett J, Elkayam U. Peripartum cardiomyopathy. Lancet 2006; 368: 687-93.

64 Maman AFO-B, Tomta K, Ahouangbévi S, Chobli M. Deaths associated with anaesthesia in Togo, West Africa. Trop Doct 2005; 35: 220-22.

65 The Antiretroviral Therapy in Lower Income Countries (ART-LINC) Collaboration and ART Cohort Collaboration (ART-CC) groups. Mortality of HIV-1-infected patients in the first year of antiretroviral therapy: comparison between low-income and high-income countries. Lancet 2006; 367: 817-24.

66 Murray CJL, Ortblad KF, Guinovart C, et al. Global, regional, and national incidence and death for HIV, tuberculosis, and malaria during 1990-2013: a systematic analysis for the Global Burden of Disease Study 2013. Lancet (submitted).

67 World Health Organization Maximizing Positive Synergies Collaborative Group. An assessment of interactions between global health initiatives and country health systems. Lancet 2009; 373: 2137-69.

68 Colbourn T, Lewycka S, Nambiar B, Anwar I, Phoya A, Mhango C. Maternal mortality in Malawi, 1977-2012. BMJ Open 2013; 3: e004150.

69 Wang H, Dwyer-Lindgren L, Lofgren KT, et al. Age-specific and sex-specific mortality in 187 countries, 1970-2010: a systematic analysis for the Global Burden of Disease Study 2010. Lancet 2012; 380: 2071-94.

70 Yusuf HR, Akhter HH, Rahman MH, Chowdhury ME, Rochat RW. Injury-related deaths among women aged $10-50$ years in Bangladesh, 1996-97. Lancet 2000; 355: 1220-24.

71 Gissler M, Berg C, Bouvier-Colle M-H, Buekens P. Injury deaths, suicides and homicides associated with pregnancy, Finland 1987-2000. Eur J Public Health 2005; 15: 459-63.

72 Shahidullah M. The sisterhood method of estimating maternal mortality: the Matlab experience. Stud Fam Plann 1995; 26: 101-06.

73 Hill K, Thomas K, AbouZahr C, et al. Estimates of maternal mortality worldwide between 1990 and 2005: an assessment of available data. Lancet 2007; 370: 1311-19.

74 Conroy AL, McDonald CR, Kain KC. Malaria in pregnancy: diagnosing infection and identifying fetal risk.

Expert Rev Anti Infect Ther 2012; 10: 1331-42. 